\title{
Luonnontieteellisin analyysimenetelmin tunnistettu Akseli Gallen-Kallelan väripaletti
}

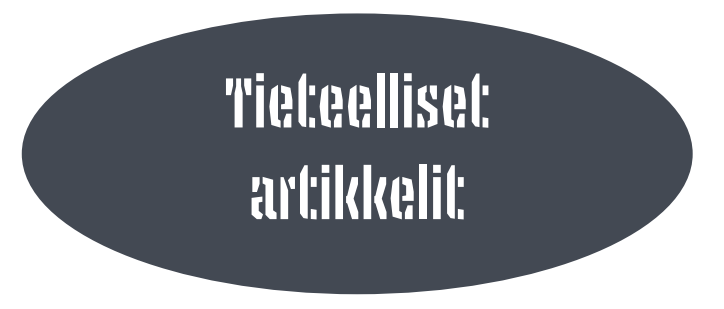

Hanne Tikkala \& Seppo Hornytzkyj

"Preussinsininen väri jota käytin on vähitellen mustunut ja viheriäistynyt"

Tämä artikkeli käsittelee tutkimusta, jossa tunnistettiin Akseli Gallen-Kallelan paletin väriaineita luonnontieteellisiä ja pääasiassa ainetta rikkomattomia analyysimenetelmiä käyttäen. Tutkimusaineisto on läpileikkaus taiteilijan taiteellisesta tuotannosta vuosilta 1880-1929. Se koostuu 265:stä maalauksesta ja 83:sta öljy- ja temperavärituubista. Tutkimus on ensimmäinen laatuaan Suomessa ja se osoittaa, että Gallen-Kallelan paletti sisältää pääosin synteettisiä epäorgaanisia väriaineita. Hänellä on ollut käytössään peruspaletti, jonka väriaineet esiintyvät suurimassa osassa teoksia. Nämä voivat esiintyä teoksen väripinnoilla yksin tai osana
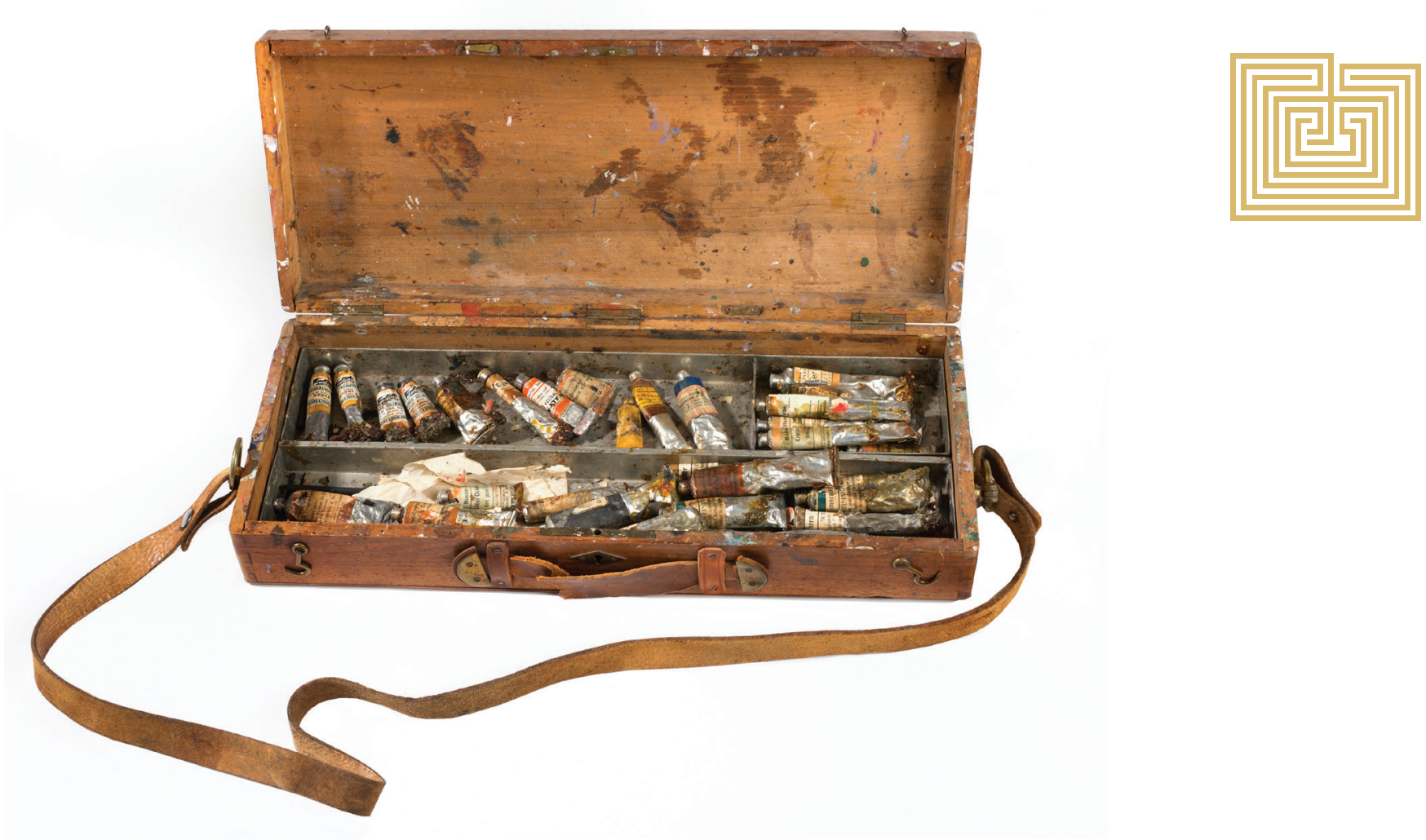

Kuva 1. Akseli Gallen-Kallelan öljyvärituubeja. Omistaja Gallen-Kallelan museo (GKM-898). Kuva: Jenni Nurminen ja Ainur Nasretdin. 
eri väriaineiden seosta. Peruspaletin lisäksi taiteilijalla on ollut käytössään sivupaletti, jonka väriaineet esiintyvät vain osassa teoksista tai niiden käyttö on ajanjaksosidonnaista. Näitä sivupaletin väriaineita esiintyy myös tutkituissa öljy- ja temperavärituubeissa. Edellä mainittujen väriaineryhmien lisäksi on tunnistettu väriaineita, joita esiintyy vain muutamissa teoksissa ja yhdessä väriainetuubissa. Gallen-Kallela on kokeillut näitä, mutta ei ole ottanut niitä omikseen tai vaihtoehtoisesti hän ei ole ollut tietoinen käyttämiensä väriainetuubien sisältämistä väriaineista. Tutkimustulosten perusteella voidaan havaita muutoksia Gallen-Kallelan väriainemieltymyksissä maalaustyylien vaihtuessa, mutta paletti on aina ollut varsin laaja sisältäen vähintään seitsemän erilaista väriaineryhmää: koboltinsininen, erisävyiset rautapitoiset värit, lyijy- ja sinkkivalkoinen, vihreät ja keltaiset kromiyhdisteet, keltainen ja oranssi kadmiumsulfidi sekä punainen sinooperi.

Axel Gallén, myöhemmin Akseli Gallen-Kallela (1865-1931), oli aktiivinen vaikuttaja murroksessa elävän Suomen taidekentällä ja hän sai jo elinaikanaan mainetta Suomen kansallistaiteilijana ja suomalaisen identiteetin rakentajana. Hänen taiteellinen tuotantonsa valikoitui tämän tutkimuksen kohteeksi, koska se on monipuolinen, laaja ja sen väreissä on havaittavissa muutoksia taiteilijan maalaustyylin muuttuessa. Gallen-Kallelan teokset ovat myös usein väärennösten kohteina sekä aikalaisväärentäjien että nykyisten väärentäjien toimesta. Maalaustyyliltään alkutuotannon maalaukset ilmentävät realismia ja romanttista kansankuvausta siirtyen symbolististen Kalevala-aiheiden kautta loppuvaiheen värikkäisiin, jopa ekspressionistisiin teoksiin. Kuten useilla aikalaisillaan, myös Gallen-Kallelan alkutuotannon väriskaala on maanläheinen ja ilmaisu naturalistista. ${ }^{2}$ Väriskaala muuttuu heleämmäksi ja kirkastuu ${ }^{3}$ maalaustekniikan ja maalaamisen tradition muuttuessa ilmaisultaan vapaammaksi ja rohkeammaksi. Gallen-Kallelan väripaletin muuttuminen heleämmäksi osuu 1910-luvulle, erityisesti Afrikan matkaan. ${ }^{4}$ Tällöin myös Euroopan taidekenttä oli murroksessa ja taiteilijat hakivat uusia ilmaisutapoja sekä hehkuvia ja kirkkaita värejä maalauksiinsa. ${ }^{5}$ Gallen-Kallela oli boheemi kosmopoliitti, joka asui ja matkusti myös eri puolilla maailmaa. ${ }^{6}$ Hänen voidaan olettaa hankkineen maalauksiinsa tarvittavia materiaaleja niistä maista, joissa hän vietti aikaansa ja loi uraansa. Tässä tutkimuksessa tutkitut väriainetuubit ovat peräisin saksalaisilta, ranskalaisilta, belgialaisilta, englantilaisilta ja yhdysvaltalaisilta valmistajilta. ${ }^{7}$

Gallen-Kallelan taiteellisessa tuotannossa on runsaasti aineistoa erilaisille materiaalitutkimuskokonaisuuksille. Tämän tutkimuksen tavoitteet rajautuivat paletin väriaineiden mahdollisimman kattavaan tunnistamiseen: Mitä väriaineita Gallen-Kallela on käyttänyt? Onko väriainepaletissa niin kutsuttuja karakteristisia väriaineita, joita hän on käyttänyt joko lähes jokaisessa työssään, ei koskaan tai aikakausisidonnaisesti? Tutkimuksellisen kiinnostuksen kohteena on myös teosten säilymisen kannalta oleellinen kysymys: Onko teoksissa väriaineita, joiden tiedetään haalistuvan tai tummuvan ikääntymisen myötä, väärissä olosuhteissa säilytettäessä tai näyttelyissä esille pantuina? Tunnistamisen menetelminä on käytetty mikroskopiaa, erityisesti kiteiden optisten ominaisuuksien tarkasteluun sopivaa polarisaatiomikroskopiaa, ja alkuaineanalyysiä (energiadispersiivinen röntgenfluoresenssi). Nämä menetelmät valkoituivat analyysimenetelmiksi niiden kustannustehokkuuden ja tuloksellisuuden vuoksi. Nämä seikat ovat merkittäviä, kun 
analysoidaan tämän tutkimuksen aineistomäärän kaltaisia kokonaisuuksia. Tämän tutkimuksen ulkopuolelle on rajattu arkistotutkimus, jossa perehdytään Gallen-Kallelan mahdolliseen kirjeenvaihtoon koskien hänen käyttämiään väriaineita. Tämän tutkimuksen tarkoituksena oli selvittää todelliset väriaineet, ei kerätä tietoa taiteilijan suosimista väriainevalmistajista.

Taiteilijakohtaisen väriainepaletin tunnistus ja taiteilijoiden välisen väriaineiden käytön eroavaisuuksien tutkimus ovat Suomessa uutta taiteen materiaalitutkimusta. ${ }^{8}$ Se tuottaa kiinteästi teokseen sidottua tietoa sen fyysisestä olemuksesta, materiaaleista ja niiden ikääntymisominaisuuksista. Tutkimus ei pelkästään tue taidehistorian sisällöntuotantoa $^{9}$ vaan auttaa tutkijoita arvioimaan teoksen mahdollisen elinkaaren pituutta, ikääntymisen hidastamismahdollisuuksia ja materiaaleille sopivia konservointitoimenpiteitä. Yksilöllisen väriainepaletin tunteminen auttaa tutkijoita myös teosten attribuoinnissa, eli nimeämisessä tietylle taiteilijalle, sekä mahdollisten väärennösten tunnistamisessa. Tuntemalla kunkin taiteilijan tyypillisesti käyttämät väriaineet tai vaihtoehtoisesti väriaineet, joita tämä ei koskaan käyttänyt, saadaan ensisijaisen tärkeää tietoa muiden tutkimustulosten lisäksi.

Maalaustaiteen teknisestä- ja materiaalianalyyttisesta tutkimuksesta on tullut oleellinen osa museoiden tekemää tutkimustyötä. ${ }^{10}$ Suomessa tutkimusta tehdään Kansallisgalleriassa (Valtion Taidemuseo vuosina 19902013), joka julkaisee tuloksiaan sekä FNG Research -verkkojulkaisusarjassaan että näyttelyjulkaisuissaan. Suomessa materiaalitutkimukset aloitettiin 1980-luvulla silloisen Suomen Taideakatemian konservaattoreiden toimesta, jolloin muutamien merkittävien teosten materiaali- ja maalaustekniikkatutkimuksia tehtiin yhteistyössä Helsingin yliopiston fysiikan laitoksen tutkijoiden kanssa. Oma materiaalitutkimuslaboratorio perustettiin vuonna 1999, jolloin Suomen Taideakatemia oli jo vaihtunut Valtion Taidemuseoksi.

Kansainvälisesti taiteilijakohtaiset väriainepalettitutkimukset ovat melko yleisiä ja niiden anti taiteentutkimukselle liittyy juuri teosten säilymisen turvaamiseen ja attribuointiin sekä taiteen aitoustutkimuksiin. Useimmiten taiteilijakohtaiset väriainepalettitutkimukset kohdistuvat yksittäisiin teoksiin tai tarkasti rajattuun aikakauteen, kuten on Vincent van Goghin ja Edvard Munchin koh- dalla. ${ }^{11}$ Kokonaispaletti on tunnistettu muun muassa Lucas Cranach vanhemmalta, ${ }^{12}$ Jan Vermeeriltä ${ }^{13}$ ja Ivan Aivazovskilta ${ }^{14}$. Tässä artikkelissa esitettävässä tutkimusaineistolaajuudessa ja samalla analyysimenetelmäyhdistelmällä tehtyjä taiteilijakohtaisia väriainepalettitutkimuksia on tehty vähän. Erityisesti polarisaatiomikroskopian käyttö väriainetutkimuksissa on vähäistä, vaikka se on käyttökustannuksiltaan kohtuuhintainen menetelmä, jolla pienestä näytemäärästä kyetään luotettavasti tunnistamaan suurin osa historiallisista epäorgaanisista väriaineista. Se on myös analyysimenetelmä, jonka käyttö tutkimuksessa olisi mahdollista myös pienemmille museo-organisaatioille. Tämän artikkelin yhtenä tavoitteena onkin korostaa joidenkin pitkään käytössä olleiden mutta nykyisin vähän käytettyjen analyysimenetelmien käytettävyyttä taiteen materiaalitutkimuksessa.

\section{Tutkittava aineisto ja tutkimusmene- telmät}

Tutkittavat teokset käsittävät Gallen-Kallelan Museon, Kansallisgallerian ja Serlachius-museoiden kokoelmien teoksia. Mukana on myös Gallen-Kallelan Museoon deponoituja 
yksityisten tahojen omistamia teoksia sekä yksittäisiä muiden tahojen omistamia teoksia. Tutkimuksen otanta sisältää sekä taiteilijan tunnetuimpaan tuotantoon kuuluvia- että tuntemattomampia teoksia. Myös harjoitelmia ja luonnoksia on otettu mukaan kokonaisuuteen. Kaiken kaikkiaan on tutkittu 265 teosta (taulukko 1). Aineistoon kuuluu kankaalle, paperille ja puulle maalattuja teoksia, joiden pääasiallinen sideaine on öljy. Aineistossa on myös kolme guassi- ja kahdeksan temperasideaineella toteutettua teosta. Näiden tueksi on tutkittu myös Gallen-Kallelan Museon kokoelmiin kuuluvat, oletettavasti itsensä Akseli Gallen-Kallelan käytössä olleet öljy- ja temperavärituubit, joista tutkittiin 83 kpl (taulukko 2). ${ }^{15}$

Gallen-Kallelan uran aikana oli saatavilla valmiiksi tinatuubeihin säilöttyjä sideaineeseen sekoitettuja yksittäisiä väriainejauheita ${ }^{16}$ ja valmiita väriaineseoksia. ${ }^{17}$ Tämän tutkimuksen aineistoon kuuluu erilaisia vihreitä väriaineseoksia sisältäviä väriainetuubeja. $\mathrm{Ne}$ on merkitty muun muassa kauppanimillä Behrendt green ${ }^{18}$, green cinnabar tai chrome green $^{19}$ ja permanent green ${ }^{20}$. Väriainetuubit sisälsivät useimmiten erilaisia synteettisiä väriaineita kuten synteettinen ultramariini, preussinsininen, erisävyiset rautaoksidipitoiset värit, koboltti-, kupari- ja kromiyhdisteet sekä orgaaniset väriaineet kuten eosiini (geranium lake) tai synteettinen alitsariini ${ }^{21}$. Vaikka taiteilijat olivat hyvin tarkkoja materiaaliensa aitoudesta ja kestävyydestä22, GalIen-Kallelan väriainetuubeja analysoitaessa huomattiin, että ne saattoivat sisältää muitakin väriaineita kuin mitä etiketissä ilmoitetaan.

Merkittävimmät tekijät, jotka vaikuttivat tutkimusmenetelmien valintaan, olivat ainetta rikkomattomuus ${ }^{23}$, tuloksellisuus ja kustannustehokkuus. Näiden perusteella tutkimusmenetelmiksi valikoituivat energiadispersiivinen röntgenfluoresenssispektroskopia (EDXRF) ja valomikroskopia, etenkin polarisaatiomikroskopia (PLM). EDXRF on täysin ainetta rikkomaton ja koskematon analyysimenetelmä kun taas PLM-tutkimusta varten tarvitaan pieni määrä näytettä. Näytemäärä on kuitenkin huomattavasti pienempi kuin mitä normaaliin museotyöhön liittyvässä taideteosten pintapuhdistuksessa tai lakan poistossa irtoaa teosten väripinnoilta. Menetelmien avulla saadun tiedon tueksi osa teoksista kuvannettiin UV- ja IR-säteilyä hyväksikäyttäen. Nämä kuvantamistek- niikat toimivat perustyökaluina tutkittaessa teoksen maalaustekniikkaa, mutta ne voivat myös toimia materiaalianalytiikan apuna. Niiden avulla ei tunnisteta käytettyjä materiaaleja ja väriaineita, mutta voidaan luoda hypoteeseja, jotka osaltaan edistävät tutkimusta.

Energiadispersiivisessä röntgenfluoresenssispektroskopiassa tutkittavaa kohdetta säteilytetään röntgensäteilyllä, jolloin kohteen sisältämien alkuaineiden atomit ryhtyvät emittoimaan niille ominaista röntgensäteilyä. Tämä säteily voidaan kerätä ja muuntaa röntgenfluoresenssispektriksi. Röntgenfluoresenssispektrissä eri alkuaineilla on piikkejä niille tunnusomaisilla paikoilla ja tämän perusteella voidaan alkuaineet tunnistaa. Tunnistettuja alkuaineita voidaan käyttää kohteen sisältämien yhdisteiden (maalausten kohdalla tutkittavien värialueiden sisältämien väriaineiden) tunnistuksessa. Usein röntgenspektreissä havaittavat alkuaineet viittaavat useaan erityyppiseen väriaineeseen tai osa väriaineista jää tunnistamatta, koska niiden koostumuksessa ei ole röntgenfluoresenssispektroskopian avulla havaittavia alkuaineita. ${ }^{24}$ Tällöin tutkimuksia voidaan täydentää optisen mikroskopian menetelmien avulla, joita ovat läpi- ja pinta- 
valomikroskopia, polarisaatiomikroskopia, UV- ja IR-mikroskopia. ${ }^{25}$

Polarisaatiomikroskopiassa näytettä tarkastellaan 100-400 kertaisella suurennoksella taso- ja ristiin polarisoidussa läpi- ja/ tai pintavaloissa. Tällöin havainnoidaan eri väriainepartikkeleille tyypillisiä optisia ominaisuuksia, joita ovat väriainepartikkelin koko, muoto, värisävy, erottuvuus väliaineesta (martio), taitekertoimen suuruus verrattuna väliaineeseen, kahtaistaitteisuus ja pleokroismi ${ }^{26}$. UV- ja IR-säteilylähteitä käytettäessä mikroskooppitarkastelussa tehdään havaintoja säteilyn vaikutuksesta ja käyttäytymisestä yksittäisissä väriainepartikkeleissa. Partikkeleita tarkastellaan myös Chelsea-suotimen avulla läpikulkevassa valossa, jolloin tietyt väriaineet muuttavat väriään. Tätä värimuutosta käytetään tunnistuksen apuna.

\section{Havainnot ja tulokset}

Gallen-Kallelan peruspaletin väriaineiksi osoittautuivat koboltinsininen, erilaiset rautapitoiset väriaineet, sinooperi, kadmiumkeltainen ja -oranssi sekä kromioksidi-/hydratoitu vihreä ja kromikeltainen. Sinisistä väriaineista suurella todennäköisyydellä myös syn- teettinen ultramariini kuuluu peruspalettiin. Preussinsininen oli taiteilijan suosiossa enemmän uran alkupuolella, kun taas synteettinen ultramariini esiintyy teoksissa ajallisesti melko tasaisesti. Sitä todettiin olevan myös useissa väriainetuubeissa. Kaikissa teoksissa ja useassa väriainetuubissa esiintyy myös erilaisia rautapitoisia värejä, joiden yksilöivä tunnistaminen rajattiin tutkimuksen ulkopuolelle. Gallen-Kallelan sivupalettiin kuuluvat smaragdinvihreä, seruleeninsininen, orgaaniset väriaineet, koboltinvihreä ja -violetti sekä kuparipitoinen vihreä ja/tai sininen väriaine (kaavio 1). Väriaineita, joita teoksista on tässä tutkimuksessa tunnistettu määrällisesti vain vähän, ovat koboltin- ja napolinkeltainen.

Valkoisista lyijyvalkoinen esiintyy jokaisessa teoksessa ja sinkkivalkoinen 253:ssa 265:stä tutkitusta teoksesta. Mustista väriaineista Gallen-Kallelalla on ollut käytössään ainakin rautaoksidi- ja luumusta. Musta voi olla myös seos rautaoksidipitoisista väriaineista ja koboltinsinisestä tai ultramariinista. Toisinaan seoksessa on sinooperia ja/tai hydratoitua kromioksidivihreää. Mustien ja tummien sävyjen käyttäminen on hyvin tyypillistä taiteilijan tuotannon realismin ja sym- bolismin aikaan. Tämä tulee erityisen hyvin esiin teoksissa Lieden ääressä $(1887)^{27}$, Ensi-opetus $(1887)^{28}$, Saunassa $(1889)^{29}$, saksalaisen näyttelijä Rudolf Rittnerin muotokuva (1895) j0 ja Lemminkäisen äiti (1897) ${ }^{31}$. Afrikan ajanjaksolla vuosina 1909-10 taiteilijan preussinsinisen käyttö oli vähäisempää ja vastaavasti heleiden värien, kuten koboltinvioletin ja seruleeninsinisen käyttö lisääntyi. (Linkit teoskuviin: https://www.kansallisgalleria.fi/fi/object/398461, https://www.kansallisgalleria.fi/fi/object/431404, https://www.kansallisgalleria.fi/fi/object/397073, https://www. kansallisgalleria.fi/fi/object/400728, https:// www.kansallisgalleria.fi/fi/object/398211).

Täyte- ja pohjusteaineina on käytetty bariumsulfaattia, kalsiumkarbonaattia sekä sinkki- ja lyijyvalkoista. Gallen-Kallelalla oli käytössään myös lyijypunainen, mutta väriainetuubien joukossa ei ole yhtään näin nimettyä tuubia, vaan kaikki lyijypunaista sisältävät väriainetuubit on nimetty sinooperiksi. Ei ole varmaa, oliko hän tietoinen siitä, että hän käytti sinooperin sijasta lyijypunaista.

Seuraavissa kappaleissa esitellään väriainekohtaisesti ne havainnot tutkimusaineistosta, joiden perusteella kyseessä olevat väriaineet voidaan tunnistaa.

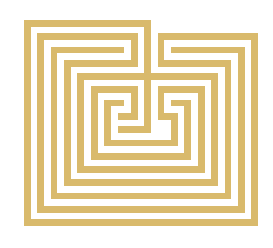




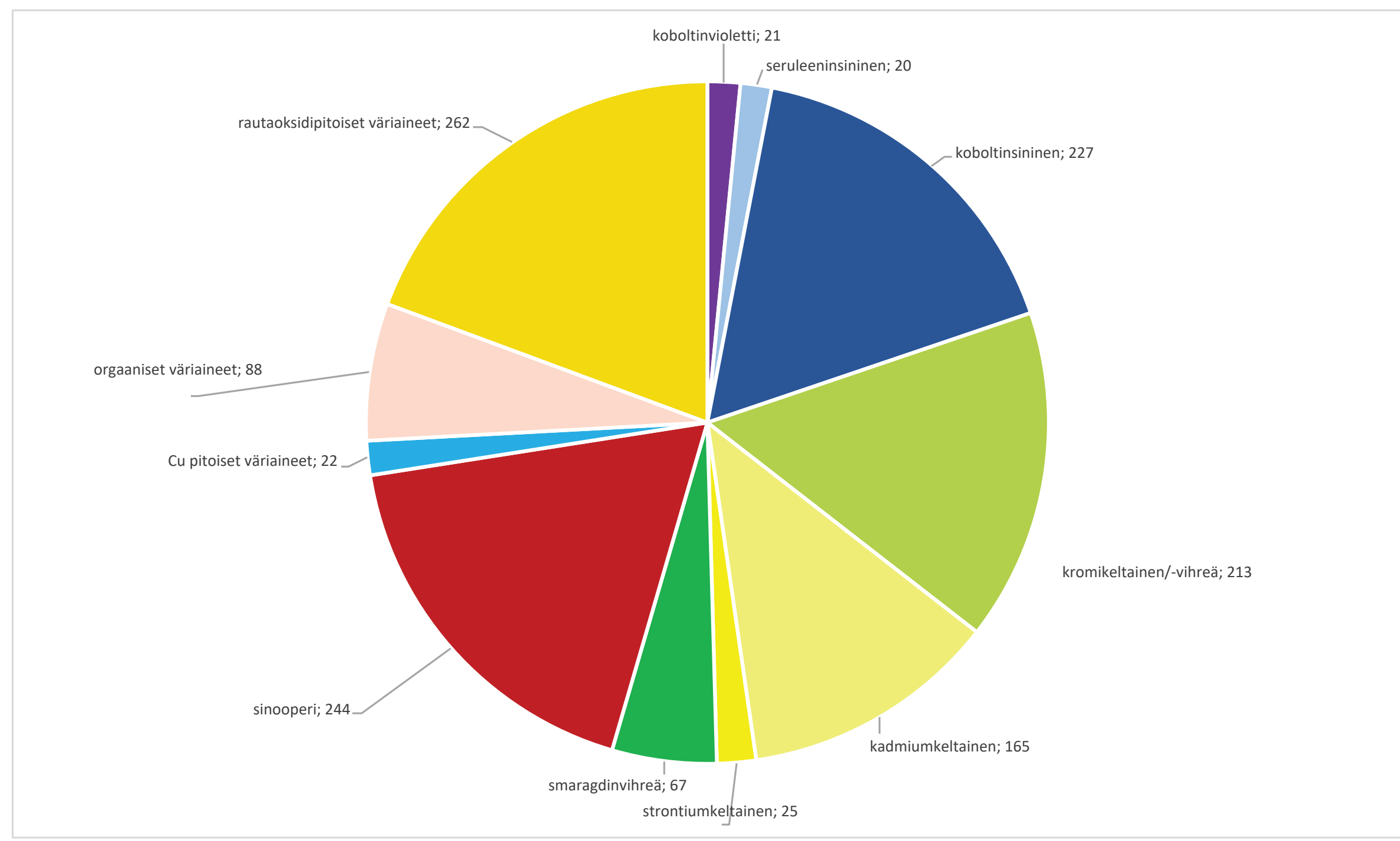

Kaavio 1.

Gallen-Kallelan perus- ja sivupalettien väriaineet. ${ }^{32}$ 


\section{Koboltinsininen}

Väriainetuubeissa neljässä ja 227:ssa 265:stä tutkitusta teoksesta on koboltinsinistä (kaavio 2). ${ }^{33}$ Koboltinsininen on kidejärjestelmältään kuutiollinen ja kemialliselta koostumukseltaan kobolttialumiinioksidia $\left(\mathrm{CoAl} \mathrm{O}_{4}\right) \cdot{ }^{34}$ Sen tunnistaminen tapahtuu röntgenfluoresenssispektrin avulla, josta tunnistetaan alkuaine koboltti. Usein tutkituissa teoksissa ja väriainetuubeissa koboltin kanssa esiintyy pieni määrä nikkeliä, joka on raaka-aineesta peräisin oleva epäpuhtaus. $^{35}$ Tasopolarisoidussa läpivalossa tarkasteltuna partikkelit ovat läpikuultavan sinisiä (kuva 2). Partikkelien martio ${ }^{36}$ vaihtelee heikosta kohtalaiseen ja partikkelien kokojakauma on laaja. Chelsea-suotimen läpi havainnoitaessa partikkelien sävy muuttuu vaalean sinisestä vaalean punaiseksi. Ristiin polarisoidussa läpivalossa partikkelit ovat isotrooppisia. Koboltinsininen esiintyy sekä yksin sinisenä väriaineena, että yhdessä muiden sinisten kanssa, ja myös osana vihreää tai violettia seosta.

Edellä mainitut havainnot ovat tyypillisiä koboltinsinisen optisista ominaisuuksista tehtyjä havaintoja. Kirjallisuudessa mainituista havainnoista poikkeavaa sen sijaan on tutkimusaineistosta kerättyjen näytteiden taitekerroin, joka on pääsääntöisesti pienempi kuin väliaineen $(<1,662)$. Koboltinsinisen väriaineen taitekertoimen ilmoitetaan tavallisesti olevan suurempi kuin väliaineen $(1,66-1,78) .{ }^{37}$ Kuitenkin, lähes kaikissa Kansallisgalleriassa tutkituissa koti- ja ulkomaisissa teoksissa, jotka ajoittuvat 1800-1900-lukujen taitteeseen, koboltinsinisen taitekerroin on väliainetta pienempi. Tämä voi tarkoittaa sitä, että historiallisen koboltinsinisen taitekerroin on useimmiten pienempi kuin väliaineen ja modernin suurempi. Tieteellisiä artikkeleja tästä ei kuitenkaan vielä ole julkaistu.

\section{Seruleeninsininen}

Toinen kobolttipitoinen sininen, joka on tunnistettu sekä teoksista että värituubeista, on seruleeninsininen $^{38}$, joka on kidejärjestelmältään kuutiollinen ja kemialliselta koostumukseltaan kobolttitinaoksidia $\left(\mathrm{CoSnO}_{3}\right)$. Teos- ja materiaaliotannasta seruleeninsinistä esiintyy kahdessa öljyvärituubissa, mutta teoksissa sitä esiintyy kohtalaisen vähän: 20:ssa 265:stä tutkitusta teoksesta. Selvä piikki tämän väriaineen käytössä on Gallen-Kallelan värien heleytymisen aikaan 1910-luvulla, jonka jälkeen valmistuneis- ta ja tutkituista teoksista se on tunnistettu kuudestatoista. Ottaen huomioon, että seruleeninsininen on tunnistettu yhteensä 20:sta teoksesta, sijoittuu sen käyttö Gallen-Kallelan uralla 1910-luvun jälkeiselle ajanjaksolle (kaavio 3).

Tutkimusaineistosta seruleeninsininen tunnistetaan röntgenfluoresenssispektrin avulla, jossa koboltin lisäksi esiintyy tina. Tutkituissa teoksissa ja väriainetuubeissa mitatuista röntgenfluoresenssispektreistä havaitaan usein myös pieni määrä nikkeliä, joka on raaka-aineesta johtuva epäpuhtaus. Seruleeninsininen voidaan tunnistaa myös polarisaatiomikroskopian avulla. Tarkasteltaessa näytettä tasopolarisoidussa läpivalossa partikkelit näyttävät pyöristyneiltä. $\mathrm{Ne}$ ovat läpikuultavia ja väriltään vaalean sinisiä (kuva 2). Partikkelit ovat pieniä ja niiden kokojakauma on kapea. Partikkelin martio on kohtalainen ja taitekerroin suurempi kuin väliaineen $(>1,662)$. Chelsea-suotimen läpi tarkasteltuna tummemman siniset partikkelit ja aggregaatit (partikkelikasaumat) näyttävät haalean vaaleanpunaisilta, vaaleamman siniset partikkelit harmailta. Ristiin polarisoidussa läpivalossa partikkelit ovat isotrooppisia. Tämä väriaine esiintyy yleisimmin 


\section{KOBOLTINSININEN}

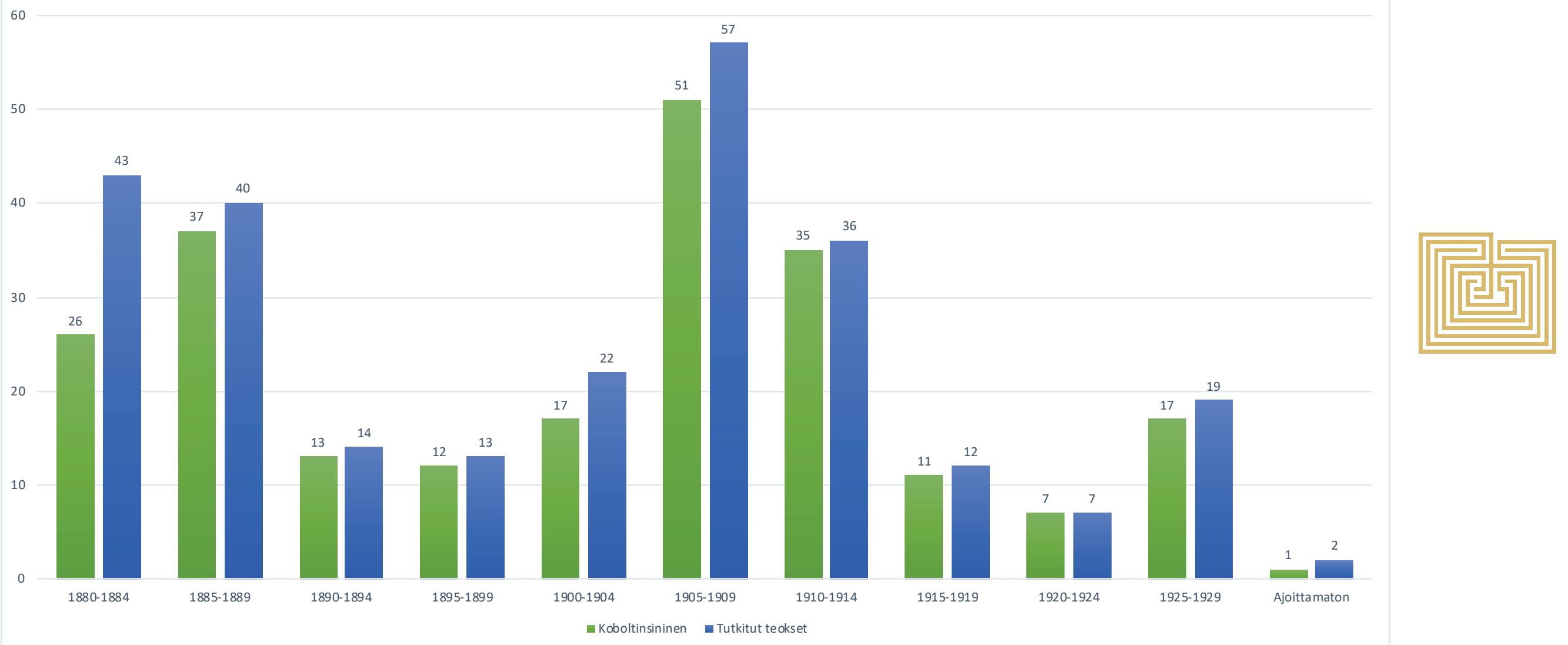

Kaavio 2.

Koboltinsinisen esiintyminen teoksissa aikakausittain 


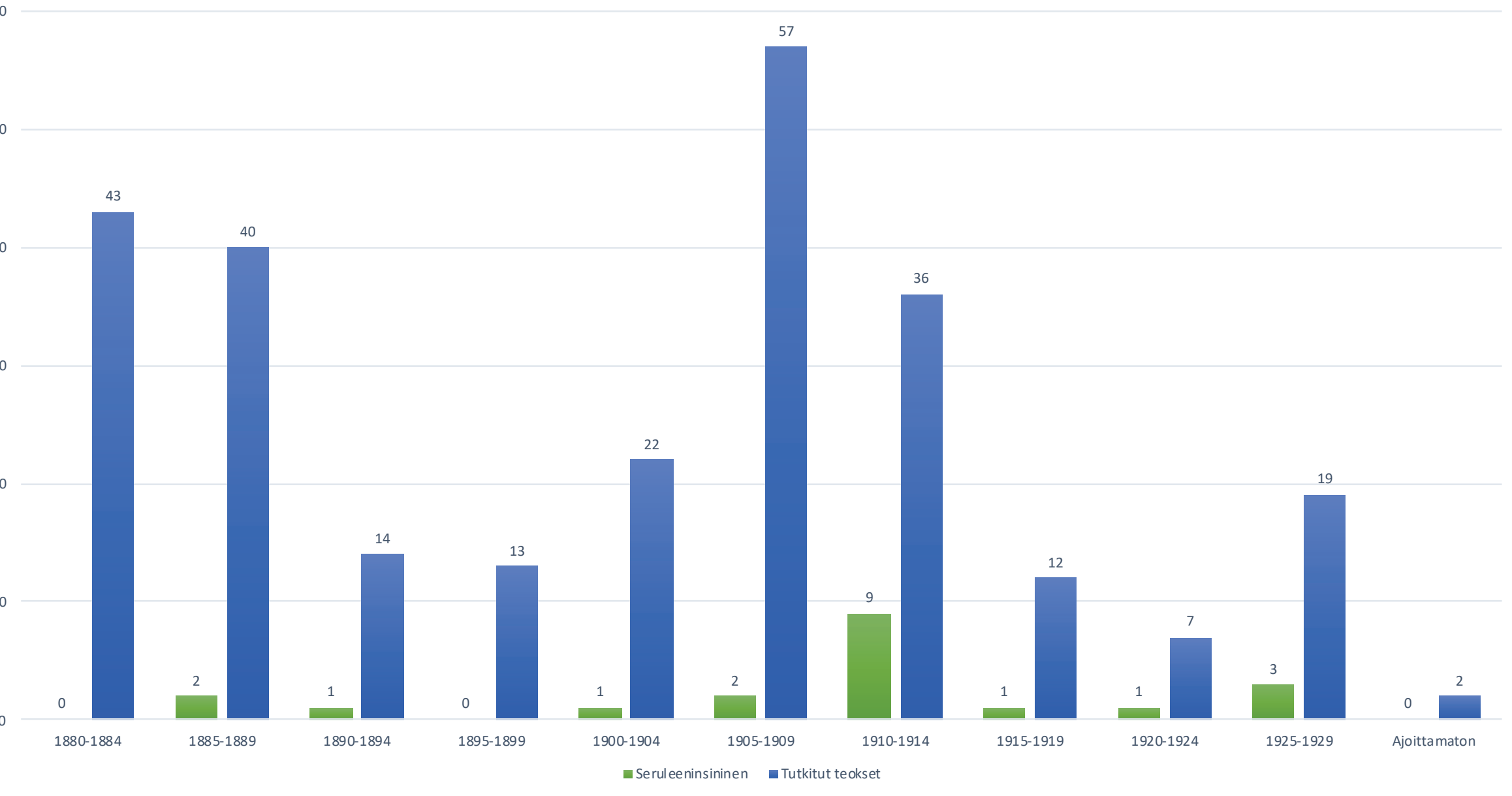

Kaavio 3.

Seruleeninsinisen esiintyminen teoksissa aikakausittain 

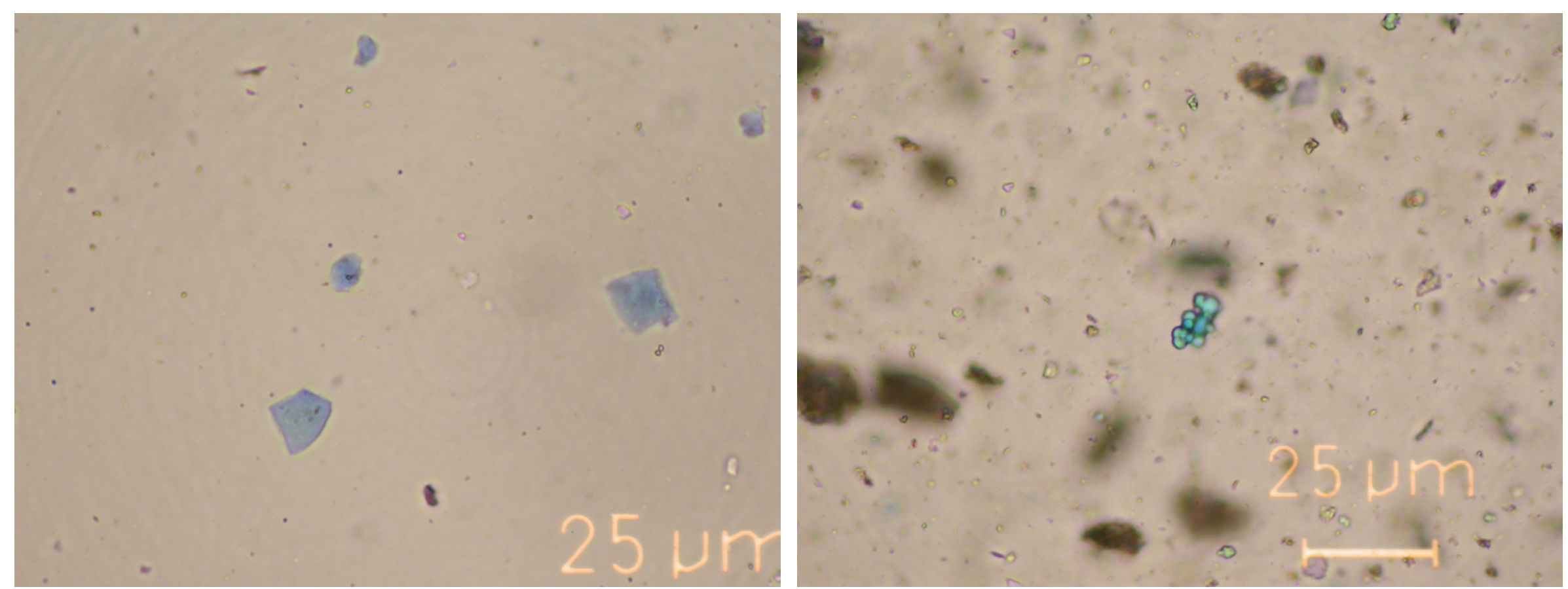

Kuva 2. Koboltinsinisen väriainepartikkeli tasopolarisoidussa läpi- Kuva 3. Seruleeninsinisen väriainepartikkeleja aggregaattina tavalossa. Näyte teoksesta, Iltamaisema eläintarhasta, 1886. Öljyväri sopolarisoidussa läpivalossa. Näyte teoksesta Kukkiva korallipuu, kankaalle, 24,5 x 31 cm. Ateneum, Helsinki. Kansallisgalleria, in- 1909-10. Öljyväri puulle, 29,5 x 26 cm. Ateneum, Helsinki. Kansalventaarionumero A III 1725. Kuva: Kansallisgallerian materiaalitut- lisgalleria, inventaarionumero A III 2178. Kuva: Kansallisgallerian kimuslaboratorio / Seppo Hornytzkyj. (Linkki teoskuvaan: https:// www.kansallisgalleria.fi/fi/object/419134). materiaalitutkimuslaboratorio / Seppo Hornytzkyj. (Linkki teoskuvaan: https://www.kansallisgalleria.fi/fi/object/429050). 
sinisillä värialueilla, ei niinkään vihreissä tai violeteissa seoksissa.

\section{Preussinsininen}

Tutkituista teoksista 12:sta tunnistettiin preussinsininen. ${ }^{39}$ Se näyttää esiintyvän Gallen-Kallelan tuotannossa pääasiallisesti ennen 1900-lukua; yhteensä 57:stä teoksesta otettiin polarisaatiomikroskopianäytteitä ja 12:sta se tunnistettiin. Kaikki teokset, joissa se esiintyy, ovat valmistuneet ennen 1900-lukua yhtä vuonna 1905 valmistunutta teosluonnosta ${ }^{40}$ lukuun ottamatta.

Preussinsininen ${ }^{41}$ on synteettinen epäorgaaninen yhdiste. Se on kidejärjestelmältään kuutiollinenjakemialliselta koostumukseltaan heksasyanoferraattia (II) $\left(\mathrm{Fe}_{4}{ }_{4}\left[\mathrm{Fe}^{2}(\mathrm{CN})_{6}\right]_{3}\right.$. $\left.\mathrm{xH}_{2} \mathrm{O}(\mathrm{x}=14-16)\right)$. Preussinsinisen tunnistaminen tapahtuu polarisaatiomikroskopian avulla. Röntgenfluoresenssispektrissä havaitaan rauta, joka kuuluu preussinsinisen koostumukseen, mutta koska rauta on väri- ja täyteaineissa yleinen alkuaine, ei sen läsnäoloa spektrissä voida käyttää preussinsinisen tunnistamiseen. Tunnistaminen tapahtuu polarisaatiomikroskopian avulla. Tunnistamisen apuna voi käyttää IR-reflektio- (IRR) tai -läpivalotarkastelua. Koska preussinsininen absorboi IR-säteilyä se näkyy IR-tarkastelussa mustana.

Preussinsinisen partikkelit ovat hyvin pieniä eikä yksittäisiä partikkeleita voi erottaa valomikroskopian avulla. Partikkelit muodostavat kuitenkin usein aggregaatteja, jotka saattavat olla kooltaan kohtalaisen suuria tai vaihtoehtoisesti ne ovat kiinnittyneet suurempipartikkeliseen kantajaan. Tasopolarisoidussa läpivalossa aggregaatit näkyvät toisinaan opaakkeina ja toisinaan kohtalaisen läpikuultavina, joskus kirkkaan ja toisinaan hyvin tumman tai vihertävän sinisinä partikkelikasaumina (kuva 3). ${ }^{42}$ Näiden väri ei muutu Chelsea-suotimella tarkasteltaessa. ${ }^{43}$ Preussinsinisen martio on kohtalainen ja taitekerroin on pienempi kuin väliaineen $(<1,662)$. Pienestä partikkelikoosta johtuen martion ja taitekertoimen havaitseminen on vaikeaa. Ristiin polarisoidussa läpivalossa preussinsininen on isotrooppinen. Preussinsinistä esiintyy muissa teoksissa sekä vihreillä että sinisillä värialueilla. Väriainetuubissa se esiintyy osana vihreää seosta. ${ }^{44}$ Väriaine voi valmistustavasta riippuen haalistua tai muuttaa väriään valolle altistuessaan. Erityisesti jos se on teoksessa seoksena valkoisten väriaineiden kanssa. ${ }^{45}$
Preussinsinistä Gallen-Kallela on käyttänyt sekä sinisenä että yhdessä kromikeltaisen kanssa, jolloin tuloksena on vihreä värisävy, jota on kutsuttu nimellä kromivihreä. Näin on esimerkiksi teoksissa Poika ja varis $^{46}$ vuodelta 1884 ja Tohtori Herman Frithiof Antellin muotokuva ${ }^{47}$ vuodelta 1886. (Linkit teoskuviin: https://www.kansallisgalleria.fi/fi/ object/406902, https://www.kansallisgalleria. fi/fi/object/391665).

\section{Synteettinen ultramariini}

Ultramariini, jota Gallen-Kallela käytti, on poikkeuksetta synteettistä ultramariinia. ${ }^{48}$ Tutkituista teoksista 23:ssa 265:stä teoksesta ${ }^{49}$ ja väriainetuubeista kahdeksassa esiintyy synteettistä ultramariinia. Tunnistaminen tapahtuu polarisaatiomikroskopian avulla, joka on myös ainoa analyysimenetelmä, jolla voi erottaa toisistaan aidon ja synteettisen ultramariinin. Synteettisen kohdalla on myös mahdollista selvittää, onko kyseessä varhainen vai myöhäisempi versio. ${ }^{50}$

Kemialliselta koostumukseltaan ultramariini on natriumalumiinisilikaattia $\left(\mathrm{Na}_{6-10} \mathrm{Al}-\right.$ $\left.{ }_{6} \mathrm{Si}_{6} \mathrm{O}_{24} \mathrm{~S}_{2-4}\right)$. Sen kiderakenne on kuutiollinen ja koostumus voi vaihdella lähtöaineista ja niiden seossuhteista riippuen. ${ }^{51}$ Läpikulke- 
vassa tasopolarisoidussa valossa partikkelit ovat läpikuultavia, toisinaan opaakkeja, tasaisesti värjäytyneitä ja sinisiä. Synteettisellä ultramariinilla on tasaisempi väri kuin luonnon ultramariinilla, mutta varhaisissa synteettisissä ultramariinipartikkeleissa väri voi olla epätasaisesti jakautunut. Partikkelit ovat kohtalaisen pyöreitä, pieniä ja niiden kokojakauma on kapea (kuva 4). Chelsea-suotimella tarkasteltuna niiden väri muuttuu kirkkaan punaiseksi. Synteettisellä ultramariinilla väri muuttuu hieman intensiivisemmäksi punaiseksi kuin luonnon ultramariinilla. Sekä luonnon että synteettisen ultramariinin martio on selvä ja taitekerroin alhaisempi kuin väliaineella $(<1,662)$. Ristiin polarisoidussa läpivalossa partikkelit ovat isotrooppisia. Synteettistä ultramariinia esiintyy sinisillä, vihreillä ja violeteilla värialueilla.

\section{Sinooperi}

Sinooperi52 kuuluu Gallen-Kallelan peruspalettiin ja sitä on tunnistettu 244:ssä 265:stä teoksesta (kaavio 4). Väriainetuubeissa sinooperia esiintyy vain tuubissa, jonka nimi on Karmin-Zinnober. ${ }^{53}$

Sinooperi on kemialliselta koostumukseltaan elohopeasulfidia ( $\mathrm{HgS})$ ja kidera- kenteeltaan heksagonaalinen. Sinooperin tunnistaminen on yksinkertaista pelkästään röntgenfluoresenssispektrin avulla; se on ainoa yleisesti käytössä oleva punainen väriaine, joka sisältää elohopeaa (spektri 1). Sinooperia on olemassa sekä luonnonmineraalina että synteettisesti tuotettuna mineraalina. Synteettisen valmistamiseen on olemassa kaksi eri menetelmää. Näistä toinen, kuivaprosessi, tuottaa samanlaisia väriainepartikkeleita murskattuna ja jauhettuna kuin luonnon sinooperi. Märkäprosessi tuottaa pieniä tasakokoisia kiteitä, joita ei erikseen jauheta väriaineeksi. ${ }^{54}$ Sinooperin kohdalla näytteenotto on perusteltua silloin, kun halutaan selvittää kummalla prosessilla tuotettu synteettinen sinooperi on kyseessä. Tasopolarisoidussa läpivalossa partikkelit ovat syvän punaisia, toisinaan jopa opaakkeja. Sinooperi-partikkelien martio on selvä ja taitekerroin on korkeampi kuin väliaineen $(>1,662)$. Partikkelikokojakauma on märkäprosessilla tuotetussa kapea ${ }^{55}$ ja kuivaprosessilla tuotetussa laaja ${ }^{56}$. Ristiin polarisoidussa läpivalossa partikkelit ovat anisotrooppisia ja partikkelin oma punainen väri on havaittavissa.

\section{Kadmiumkeltainen ja -oranssi}

Gallen-Kallelan peruspalettiin kuuluu niin ikään kadmiumkeltainen ja/tai -oranssi ${ }^{57}$, jota on tunnistettu 165:ssä 265:stä teoksista, samoin kuin viidestä väriainetuubista (kaavio 5). Kadmiumkeltainen ja -oranssi ovat molemmat kemialliselta koostumukseltaan kadmiumsulfidia (CdS) ja niiden kiderakenne vaihtelee valmistustavasta ja yhdisteestä riippuen. ${ }^{58}$ Yhdisteitä on kehitetty useita, jotta saatiin käyttöön erilaisia sävyjä, jotka vaihtelevat vaalean sitruunankeltaisesta oranssiin. ${ }^{59}$ Kadmiumsulfidiväriaineita vastaavia luonnonmineraaleja ovat greenokiitti ja hawleyiitti, joista ainakin greenokiittia on käytetty taiteilijaväriaineena. ${ }^{60}$ Gallen-Kallelan teoksista ja väriainetuubeista kadmiumkeltainen ja/tai -oranssi on tunnistettu röntgenfluoresenssispektrissä esiintyvän kadmiumin avulla (spektri 2). Tutkituista kohteista yhden Weimarfarben valmistaman väriainetuubin ja yhden teoksen ${ }^{61}$ kadmiumkeltaisessa on epäpuhtautena pieni määrä talliumia.

Toisinaan erityisesti vihreitä ja oransseja väriseoksia tutkittaessa on otettu näyte polarisaatiomikroskoppitutkimusta varten. Tasopolarisoidussa läpivalossa kadmiu-

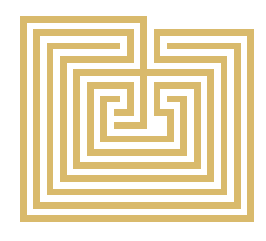




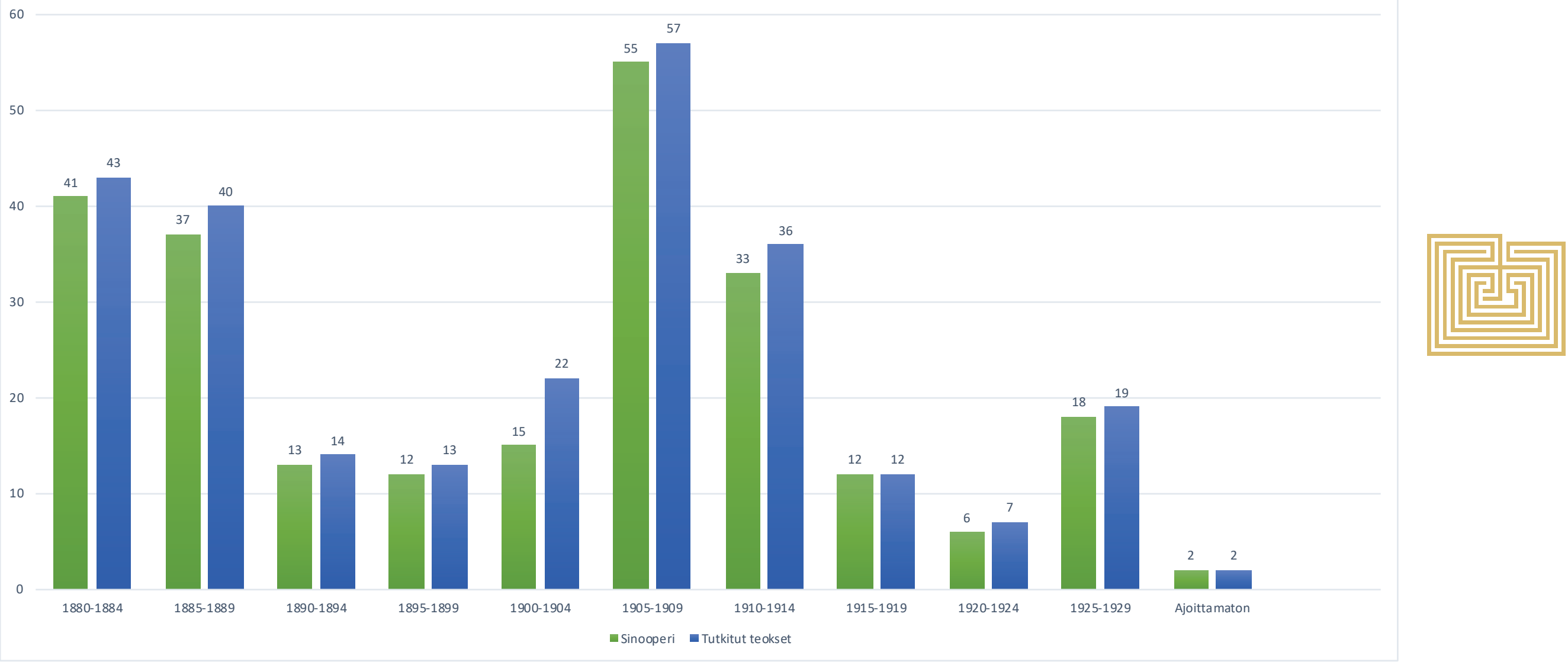

Kaavio 4.

Sinooperin esiintyminen teoksissa aikakausittain 


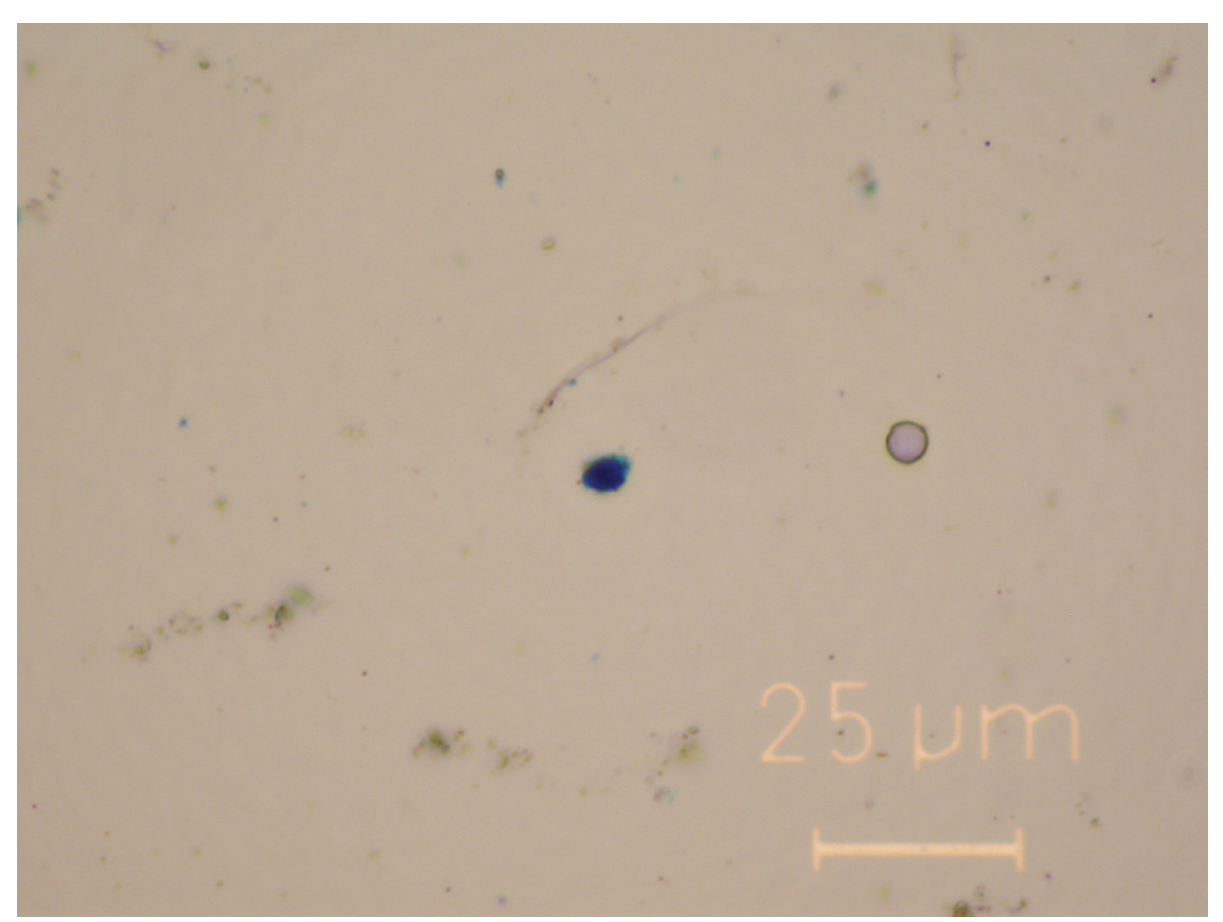

Kuva 4. Preussinsinisen partikkeliaggregaatti tasopolarisoidussa läpivalossa. Näyte teoksesta Kuusia karjapihassa, 1887. Öljyväri kankaalle, 28 × 25 cm. Ateneum, Helsinki. Kansallisgalleria, inventaarionumero A II 1248 Kuva: Kansallisgallerian materiaalitutkimuslaboratorio / Seppo Hornytzkyj. (Linkki teoskuvaan: https:// www.kansallisgalleria.fi/fi/object/616549).

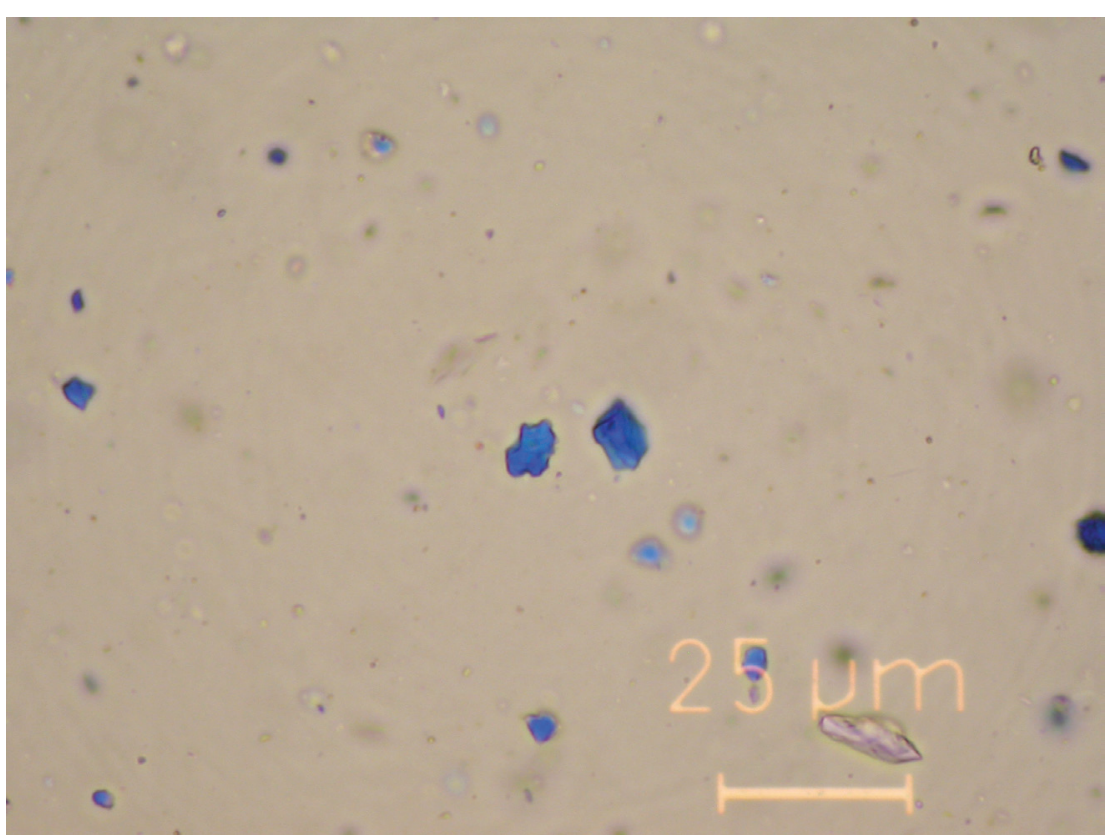

Kuva 5. Synteettisiä ultramariininsinisen väriainepartikkeleita tasopolarisoidussa läpivalossa. Näyte teoksesta Sammon ryöstö, osaluonnos, 1905. Öljyväri kankaalle, 73 x $51 \mathrm{~cm}$. Serlachius-museot, Mänttä. Serlachius-museot, inventaarionumero 98. Kuva: Kansallisgallerian materiaalitutkimuslaboratorio / Seppo Hornytzkyj.

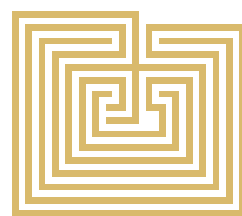




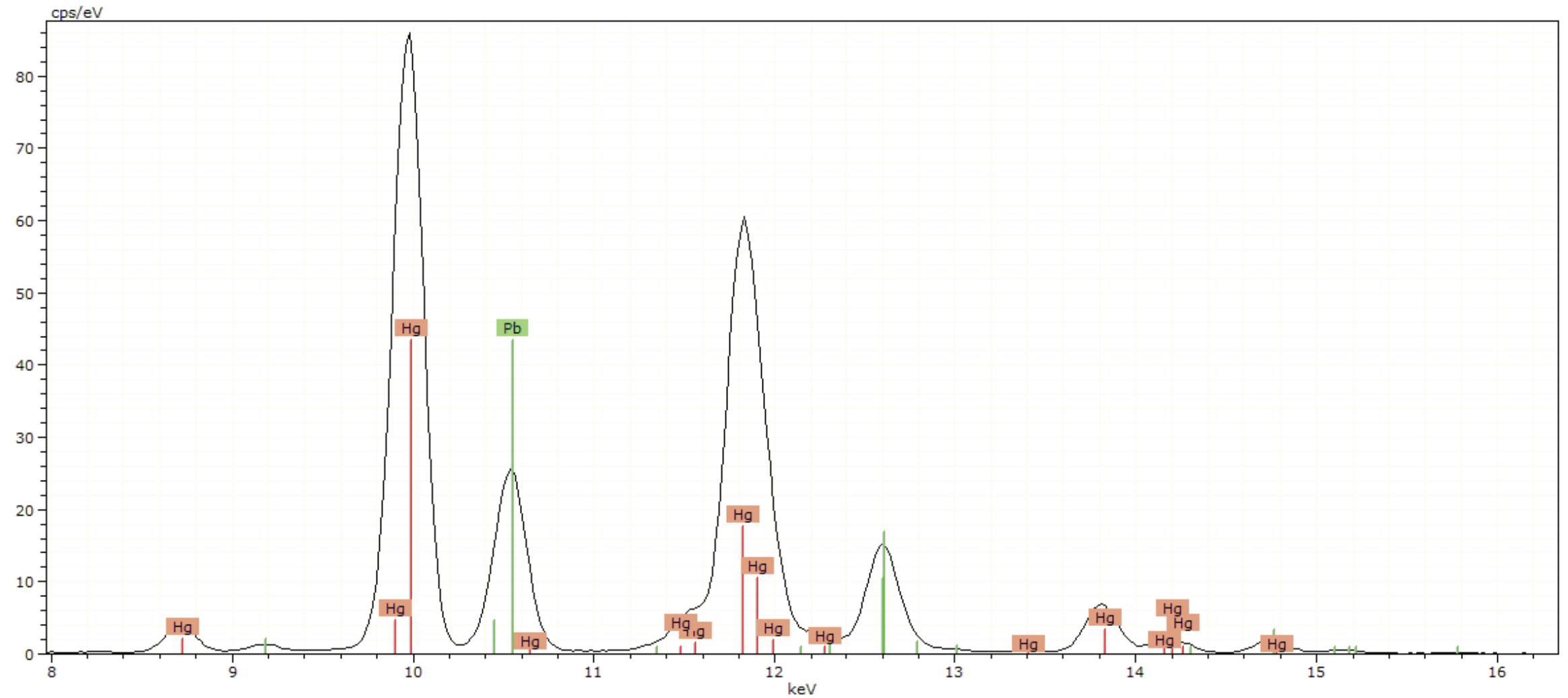

Spektri 1.

Röntgenfluoresenssispektri teoksesta, Kuu, 1909. Öljyväri kankaalle, 31,5 x 31,5 cm.

Gallen-Kallelan Museo, Espoo. Spektri: Kansallisgallerian materiaalitutkimuslaboratorio / Hanne Tikkala. 

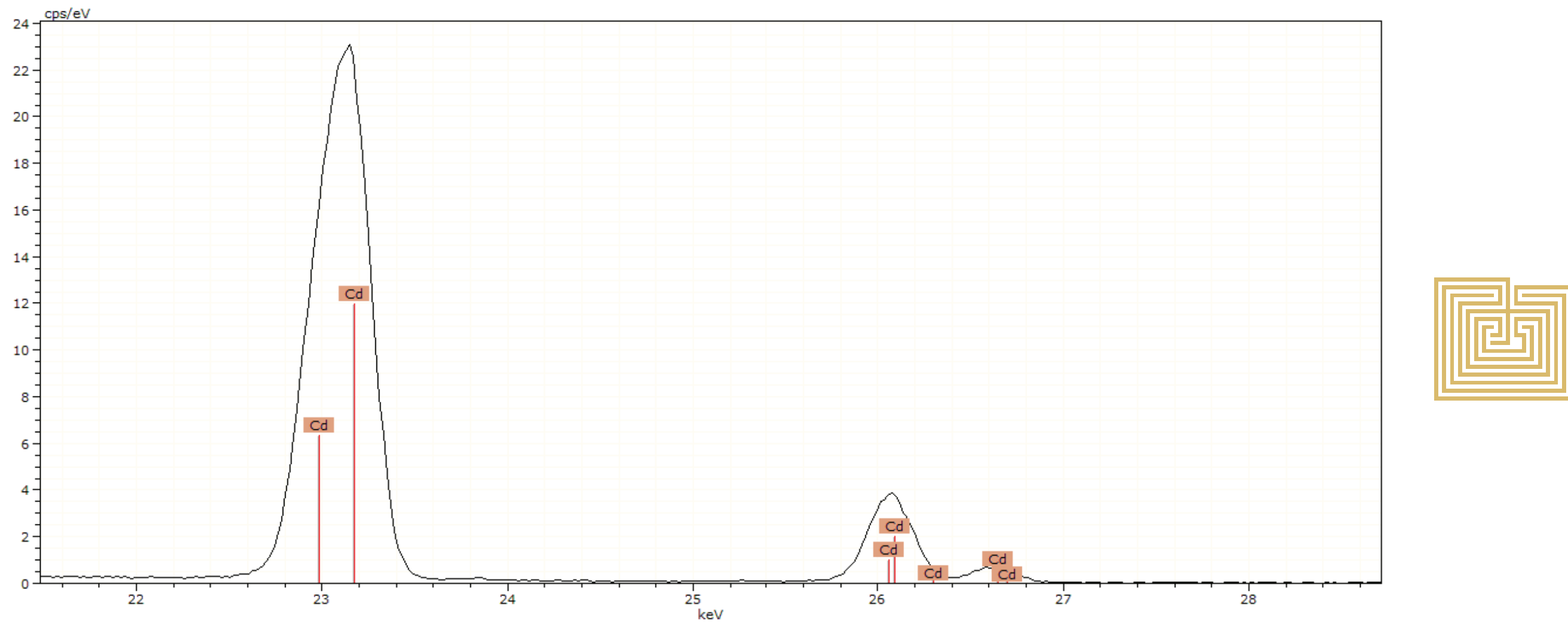

Spektri 2.

Röntgenfluoresenssispektri teoksesta Aallottaria, 1909. Öljyväri kankaalle, 53,5 x $73 \mathrm{~cm}$.

Ateneum, Helsinki. Kansallisgalleria, inventaarionumero A-1995-96. Spektri: Kansallisgallerian materiaalitutkimuslaboratorio / Hanne

Tikkala. (Linkki teoskuvaan: https://www.kansallisgalleria.fi/fi/object/501754). 


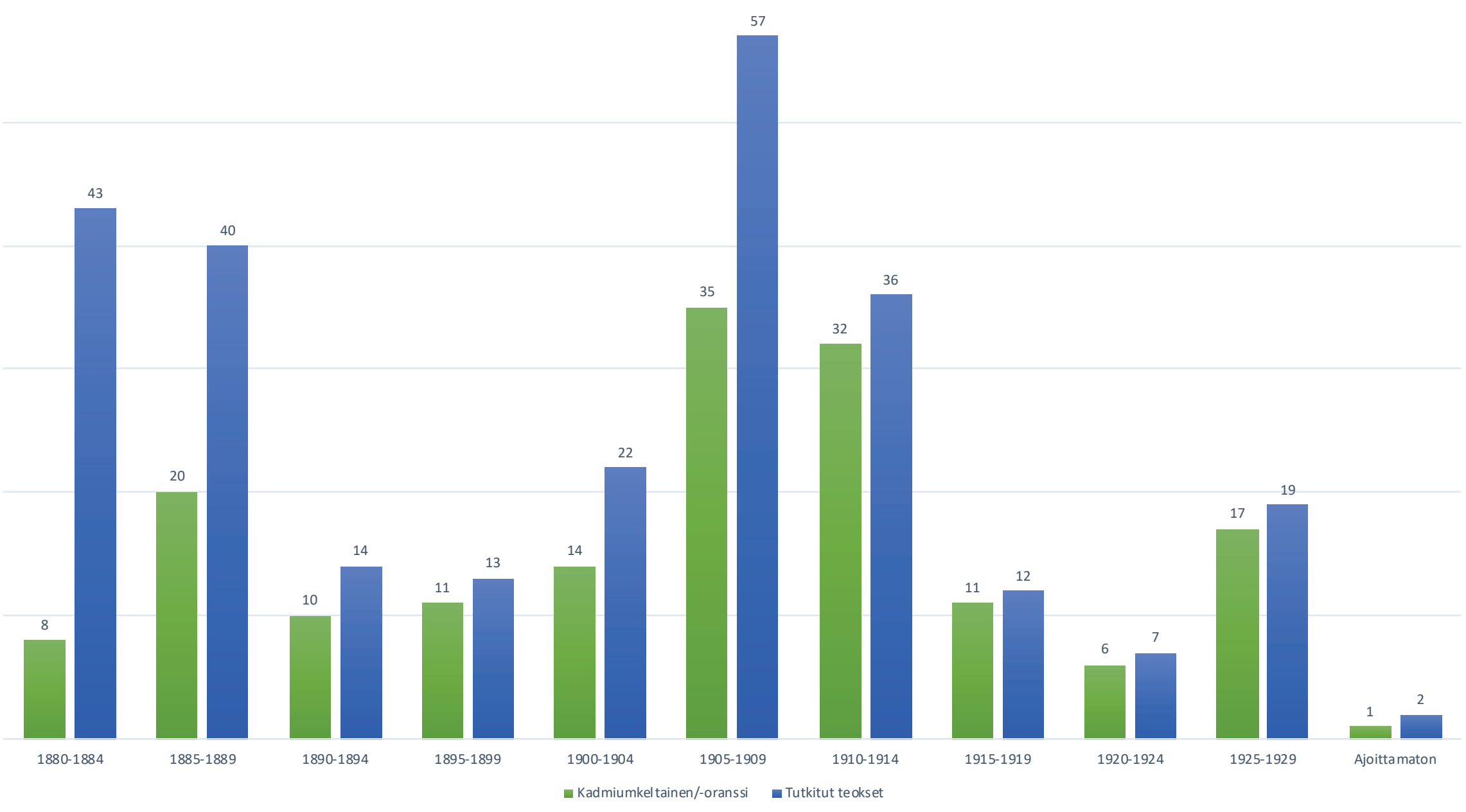

Kaavio 5.

Kadmiumkeltaisen ja/tai -oranssin esiintyminen teoksissa aikakausittain. 
mkeltaisen partikkelit ovat hyvin pieniä ja partikkelikokojakauma on kapea. Muoto on pyöristynyt, martio selvä ja taitekerroin suurempi kuin väliaineen $(>1,662)^{62}$. Ristiin polarisoidussa läpivalossa kadmiumkeltainen voi kiderakenteesta riippuen olla iso- tai anisotrooppista. ${ }^{63}$ Kadmiumkeltainen voi kiderakenteesta riippuen aiheuttaa öljysideaineen rapautumista. Se voi myös haalistua tai tummua. $^{64}$

\section{Kromipitoiset vihreät ja keltaiset}

Kromipitoiset väriaineet ovat hyvin tyypillisiä Gallen-Kallelan tuotannossa. Niitä on tunnistettu 213:ssa 265:stä tutkitusta teoksesta sekä 12:ssa 83:sta tutkitusta väriainetuubista (kaavio 6). Usein on kyse joko synteettisestä keltaisesta lyijykromaatista $\left(\mathrm{PbCrO}_{4}\right)^{65}$ tai synteettisestä vihreästä hydratoidusta kromioksidista $\left(\mathrm{Cr}_{2} \mathrm{O}_{3} \cdot 2 \mathrm{H}_{2} \mathrm{O}\right)^{66}$. Huomattavasti harvemmin hän on käyttänyt synteettistä strontiumkromaattia $\left(\mathrm{SrCrO}_{4}\right)^{67}$. Gallen-Kallelan teoksista on kromipitoisia väriaineita löytynyt sekä keltaiselta että vihreältä alueelta. Kun vihreältä alueelta tunnistetaan röntgenfluoresenssispektristä kromi, tulosta ei voida tulkita kromivihreäksi ilman, että se varmistetaan polarisaatiomikroskooppitutkimuksel- la. ${ }^{68}$ Jos kromin lisäksi esiintyy huomattava määrä strontiumia, mutta ei lainkaan kalsiumia tai bariumia, voidaan vihreällä alueella oleva keltainen väriaine tunnistaa strontiumkeltaiseksi (spektri 3).

Keltaiset lyijykromaattipartikkelit ovat kiderakenteeltaan monokliinisia, mutta se voi vaihdella valmistustavasta riippuen ${ }^{69}$. Keltaisen lyijykromaatin vastinemineraali luonnossa on krokoiitti, jota ei luultavimmin ole käytetty taiteilijaväriaineena. ${ }^{70}$ Tasopolarisoidussa läpivalossa partikkelit ovat läpikuultavia, oranssinkeltaisia prismoja. Partikkelikoko on hyvin pieni ja partikkelikokojakauma on kapea. Martio on selvä ja taitekerroin suurempi kuin väliaineen $(>1,662)$. Ristiin polarisoidussa läpivalossa partikkelit ovat anisotrooppisia ja niissä on havaittavissa partikkelin oma keltainen väri. Keltainen lyijykromaatti voi menettää väriään tai tummua valon vaikutuksesta. ${ }^{71}$

Strontiumkromaattia on tunnistettu Gallen-Kallelan teoksista vihreältä alueelta 25:stä tutkitusta 265:stä teoksesta (kaavio 7). Strontiumkromaattipartikkelit ovat kiderakenteeltaan monokliinisia. Tasopolarisoidussa läpivalossa ne havaitaan neulamaisina sekä haalean keltaisina ja läpikuultavina.
Partikkeleiden martio on kohtalainen ja taitekerroin suurempi kuin väliaineen $(<1,662)$. Ristiin polarisoidussa läpivalossa partikkelit ovat anisotrooppisia ja ne havaitaan keltaisina tai valkoisina. Erityisesti Gallen-Kallela on suosinut tätä väriainetta opiskeluaikoinaan 1880-luvulla kuten teoksessa Pariisilainen takapiha ${ }^{72}$ vuodelta 1884 (linkki teoskuvaan: https://www.kansallisgalleria.fi/ fi/object/469423) ja Afrikan matkansa aikoihin. Tämän ajan teoksista strontiumkeltainen on tunnistettu esimerkiksi teoksesta Jokilaakso ${ }^{73}$ vuodelta 1909. (Linkki teoskuvaan: https://www.kansallisgalleria.fi/fi/object/430812).

Synteettisellä hydratoidulla kromioksidivihreällä ei ole luonnossa vastinemineraalia. $^{74}$ Hydratoidun kromioksidivihreän kiderakenne vaihtelee heksagonaalisesta romboedriseen. ${ }^{75}$ Läpikulkevassa valossa partikkelit ovat läpikuultavia, kirkkaan vihreitä ja tasaisesti värjäytyneitä (kuva 5). Partikkelin martio on selvä ja taitekerroin suurempi kuin väliaineen $(>1,662)$. Partikkelikokojakauma on laaja. Ristiin polarisoidussa läpivalossa partikkelit ovat anisotrooppisia ja niiden oma sinivihreä väri on havaittavissa.

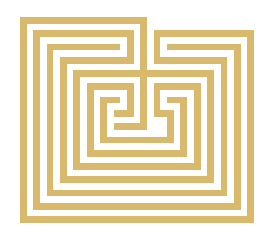


KROMIVIHREÄ / -KELTAINEN

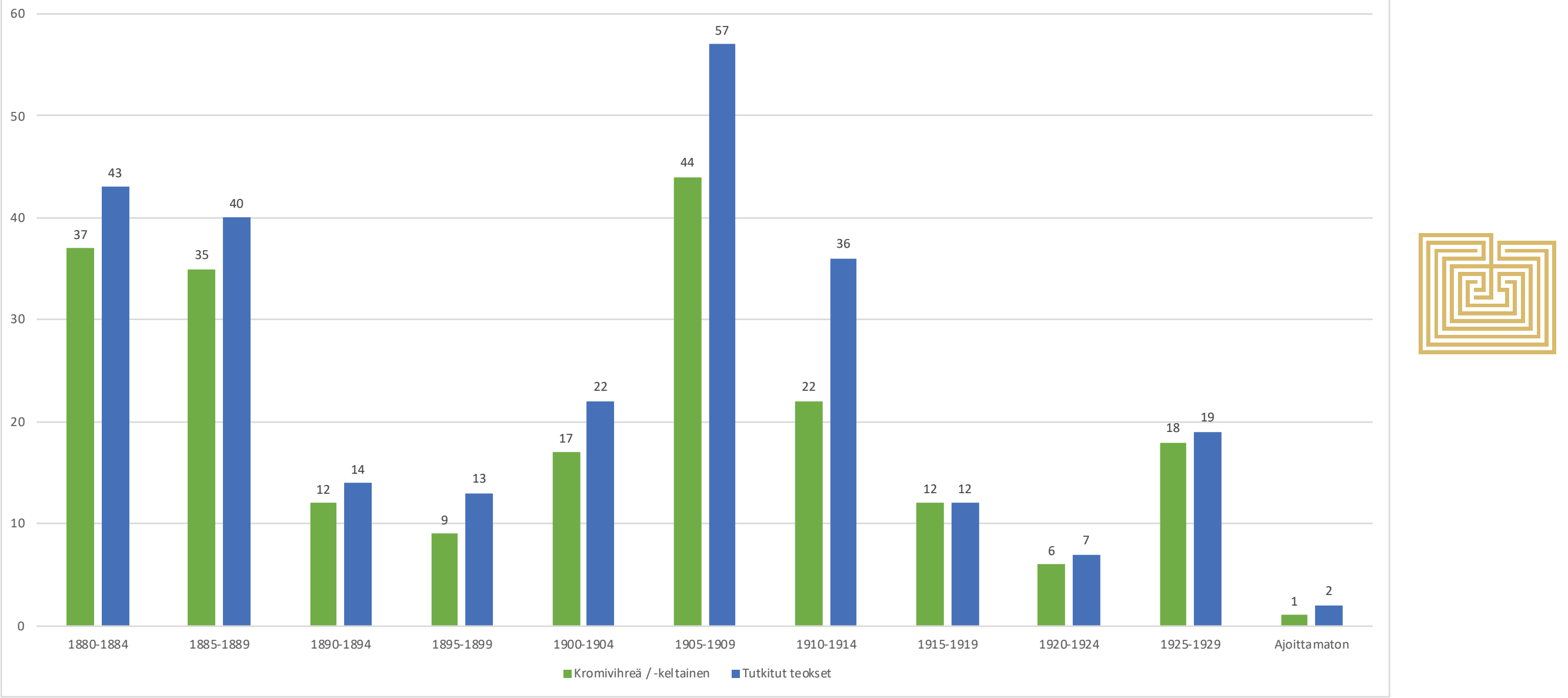

Kaavio 6.

Kromivihreän ja -keltaisen esiintyminen teoksissa aikakausittain 

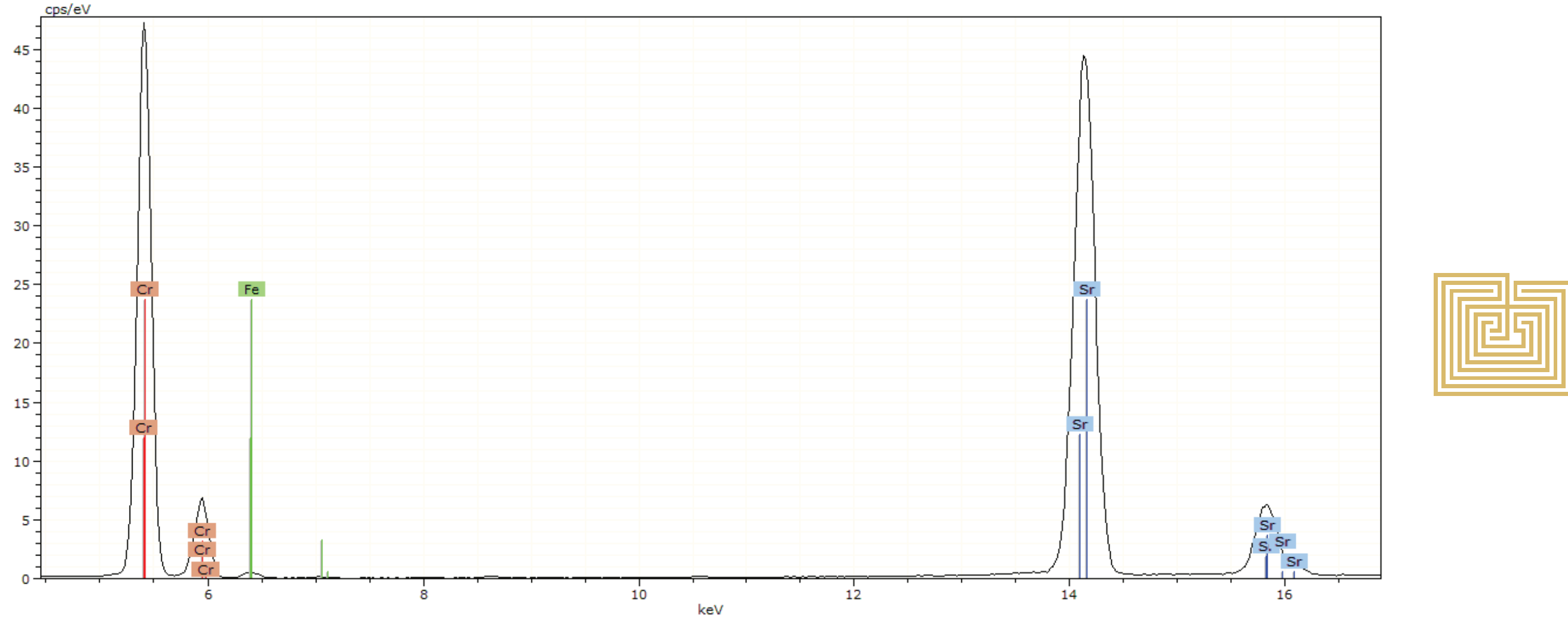

Spektri 3.

Röntgenfluoresenssispektri väriainetuubista, Fritz Behrendt Farbe, behrendgrün hell.

Gallen-Kallelan Museo, Espoo. Gallen-Kallelan Museo, inventaarionumero GKM-4272 Spektri: Kansallisgallerian materiaalitutkimuslaboratorio / Hanne Tikkala. 


\section{Koboltinvihreä}

Koboltinvihreä ${ }^{76}$ on tunnistettu seitsemässä 265:stä tutkitusta teoksesta. ${ }^{77}$ Näistä teoksista neljä on valmistunut 1910 -luvulla tai sen jälkeen. Väriainetuubeista kolmesta tunnistettiin koboltinvihreä. Koboltinvihreä on kemialliselta koostumukseltaan kobolttisinkkioksidia $\left(\mathrm{CoZnO}_{2}\right)$. Koska Gallen-Kallelalla on ollut käytössään sekä sinkkivalkoinen että koboltinsininen, tunnistus tapahtuu polarisaatiomikroskoopin ja röntgenfluoresenssispektrometrin avulla. Tasopolarisoidussa läpivalossa koboltinvihreät partikkelit ovat läpinäkyviä, väri vaihtelee haalean vihreästä vihreään (kuva 6). Partikkelien martio on selvä ja niiden taitekerroin suurempi kuin väliaineen $(>1,662)$. Partikkelikokojakauma on laaja. Partikkelit ovat pyöristyneitä muodostaen usein aggregaatteja keskenään. Ristiin polarisoidussa läpivalossa partikkelit ovat anisotrooppisia ja niissä on havaittavissa oma sinivihreä väri. Koboltinvihreää esiintyy muun muassa Afrikan-matkan aikana valmistuneessa teoksessa Tana river ${ }^{78}$ vuodelta 1909, jossa se on yhdessä kuparivihreän ja hydratoidun kromivihreän kanssa. (Linkki teoskuvaan: https://www.kansallisgalleria.fi/ fi/object/439282)

\section{Smaragdinvihreä}

Gallen-Kallelan tuotannossa on 1800-luvun lopulla selvä piikki smaragdinvihreän ${ }^{79}$ käytössä. Yhteensä se esiintyy väriaineena tai epäpuhtautena 67:ssä 265:stä tutkitusta teoksesta. (kaavio 8) Se on tunnistettu myös yhdestä väriainetuubista, jossa se on seoksena kromikeltaisen kanssa. Smaragdinvihreä on kemialliselta koostumukseltaan kupariasetoarseniittia $\left(\mathrm{Cu}\left(\mathrm{C}_{2} \mathrm{H}_{3} \mathrm{O}_{2}\right)_{2} \cdot 3 \mathrm{Cu}\left(\mathrm{AsO}_{2}\right)_{2}\right)$ ja sitä vastaavia mineraaleja löytyy luonnosta useita. ${ }^{80}$ Tunnistamiseen riittää, että vihreältä värialueelta mitataan röntgenfluoresenssispektri, jossa havaitaan sekä kuparin että arseenin piikit. Polarisaatiomikroskoopilla tarkasteltaessa huomataan, että tasopolarisoidussa läpivalossa partikkelit esiintyvät neulamaisten kiteiden muodostamina sferuleina (kuva 7) tai niiden osina. Partikkelien martio on heikko ja taitekerroin suurempi kuin väliaineen $(>1,662)$. Sferulien koko vaihtelee. Ristiin polarisoidussa läpivalossa partikkelit ovat anisotrooppisia ja niissä on nähtävissä selkeitä interferenssivärejä.

Tätä vihreää väriainetta Gallen-Kallela on suosinut erityisesti ennen Afrikan matkaansa. Smaragdinvihreää on havaittavissa esimerkiksi taiteilijan Kalevala-aiheissa, kuten teoksissa Sammon taonta (1893), Lemminkäisen äiti (1897) ja Kullervon kirous (1899) ${ }^{81}$. Mutta myös muissa symbolistissa teoksissaan hän on sitä käyttänyt: Elämä ja kuolema (1884), Tenhotar (1890) ja Unelmien saari (1897) ${ }^{82}$ sekä Juseliuksen mausoleumin freskojen luonnoksissa: Hävitys (1902), Kuokkamies (1902), Epätoivo (1902), Syksy (1903) ja Kevät (1903) ${ }^{83}$. Väriainetta esiintyy myös Gallen-Kallelan tiettävästi ensimmäisessä öljyvärimaalauksessa Kuutamomaisema vuodelta 188184. (Linkit teoskuviin: https://www.kansallisgalleria.fi/fi/ object/389724, https://www.kansallisgalleria. fi/fi/object/398211, https://www.kansallisgalleria.fi/fi/object/384175).

Smaragdinvihreä voi ikääntyessään menettää väriään tai muuttua ruskeaksi. ${ }^{85} \mathrm{Li}$ säksi sen sisältämä arseeni siirtyy erityisesti kosteuden vaikutuksesta ympäröivien maalikerrosten läpi aina pohjustukseen ja/tai päällimmäiseen lakkakerrokseen saakka. ${ }^{86}$

Gallen-Kallelan teoksista on havaittu myös toistaiseksi tunnistamattomia kuparipitoisia sinisiä ja/tai vihreitä väriaineita. Kuparia esiintyy värialueilla yksinään 23:ssa 265:stä tutkitusta teoksesta ja kahdessa väriainetuubissa. Toisinaan kyseessä voi olla epäpuh- 


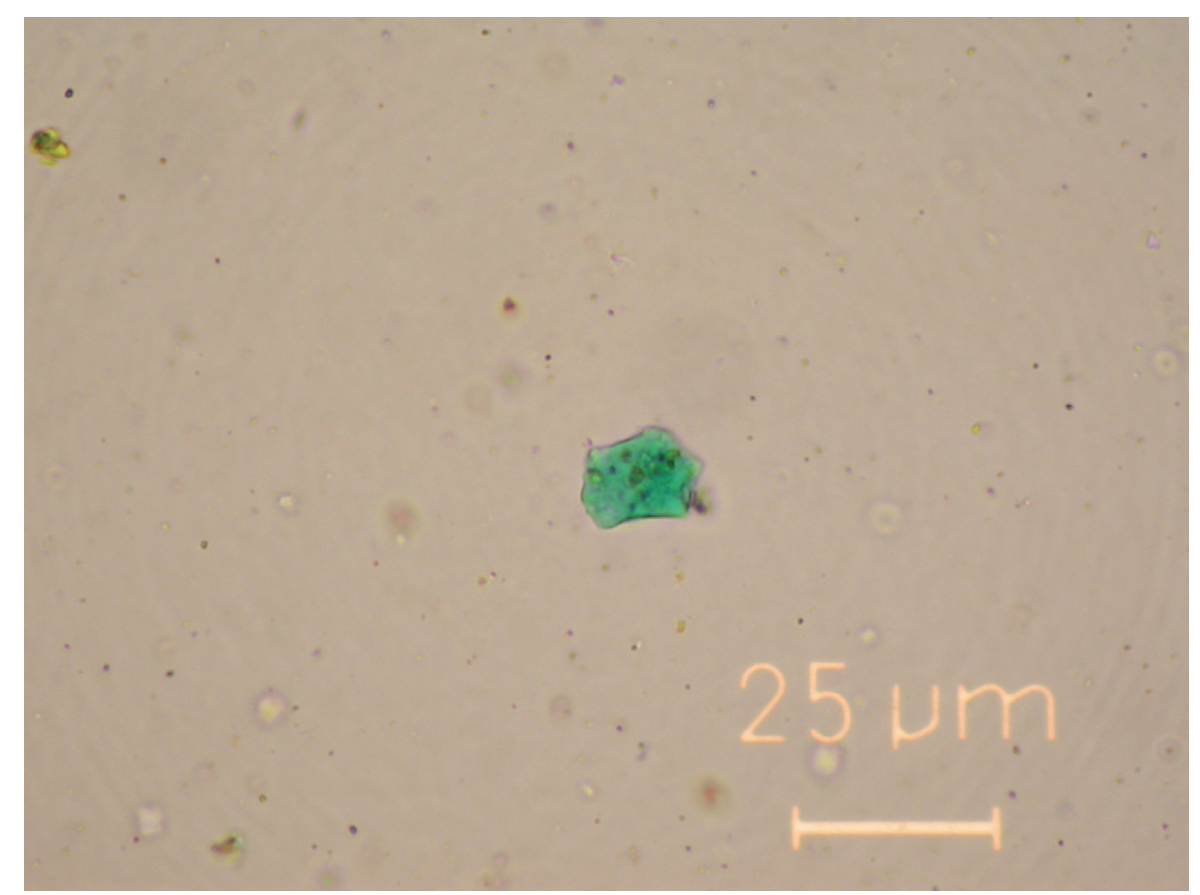

Kuva 6. Hydratoitu kromioksidivihreä -partikkeli tasopolarisoidussa läpivalossa. Näyte teoksesta Akaasiapuu aavikolla, 1909. Öljymaalaus puulle, 17,5 x 13,5 cm. Ateneum, Helsinki. Kansallisgalleria, inventaarionumero A III 2172. Kuva: Kansallisgallerian materiaalitutkimuslaboratorio / Seppo Hornytzkyj. (Linkki teoskuvaan: https://www.kansallisgalleria.fi/fi/object/441056).

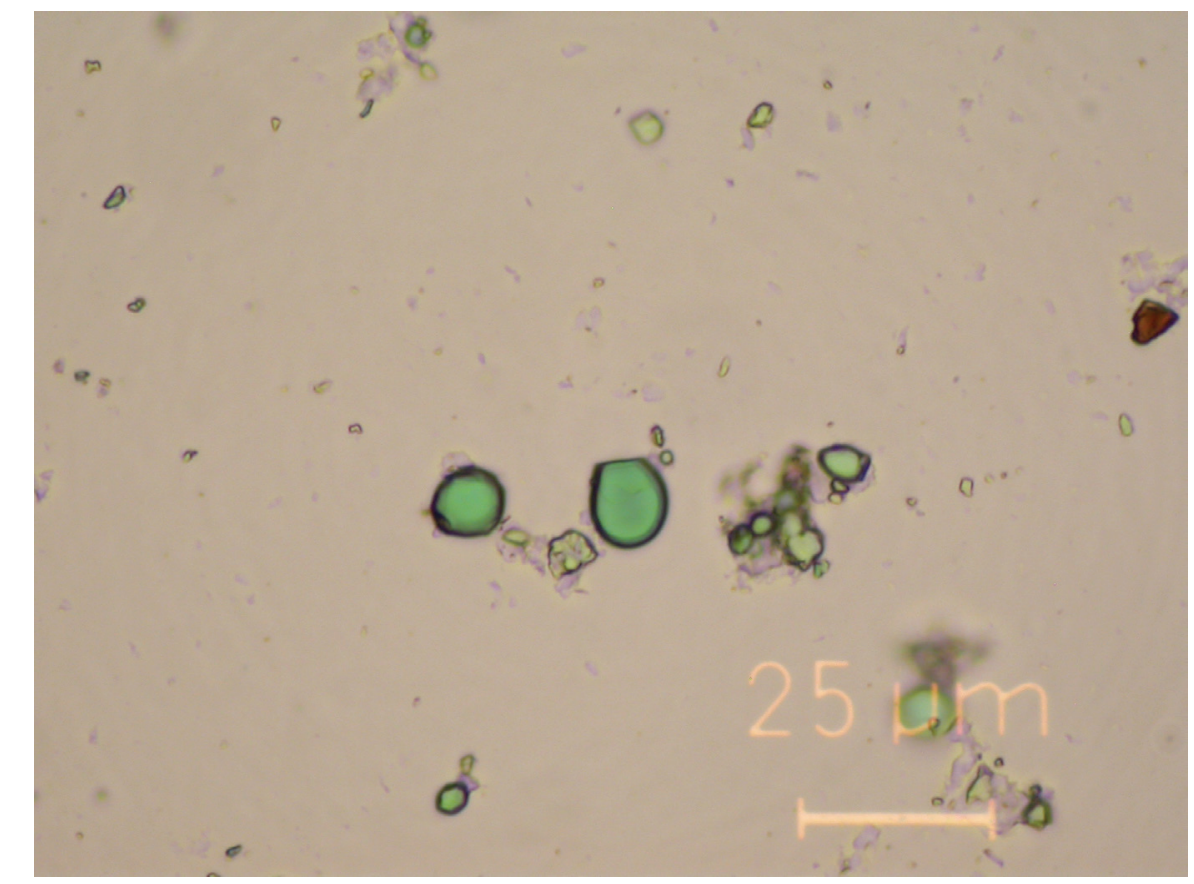

Kuva 7. Koboltinvihreä-väriainepartikkeleita tasopolarisoidussa läpivalossa. Näyte teoksesta Aallottaria, 1909. Öljyväri kankaalle, $53,5 \times 73 \mathrm{~cm}$. Ateneum, Helsinki. Kansallisgalleria, inventaarionumero A-1995-96. Kuva: Kansallisgallerian materiaalitutkimuslaboratorio / Seppo Hornytzkyj. (Linkki teoskuvaan: https://www.kansallisgalleria.fi/fi/object/501754). 
STRONTIUMKELTAINEN

60
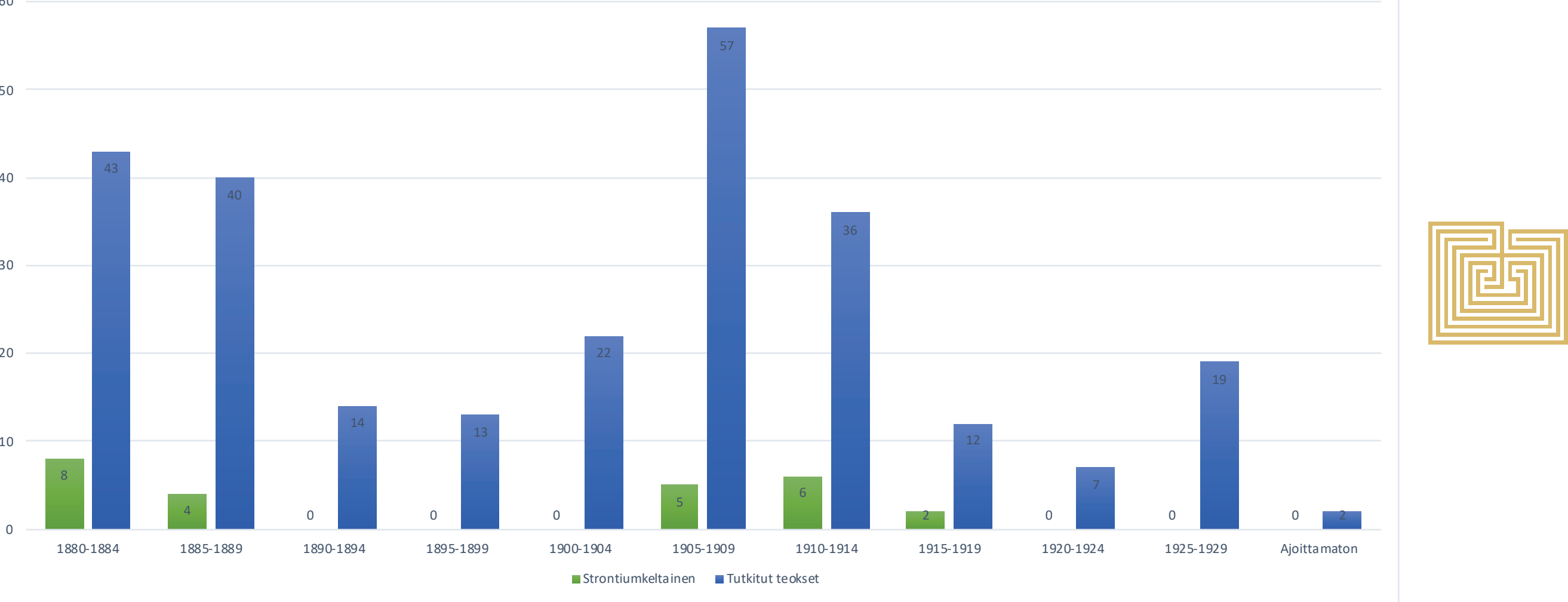

Kaavio 7.

Strontiumkeltaisen esiintyminen teoksissa aikakausittain 


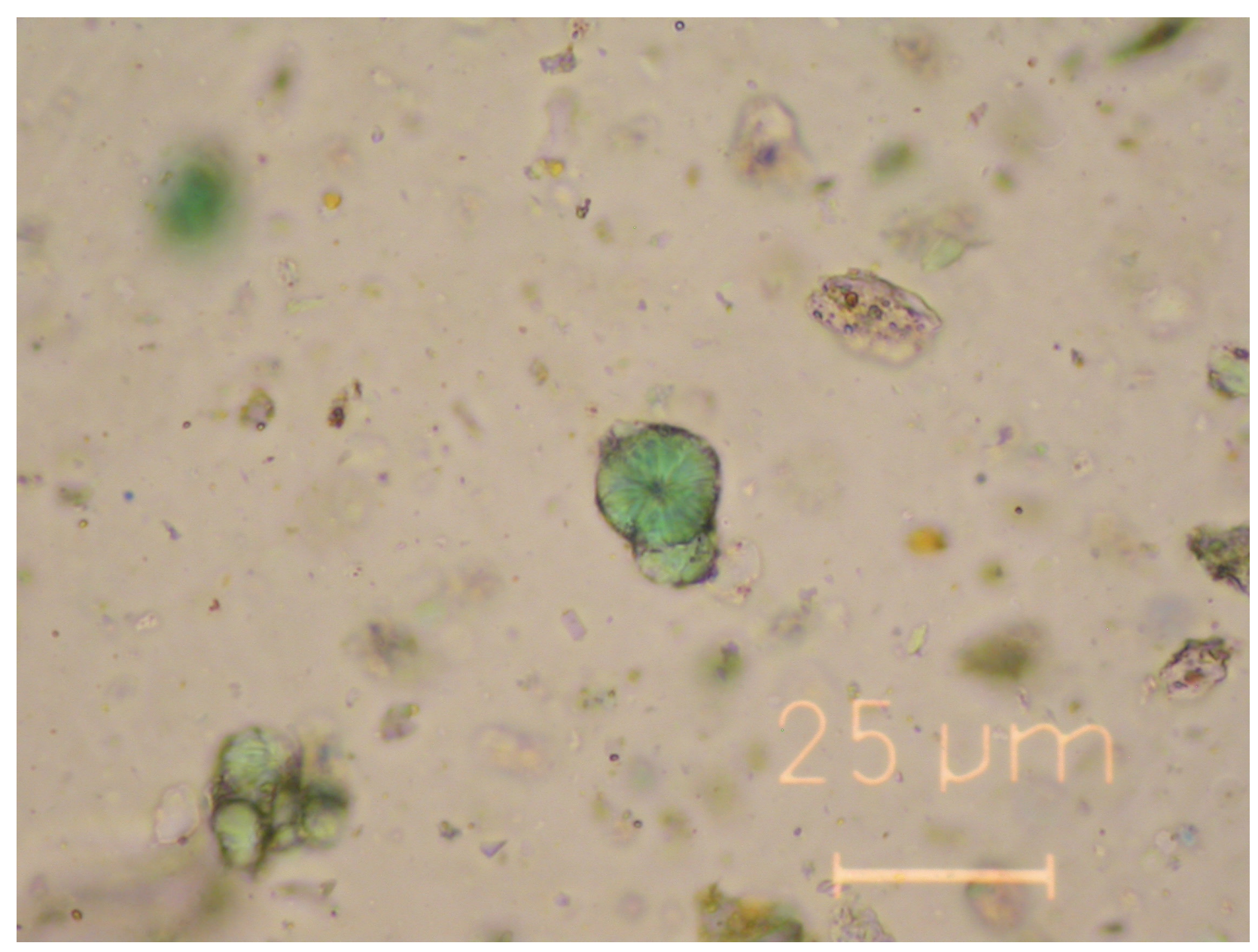

Kuva 8. Smaragdinvihreitä väriainesferuleja tasopolarisoidussa läpivalossa. Näyte teoksesta Kaatunut honka, 1904. Öljymaalaus kankaalle, 30,5 x $22 \mathrm{~cm}$. Serlachius-museot, inventaarionumero 77, Mänttä. Kuva: Kansallisgallerian materiaalitutkimuslaboratorio / Seppo Hornytzkyj. 


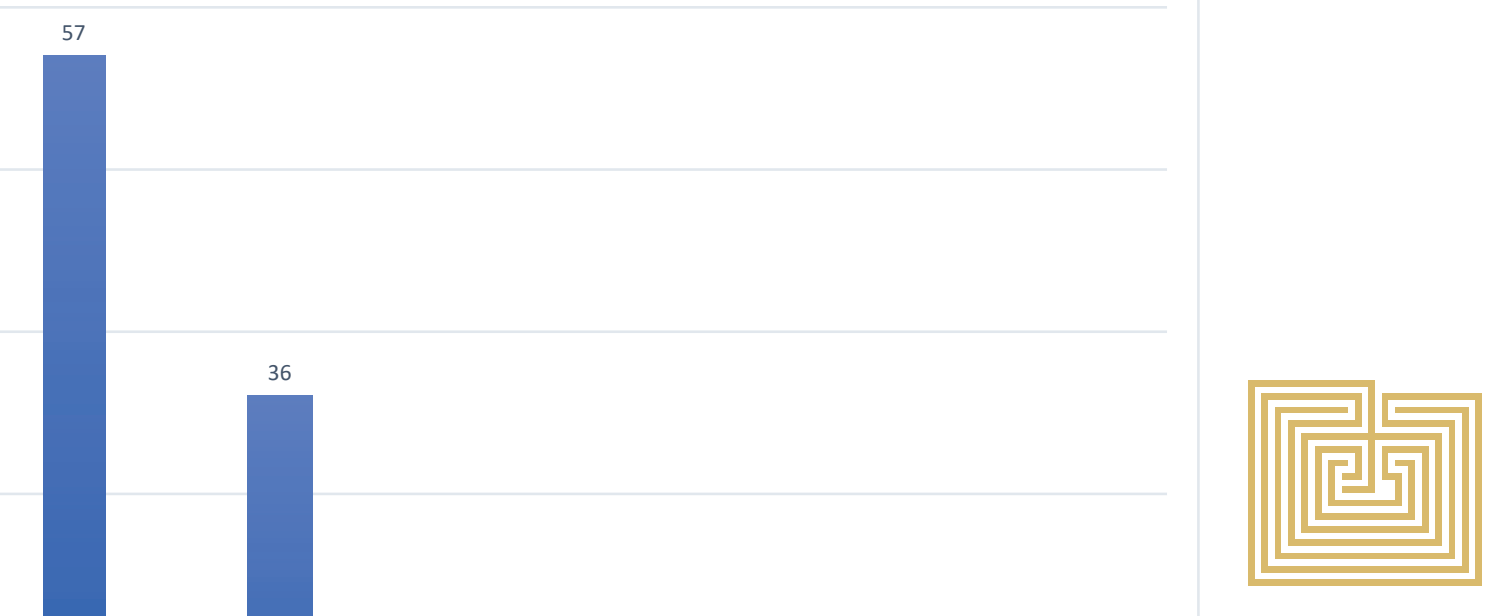

20

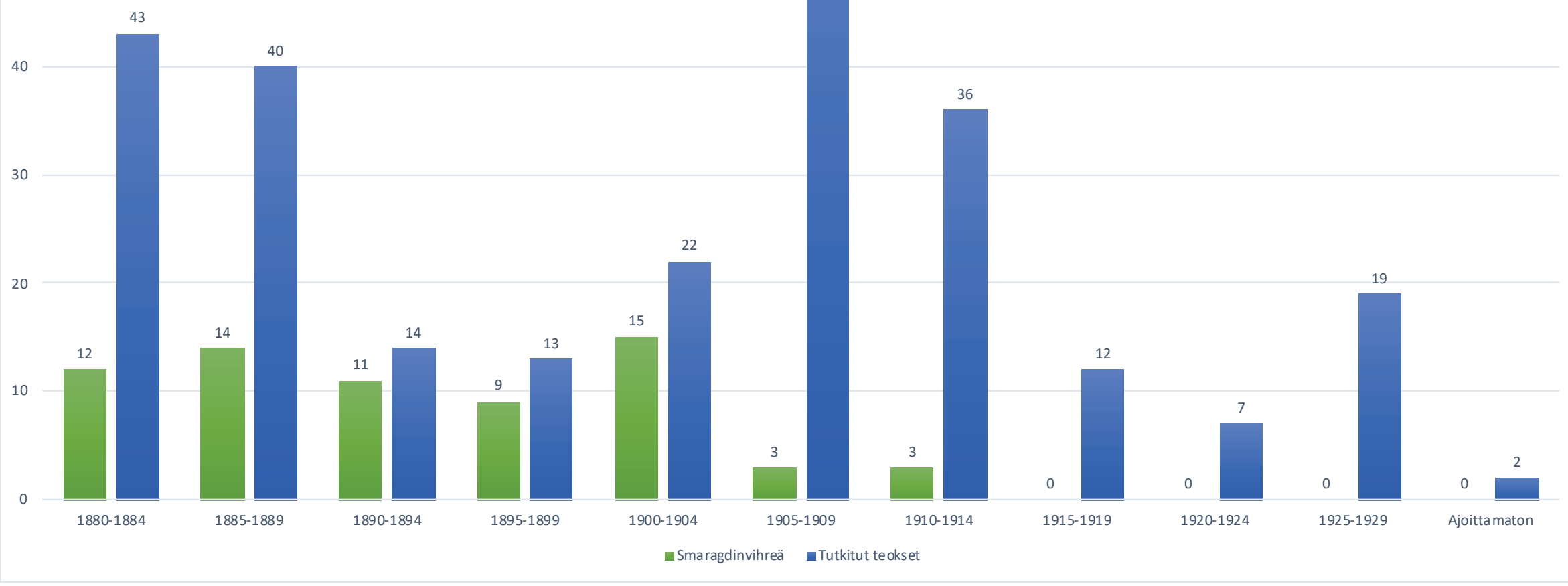

Kaavio 8.

Smaragdinvihreän esiintyminen teoksissa aikakausittain 
taus tai kuivikeaine ${ }^{87}$, mutta on myös teoksia, joissa on kyseessä kuparipitoinen väriaine. Kuten esimerkiksi teoksessa Kylämaisema lampaineen Gallen-Kallelan opiskeluajalta vuodelta $1884^{88}$ ja muotokuvassa Pariisin ajan huonetoveristaan norjalaisesta taiteilija Carl Adam Dörnbergeristä, Bohême (1888) ${ }^{89}$ (Linkki teoskuviin: https://www.kansallisgalleria.fi/fi/object/398619, https://www. kansallisgalleria.fi/fi/object/613434).

\section{Koboltinvioletti}

Gallen-Kallelalla on ollut käytössään ainakin kahta erilaista koboltinviolettia magnesiumkobolttiarsenaattia $\left(\mathrm{Mg}_{2} \mathrm{Co}\left(\mathrm{AsO}_{4}\right)_{2}\right)$ ja kobolttifosfaattia $\left(\mathrm{CO}_{3}\left(\mathrm{PO}_{4}\right)_{2}\right.$.) Näistä magnesiumkobolttiarsenaatti on käytetympi. Se on tunnistettu 19:ssa 265:stä tutkitusta teoksesta, kun taas kobolttifosfaatti on tunnistettu neljästä teoksesta ja yhdestä väriainetuubista. Kahdessa teoksessa kobolttifosfaatti ja magnesiumkobolttiarsenaatti ovat samassa teoksessa. Magnesiumkobolttiarsenaatti on tunnistettu 17:sta vuoden 1905 jälkeen valmistuneesta teoksesta. Kaksi muuta teosta, joista magnesiumkobolttiarsenaatti on tunnistettu, ovat valmistuneet Pariisin vuosina 1888 ja 1889 (Démasquée $^{90}$ ja Karhunput- $\left.k^{91}\right)$. Kobolttifosfaattia sisältävät teokset ovat vuonna 1886 valmistunut Eksynyt ${ }^{92}$ ja vuonna 1900 Ruovedellä maalattu Kalelan kuis$t^{i 3}$. Teokset, joissa on molempia koboltinvioletteja ovat valmistuneet Afrikan matkan yhteydessä vuosina 1909-10 (Donia Sabuk -vuori94 ja Vaivasenpuu aavikolla95). (kaavio 9) (Linkit teoskuviin: https://www.kansallisgalleria.fi/fi/object/390885, https://www.kansallisgalleria.fi/fi/object/468662, https://www. kansallisgalleria.fi/fi/object/448509, https:// www.kansallisgalleria.fi/fi/object/473165, https://www.kansallisgalleria.fi/fi/object/440907, https://www.kansallisgalleria.fi/fi/ object/439311).

Tunnistettaessa magnesiumkobolttiarsenaattia polarisaatiomikroskooppinäytteessä havaitaan pyöreähköjä, pieniä partikkeleita. Ne ovat läpinäkyviä ja sävy vaihtelee orientaation mukaan vaaleanpunaisesta siniviolettiin (kuva 8.). Martio on heikko ja taitekerroin suurempi kuin väliaineen $(>1,662)$. Ristiin polarisoidussa läpivalossa partikkelit ovat anisotrooppisia ja niissä on havaittavissa partikkelin oma violetti väri. Kobolttifosfaatilla partikkelit ovat läpinäkyviä ja niiden sävy vaihtelee orientaation mukaan violetista keltaoranssiin tai siniviolettiin (kuva 9). Mar- tio on selvä ja taitekerroin on suurempi kuin väliaineen $(>1,662)$. Tutkittaessa niitä polarisaattorit ristissä polarisaatiomikroskoopilla havaitaan partikkelien oma kirkkaan violetti väri. Ero näiden kahden väriaineen välillä on havaittavissa hyvin myös röntgenfluoresenssispektrissä. Magnesiumkobolttiarsenaatissa havaitaan koboltin lisäksi selvä arseenin piikki, kun taas kobolttifosfaatissa arseenia ei esiinny. Sen sijaan siinä havaitaan fosforin piikki.

\section{Orgaaniset väriaineet}

Orgaanisia punaisia ja violetteja väriaineita esiintyy tasaisesti läpi koko Gallen-Kallelan tuotannon. (Kaavio 10) Yhteensä 86:ssa 265:stä tutkitusta teoksesta havaittiin erilaisia orgaanisia väriaineita. Niistä 73:ssa väriaine fluoresoi UV-säteilyn vaikutuksesta, joko oranssina tai vaalean punaisena. Tämänkaltainen fluoresenssi viittaa joko karmiinin- tai matarapunaiseen ${ }^{96}$. Myös eosiiniväriaine fluoresoi heikon oranssina ${ }^{97}$. Tässä tutkimuksessa orgaanisia väriaineita ei pyritty tunnistamaan fluoresenssihavaintoa tarkemmin (kuvat 10-12). Orgaanista punaista sisältäviksi merkityistä väriainetuubeista tehdyissä näytteissä ei havaittu 
KOBOLTINVIOLETTI

60

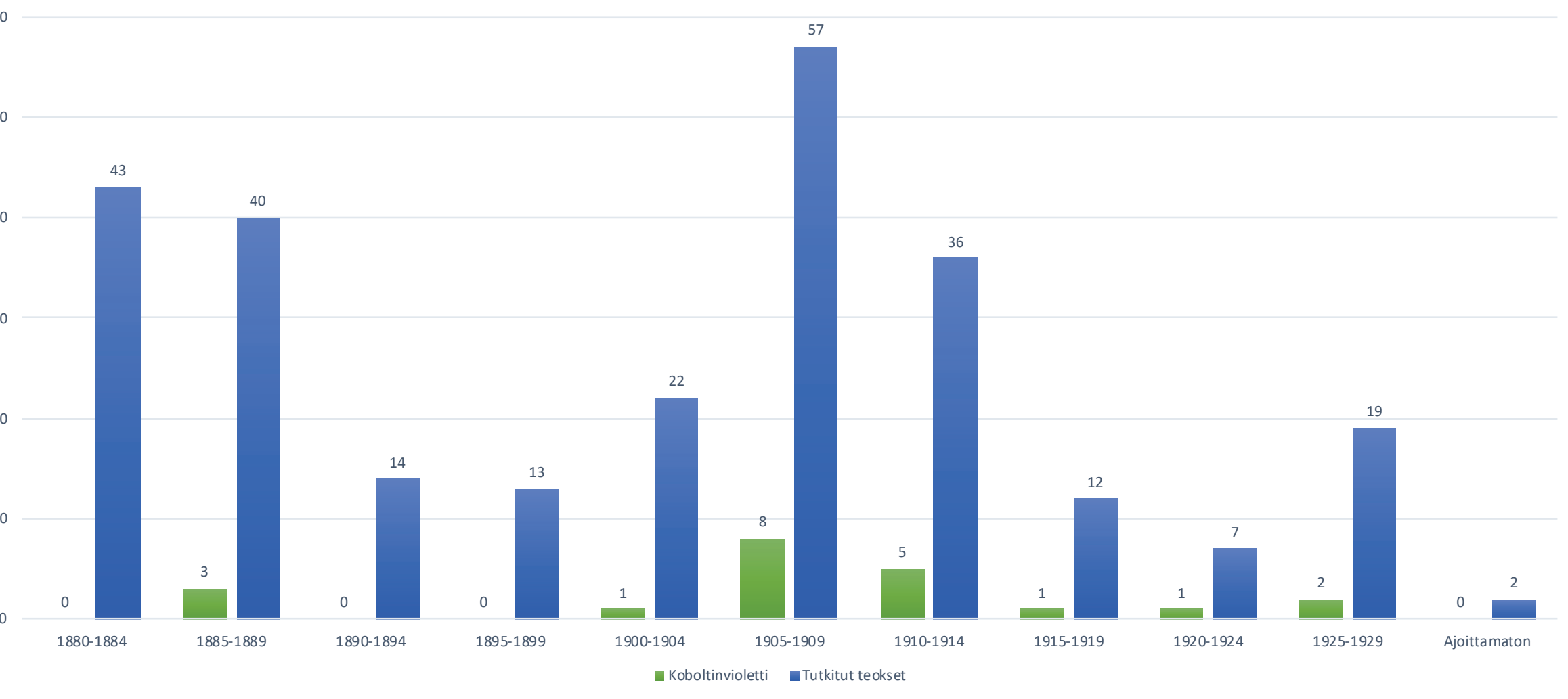

Kaavio 9.

Koboltinviolettien esiintyminen teoksissa aikakausittain 
Kuva 9. Magnesiumkobolttiarsenaatti-partikkeli eri orientaatioissa tasopolarisoidussa läpivalossa. Näyte teoksesta Jokilaakso, 1909. Öljymaalaus puulle, $13,5 \times 17,5 \mathrm{~cm}$. Ateneum, Helsinki. Kansallisgalleria, inventaarionumero A III 2174. Kuva: Kansallisgallerian materiaalitutkimuslaboratorio / Seppo Hornytzkyj. (Linkki teoskuvaan: https://www.kansallisgalleria.fi/fi/ object/430812)
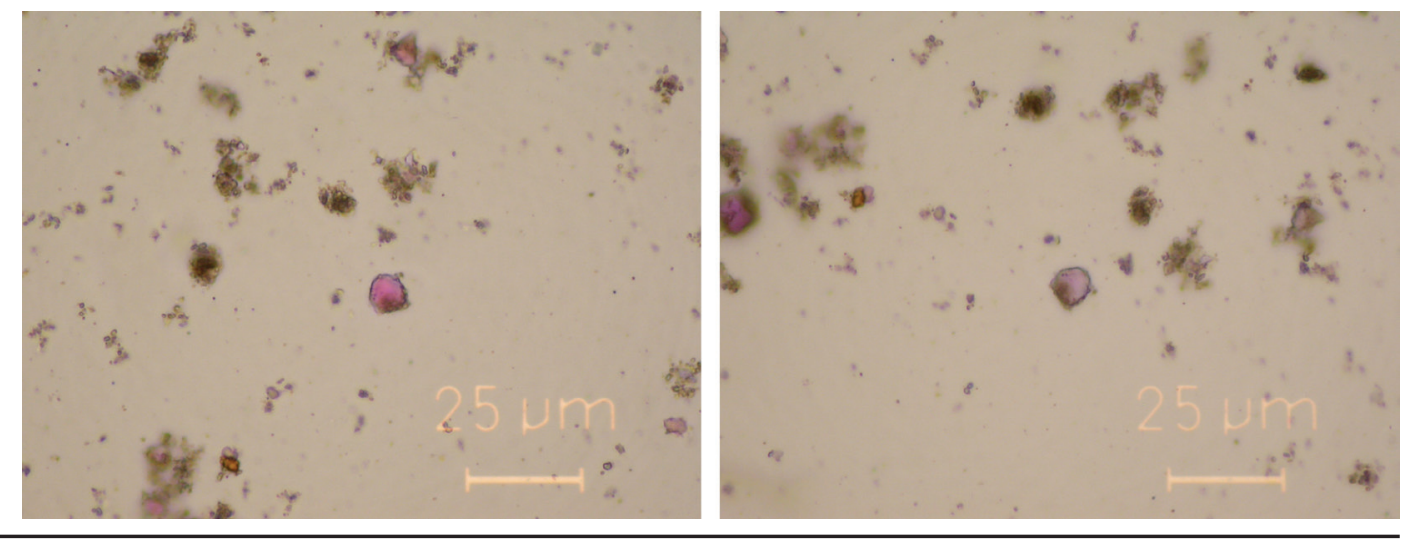

Kuva 10. Kobolttifosfaattipartikkeleita eri orientaatioissa tasopolarisoidussa läpivalossa. Näyte teoksesta Eksynyt, 1886. Öljymaalaus kankaalle, $85 \times 74 \mathrm{~cm}$. Ateneum, Helsinki. Kansallisgalleria, inventaarionumero A III 2224. Kuva: Kansallisgallerian materiaalitutkimuslaboratorio / Seppo Hornytzkyj. (Linkki teoskuvaan: $\underline{\text { htt- }}$ ps://www.kansallisgalleria.fi/fi/object/448509).
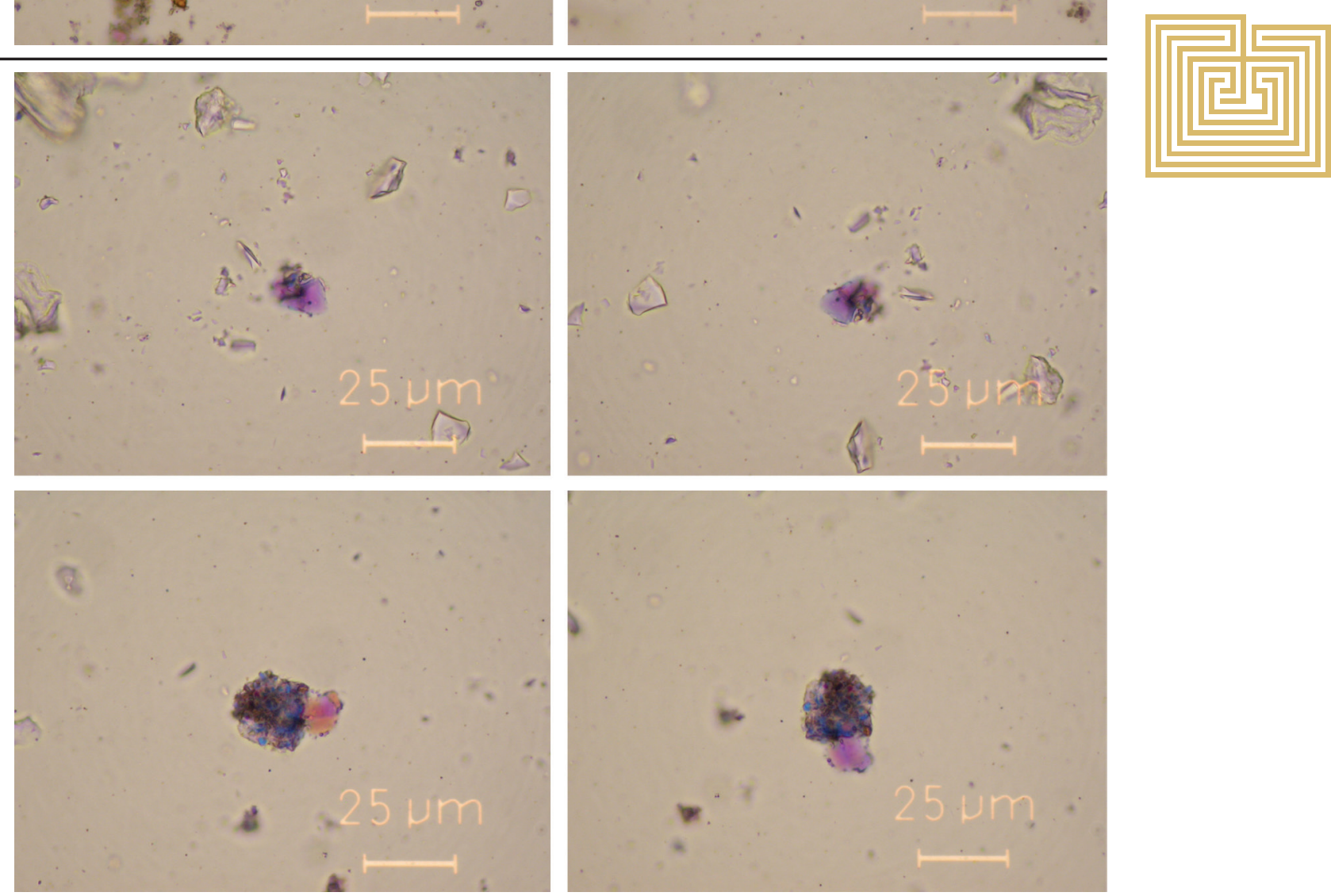


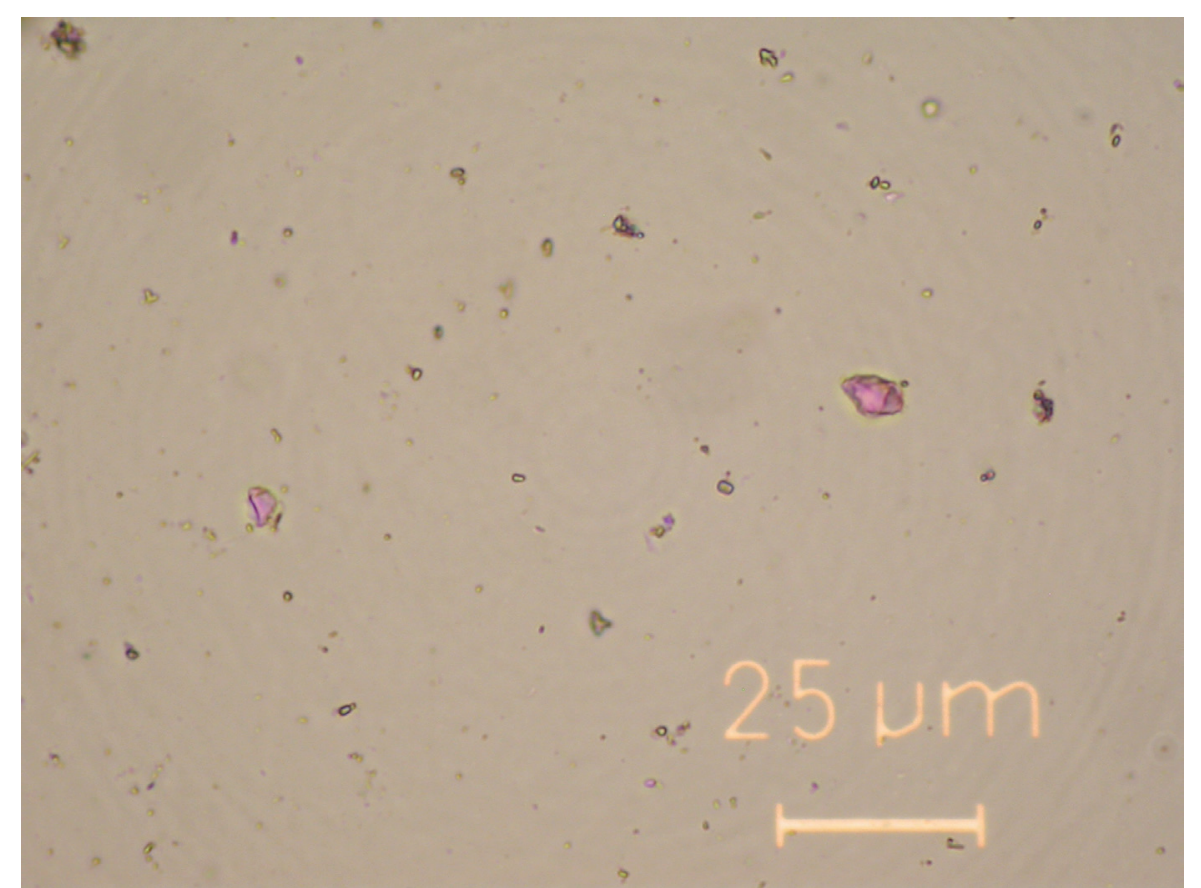

Kuva 11. Orgaaninen punainen väriaine tasopolarisoidussa läpivalossa. Kantajaa ei ole tunnistettu. Näyte teoksesta Iltamaisema, 1899. Guassi, 22,5 x $28 \mathrm{~cm}$. Ateneum, Helsinki. Kansallisgalleria, inventaarionumero A III 2607. Kuva: Kansallisgallerian materiaalitutkimuslaboratorio / Seppo Hornytzkyj. (Linkki teoskuvaan: https://www.kansallisgalleria.fi/fi/object/419134).

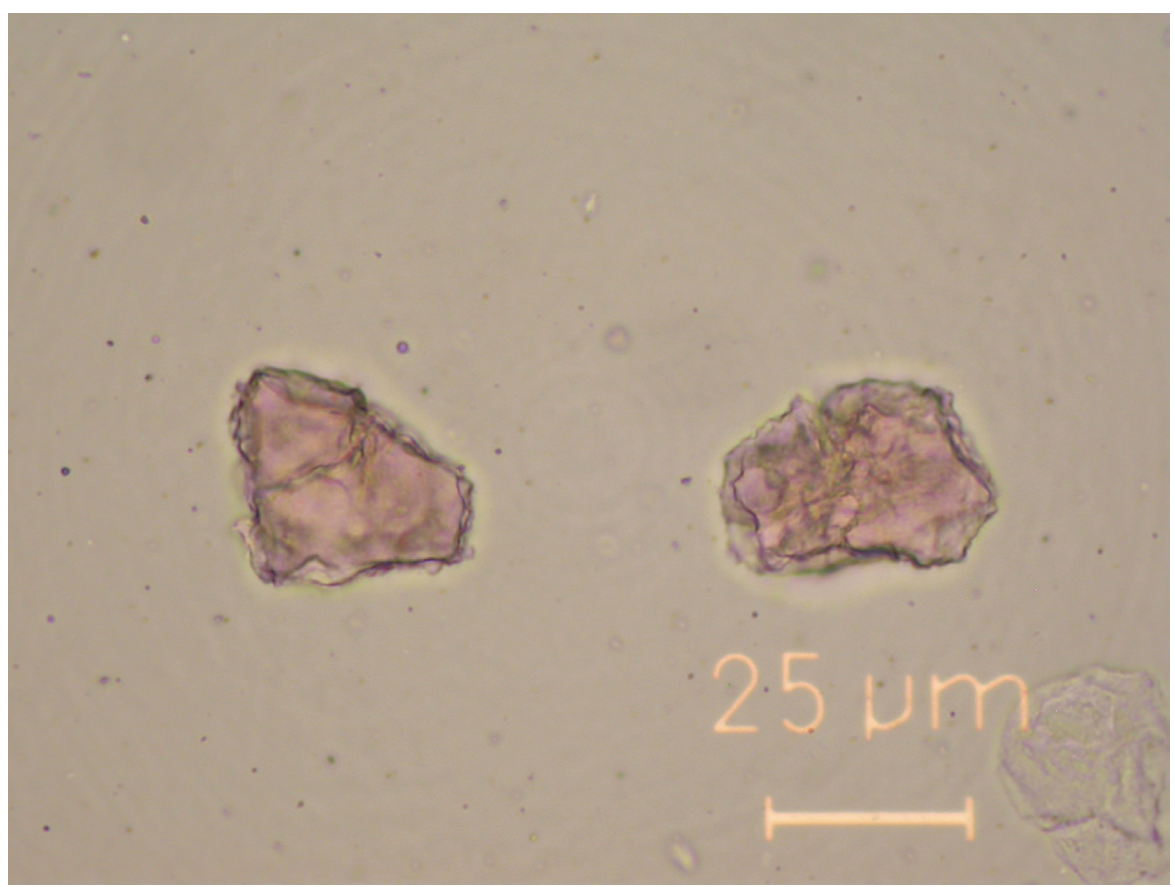

Kuva 12. Orgaaninen punainen väriaine tasopolarisoidussa läpivalossa. Kantajaa ei ole tunnistettu. Näyte teoksesta Karhunputki, 1889. Öljymaalaus kankaalle, 56 x $103 \mathrm{~cm}$. Ateneum, Helsinki. Kansallisgalleria, inventaarionumero A III 2619. Kuva: Kansallisgallerian materiaalitutkimuslaboratorio / Seppo Hornytzkyj. (Linkki teoskuvaan: https://www.kansallisgalleria.fi/fi/object/468662). 
ORGAANISET VÄRIAINEET

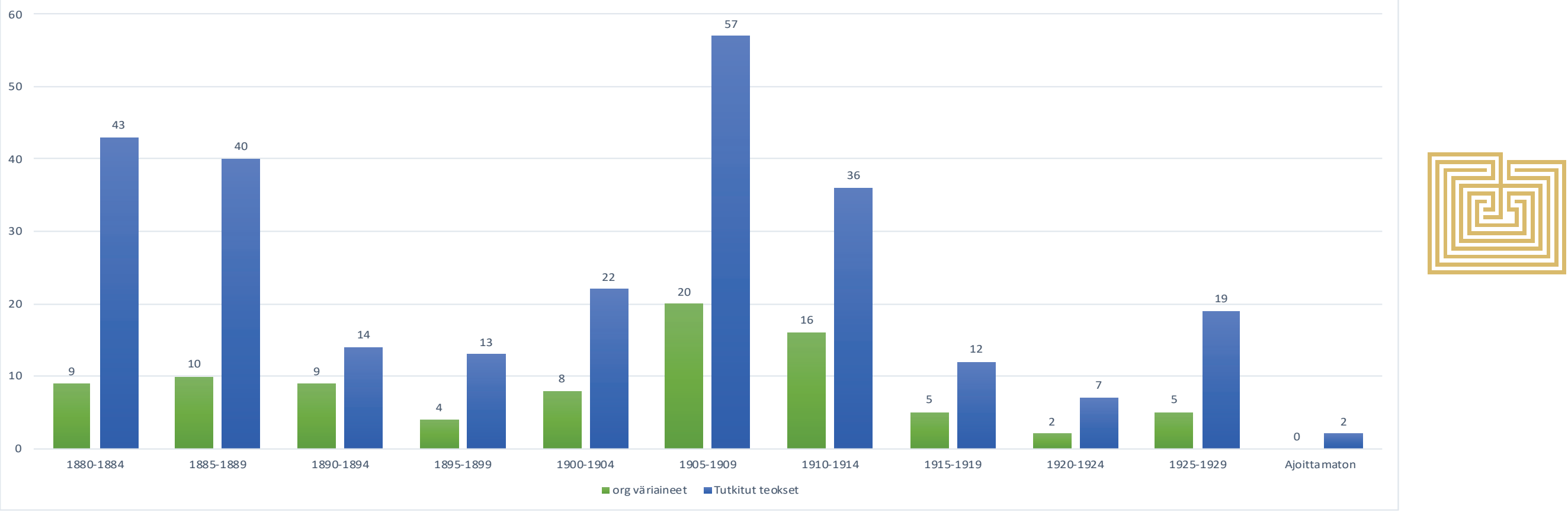

Kaavio 10.

Orgaanisten punaisten väriaineiden esiintyminen aikakausittain. 

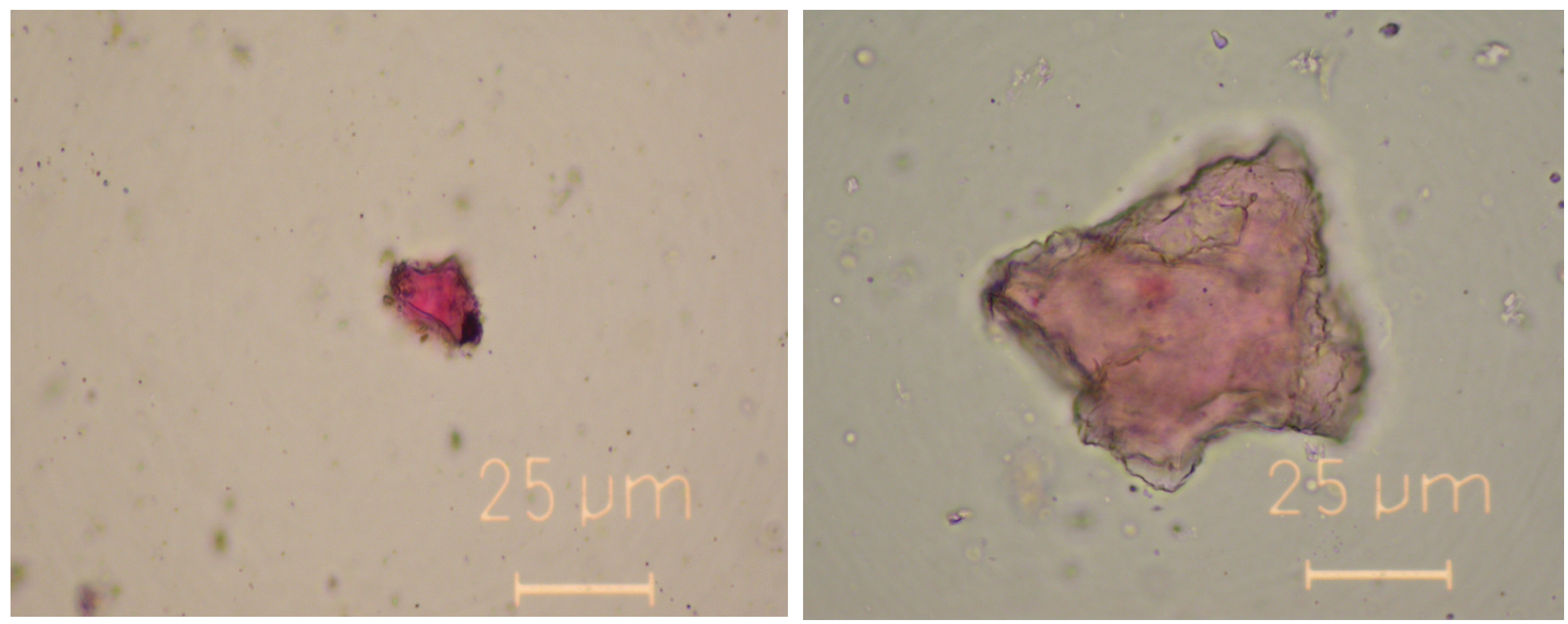

Kuva 13. Orgaaninen punainen väriaine tasopolarisoidussa läpiva- Kuva 14. Orgaaninen punainen väriaine tasopolarisoidussa läpivalossa. Kantajaa ei ole tunnistettu. Näyte teoksesta Seeproja, 1909. lossa. Näyte öljyvärituubista Weimarfarbe, Krapp rosa. GKM-912. Öljymaalaus puulle, 18 × $13 \mathrm{~cm}$. Ateneum, Helsinki. Kansallisgalle- Gallen-Kallelan Museo, Espoo. Kuva: Kansallisgallerian materiaaliria, inventaarionumero A III 2164. Kuva: Kansallisgallerian materi- tutkimuslaboratorio / Seppo Hornytzkyj. aalitutkimuslaboratorio / Seppo Hornytzkyj. (Linkki teoskuvaan: https://www.kansallisgalleria.fi/fi/object/442466). 

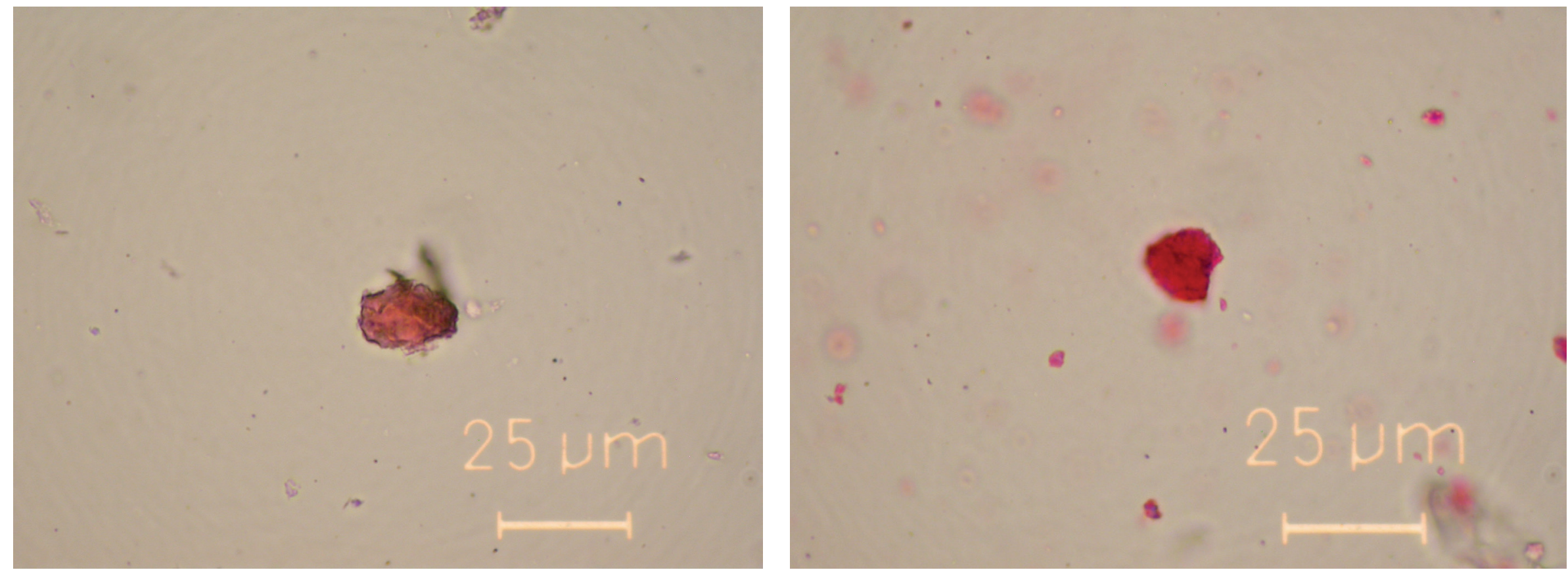

Kuva 15. Orgaaninen punainen väriaine tasopolarisoidussa lä- Kuva 16. Orgaaninen punainen väriaine tasopolarisoidussa läpipivalossa. Näyte temperavärituubista v. Pereiras Temperafarbe, valossa. Näyte öljyvärituubista Alizarine-Madder. GKM-4399. GalKrapplakk (Garance) rosa. GKM-4399. Gallen-Kallelan Museo, len-Kallelan Museo, Espoo. Kuva: Kansallisgallerian materiaalitutkiEspoo. Kuva: Kansallisgallerian materiaalitutkimuslaboratorio / muslaboratorio / Seppo Hornytzkyj.

Seppo Hornytzkyj. 

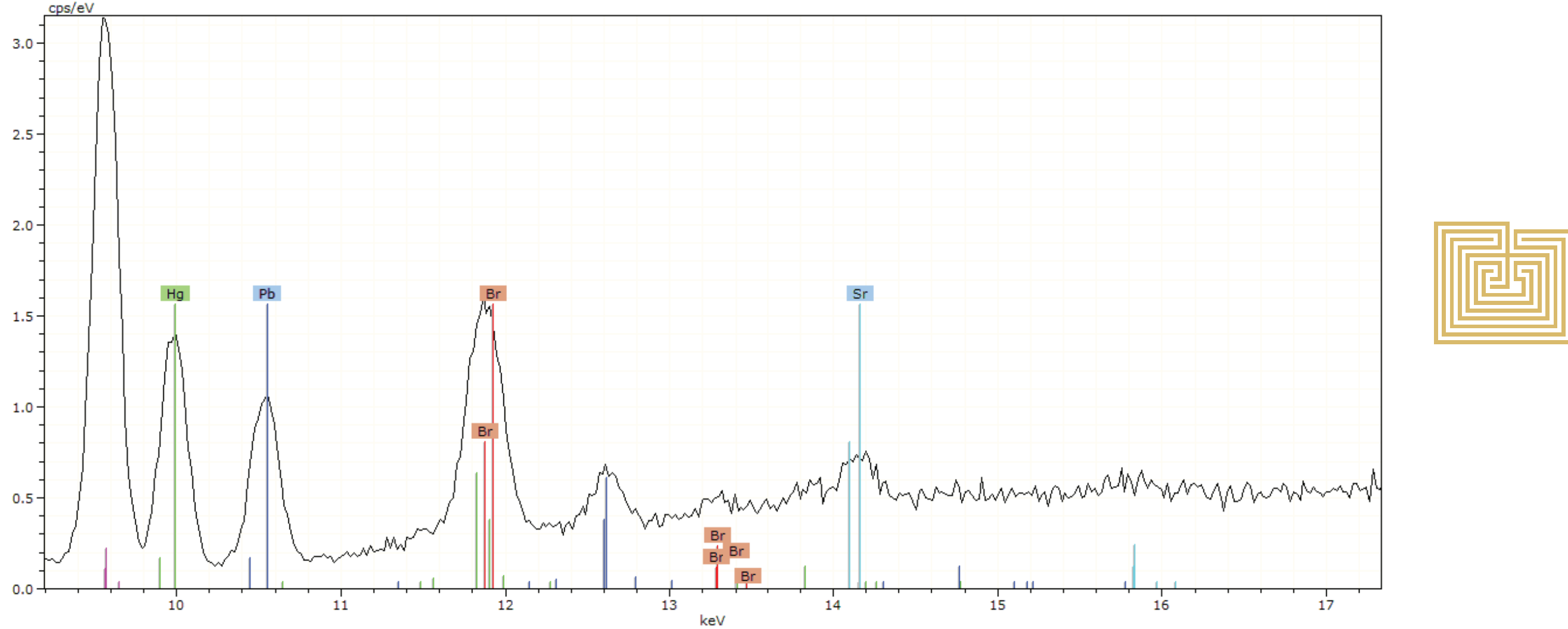

Spektri 4.

Röntgenfluoresenssispektri teoksesta lasimaalausluonnos Talonpojan pytty ja kuninkaan kruunu, 1894 . Guassi paperille, 55 x $38 \mathrm{~cm}$. Gallen-Kallelan Museo, Espoo, inventaarionumero GKM-3462. Spektri: Kansallisgallerian materiaalitutkimuslaboratorio / Hanne Tikkala. 
UV-fluoresenssia, mutta niistä tehdyissä polarisaatiomikroskooppinäytteissä havaittiin orgaanisia väriaineita (kuvat 13-15). Fluoresenssihavaintojen lisäksi kahdesta teoksesta vaaleanpunaisilta värialueilta mitatuissa röntgenspektreissä havaittiin pieni bromin piikki, mikä viittaa eosiiniin ${ }^{98}$ (spektri 4). Orgaanisia keltaisia ei havaittu, mutta niitä voi silti esiintyä Gallen-Kallelan teoksissa. Teosten säilymisen kannalta on huomionarvoista se, että orgaaniset väriaineet menettävät väriään herkästi altistuessaan valolle. ${ }^{99}$ Tästä syystä orgaanisia väriaineita sisältäviä teoksia tulisi tarkkailla, jotta mahdollinen värin haalistuminen havaitaan ajoissa.

\section{Rautaoksidipitoiset väriaineet}

Yksi iso väriaineryhmä, joka esiintyy kaikissa Gallen-Kallelan teoksissa, on erilaiset rautaoksidivärit. Näitä voi teoksissa olla sekä luonnonmineraaleina että synteettisinä väriaineina. Röntgenfluoresenssispektreissä rautaoksidiväreissä havaitaan selvä raudan ja toisinaan myös pieni mangaanin piikki. Mikäli mangaanin piikki on suuri, on kyse umbrasta $^{100}$, joihin myös osa väriainetuubien nimistä viittaa. Väriainetuubien joukossa on myös pelkkää rautaa sisältäviä rautaok- sidivärejä. Toisinaan rautaoksidiväreistä mitatuissa röntgenfluoresenssispektreistä on mangaanin lisäksi havaittavissa pieni titaanin ja kaliumin piikki, joka johtuu luonnon mineraaliväriaineiden epäpuhtauksista. Kahdessa siennaksi nimetystä väriainetuubista mitatussa röntgenfluoresenssispektrissä havaittiin raudan lisäksi selvä arseenin piikki. Arseenin alkuperää ei vielä tunnistettu.

\section{Harvoin esiintyvät väriaineet}

Seuraavassa listassa on esitelty väriaineet, joita esiintyy Gallen-Kallelan teoksissa ja väriainetuubeissa hyvin harvoin. Tämä voi johtua siitä, että niitä ei ole ollut usein käytössä tai että niitä ei ole voitu tunnistaa teoksista ilman näytteenottoa.

Kromioksidivihreä (kuva 16) on tunnistettu yhdestä väriainetuubista, jossa se on seoksena hydratoidun kromioksidivihreän ja synteettisen ultramariinin kanssa. ${ }^{101}$

Maavihreä on tunnistettu yhdestä teoksesta (Karjalainen nainen vuodelta 1891; kuva 17). ${ }^{102}$ (Linkki teoskuvaan: https://www. kansallisgalleria.fi/fi/object/399987).

Lyijypunainen on tunnistettu varmuudella kahdesta teoksesta (Bohême, Carl Adam Dörnberger vuodelta 1888 ja Mies saunan ulkopenkillä vuodelta 1889) ja kolmesta väriainetuubista. ${ }^{103}$ (Linkki teoskuvaan: https:// www.kansallisgalleria.fi/fi/object/398619).

Napolinkeltainen on tunnistettu kahdesta melko varhaisen tuotannon teoksesta keltaiselta värialueelta (Luminen pihamaa vuodelta 1882 ja Kuusia karjapihassa vuodelta 1887). ${ }^{104}$ (Linkit teoskuviin: https://www.kansallisgalleria.fi/fi/object/472551, https://www. kansallisgalleria.fi/fi/object/616549).

Koboltinkeltainen on tunnistettu yhdestä Afrikan aikaisesta teoksesta (Akaasiapuu aavikolla vuodelta 1909) ja yhdestä väriainetuubista, joissa se on osana vihreää seosta. ${ }^{105}$ Koboltinkeltaista pidetään melko epästabiilina väriaineena, erityisesti öljysideaineessa tai seoksissa orgaanisten väriaineiden kanssa. ${ }^{106}$ (Linkki teoskuvaan: https:// www.kansallisgalleria.fi/fi/object/441056).

Titaanivalkoinen tunnistettiin kolmesta teoksesta, jotka kaikki on maalattu Amerikassa oleskelun aikana 1920-luvulla (Mrs Margaret Lippo Hecht ja tytär Margareta, kaksoismuotokuvaluonnos, Mrs Hecht, muotokuvaluonnos ja Intiaani ratsain). ${ }^{107}$ (Linkki teoskuvaan: https://www.kansallisgalleria.fi/ fi/object/440830).

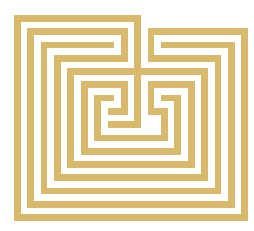



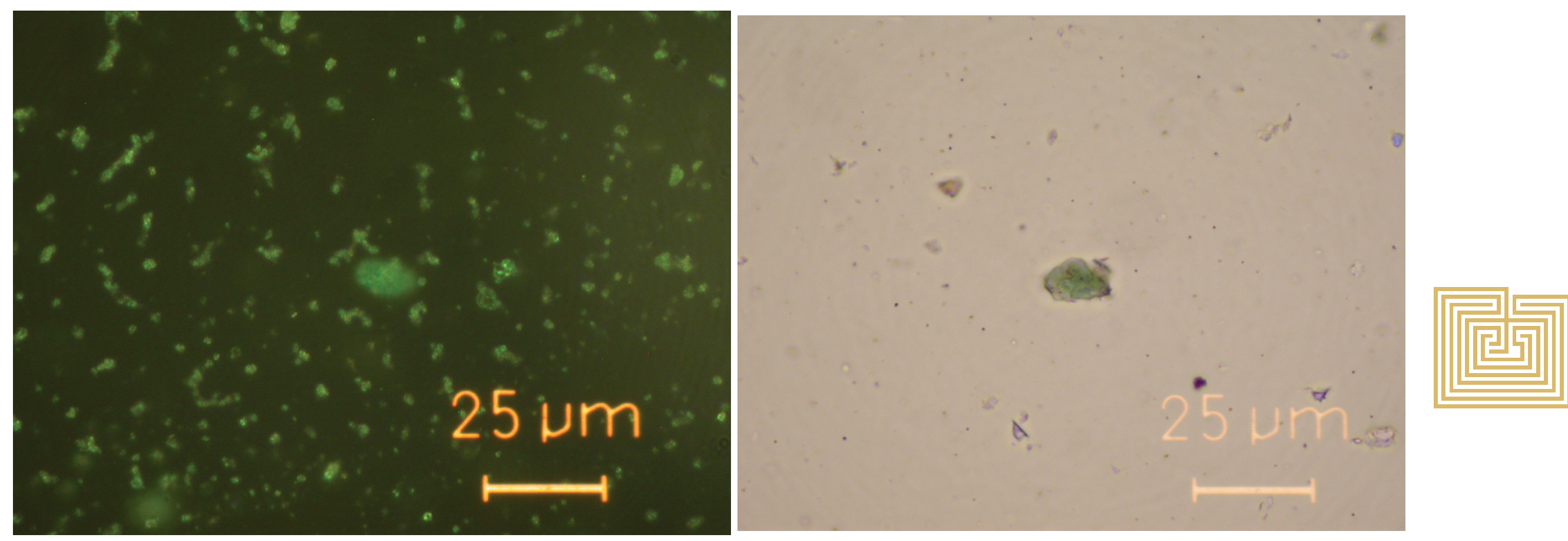

Kuva 17. Kromioksidivihreän partikkeliaggregaatteja kuvattuna ris- Kuva 18. Maavihreä väriainepartikkeli kuvattuna tasopolarisoitiin polarisoidussa pintavalossa. Näyte väriainetuubista Wilh. Becker dussa läpivalossa. Näyte teoksesta Karjalainen nainen, 1891. Chromoxidgrönt, GKM-898. Gallen-Kallelan Museo, Espoo. Kuva: Öljyväri kankaalle, 39 x 31 cm. Ateneum, Helsinki. KansallisgalKansallisgallerian materiaalitutkimuslaboratorio / Seppo Hornytzkyj.

leria, inventaarionumero A II 1254:56. Kuva: Kansallisgallerian materiaalitutkimuslaboratorio / Seppo Hornytzkyj. (Linkki teoskuvaan: https://www.kansallisgalleria.fi/fi/object/399987) 


\section{Loppupäätelmät}

Akseli Gallen-Kallelan väriainepaletti on tyypillinen 1800-1900-lukujen vaihteen taiteilijan väriainepaletti. Tästä huolimatta se sisältää yksilöllisiä piirteitä, jotka voivat toimia Gallen-Kallelan teosten attribuoinnin, ajoituksen ja aitoustutkimusten työkaluna. Paletti sisältää myös väriaineita, jotka muuttuvat altistuessaan esimerkiksi valolle tai kosteudelle.

Keltaisina väreinään Gallen-Kallela on käyttänyt kadmium- ja kromikeltaista sekä rautaoksidikeltaista. Sivupaletissaan hänellä on käytössään strontiumkeltainen, joka ei tutkimusaineistossa esiinny yksin keltaisella värialueella vaan aina vihreällä. Teoksista ja tuubeista on tunnistettu kaksi keltaista, joista toinen, koboltinkeltainen, esiintyy vain yhdessä teoksessa ja yhdessä väriainetuubissa osana vihreää väriaineseosta. Toinen, napolinkeltainen, esiintyy pienellä keltaisella alueella kahdessa kohtalaisen varhaisessa teoksessa.

Punaisena värinä on lähes jokaisessa teoksessa käytetty sinooperia. Hyvin useasta teoksesta on tunnistettu myös punaista rautaoksidia ja orgaanisia punaisia väriaineita. Teoksissa ja väriainetuubeissa on myös lyijypunaista. Oranssi on joko kadmiumoranssia tai seos sinooperista tai rautaoksidipunaisesta ja kadmium- tai rautaoksidikeltaisesta.

Sinisistä ylivoimaisesti eniten Gallen-Kallela on käyttänyt koboltinsinistä. Myös synteettistä ultramariinia, preussinsinistä ja seruleeninsinistä on tunnistettu teoksista ja väriainetuubeista. Violetit värit ovat usein seoksia koboltinsinisestä tai synteettisestä ultramariinista ja sinooperista tai orgaanisesta punaisesta. Erityisesti vuoden 1905 jälkeen hän on käyttänyt violettina myös kahta erilaista koboltinviolettia. Koboltinvioletit saattavat esiintyä teoksessa myös yhdessä. Käytössä on ollut myös orgaaninen violetti väriaine, jota ei ole tämän tutkimuksen yhteydessä karakterisoitu.

Vihreänä väriaineena Gallen-Kallela on usein käyttänyt hydratoitua kromioksidivihreää. Osassa teoksista on koboltinvihreää ja 1800-luvun lopussa hän on suosinut smaragdinvihreää. Yhdestä teoksesta on tunnistettu myös maavihreä, joka voi paletissa olla hyvinkin yleinen väriaine. Vihreä voi olla myös seos erilaisista sinisistä, keltaisista ja vihreistä.

Väripaletin mustat väriaineet ovat rautaoksidi- ja luumustaa. Myös seoksia eri väriai- neista on käytetty. Näitä seoksia ovat muun muassa seokset, jotka sisältävät rautaoksidivärejä, koboltinsinistä, sinooperia ja hydratoitua kromioksidivihreää tai rautaoksidivärejä, synteettistä ultramariinia ja hydratoitua kromioksidivihreää. Valkoisista lyijy- ja sinkkivalkoinen ovat huomattavasti suosituimmat. Teoksissa voi olla valkoisena värinä tai pohjusteessa pelkästään lyijyvalkoista, mutta ei koskaan pelkästään sinkkivalkoista. Lisäksi useassa teoksessa on bariumsulfaattia tai litoponia sekä kalsiumkarbonaattia. Nämä ovat toimineet luultavimmin täyteaineina tai orgaanisten väriaineiden kantajina. Amerikassa viettämänsä ajanjakson aikana 1920-luvulla Gallen-Kallela on käyttänyt satunnaisesti myös titaanivalkoista.

Gallen-Kallelan tuotannon väriainetutkimuksen perusteella huomion voi kohdentaa edelleen teosten värien säilymisen kannalta oleellisiin jatkotutkimuksiin. Esimerkiksi taiteilijan käyttämien kadmiumyhdisteiden lisätutkimuksen perusteella voi arvioida, onko niiden joukossa sellaista yhdistettä, joka aiheuttaa ympäröivän öljysideaineen heikentymistä. Keltaisen lyijykromaatin kiderakenteen tutkimuksella voi päästä selville pitääkö se värinsä vai haalistuuko tai tummuuko se 
ajan kuluessa. Orgaanisten väriaineiden yksityiskohtaisempi tunnistaminen lisää tietoa niiden alttiudesta haalistumiselle. Jos teoksissa on näiden väriaineiden herkästi reagoivia muotoja, voidaan tämä ottaa huomioon teosten käsittelyssä, säilyttämisessä ja valaistuksen voimakkuudessa. Erityisesti arseenipitoisten yhdisteiden tunnistaminen teoksista on myös työturvallisuuteen liittyvä tieto.

Gallen-Kallelan väriainepaletissa on myös aiheita taiteilijaväriaineiden käytön historian syventävään tutkimukseen. Näitä ovat esimerkiksi titaanivalkoisen varsin varhainen esiintyminen Amerikan ajanjaksolla valmistuneissa teoksissa ja toistaiseksi vielä tunnistamattomien kupariyhdisteiden tunnistaminen. Kun muutosherkät väriaineet on teoksista tunnistettu, voidaan ne ottaa huomioon teosten käsittelyssä sekä esittämis- ja säilytysolosuhteissa ja näin turvataan värien säilyminen mahdollisimman muuttumattomina. Tämän seurauksena museokävijät saavat nauttia pidempään teoksista sellaisina kuin taiteilija on ne halunnut esittää.

\section{Viitteet}

1 Akseli Gallen-Kallelan itsensä kirjoittama maininta käyttämästään preussinsinisestä teoksen Talvimaisema Jaatsissa (1882) taustapuolella. Teos kuuluu Gallen-Kallelan Museon kokoelmiin inventaarionumerolla GKM-322.

2 Marja Lahelma, Ateneumin taiteilijat. Akseli GallenKallela (Helsinki: Kansallisgallerian julkaisuja, 2018), 11.

3 Marja-Terttu Kivirinta, "Myyttinen pantterimies ja 1900-luvun ekspressionismi", teoksessa Ota sielusi täyteen! Tutkimuksellisia polkuja Akseli GallenKallelan taiteeseen. (Helsinki: Gallen-Kallelan Museo, 2011), 108.

4 Helmiriitta Sariola, "In Africa", teoksessa Akseli Gallen-Kallela, näyttelyjulkaisu 16.2.-26.5.1996 Ateneum ja 26.6.-1.9.1996 Turun Taidemuseo, toimittaneet Leena Ahtola-Moorhouse, Heikki Malme, Sirkka Liisa Muittari ja Outi Alatalo-Pöllänen (Helsinki: F. G. Lönnberg 1996), 82.

5 Rolf Nummelin, "Maalaustaiteen uusia virtauksia", teoksessa Suomen taiteen historia, toimittaneet Bengt von Bonsdorff, Carl Jackob Cardberg, Bo Lindberg, Erik Kruskopf, Rolf Nummelin, Sixten Ringbom, Åsa Ringbom ja Mona Schalin (Helsinki: Schildts Kustannus Oy, 1998), 245.

6 Hänen tiedetään asuneen ja matkustelleen yksin ja perheensä kanssa Ranskassa, Venäjällä, Unkarissa, Italiassa, Espanjassa, Afrikassa, Meksikossa ja Yhdysvalloissa.

7 Merkkejä ovat Beckmann's Syntons-Farben, Bernhard Kahn \& Co. (Kölner Farben Fabrik), Fritz Behrendt Farbe, Beckers Normalfärger AB., Dr. Fr. Schoenfeld \& Co., v. Pereira's Temperafarbe, Reynolds \& Co. Inc., H. Schmincke \& Co., Lefranc, Weimarfarbe, Sadolins farven, J.Blockx Fils á vieuxdieu, Hienoimmat öljyvärit, Pelikanfarbe, Talens ja G.Rowney \& Co.

8 Suomessa on tutkittu 1980-luvulla Lucas

Cranach vanhemman Suomessa olevien teosten väriaineita. Samaan aikaan tutkittiin myös Alexander
Lauréuksen ja Vincent van Goghin teosten väriaineita. Laajempia tutkimuskokonaisuuksia ovat 2000-luvun alussa tehty tutkimus Isaac Wacklinin tuotannon väriaineista sekä toinen vuonna 2008 julkaistu tutkimus koskien Ole Kandelinin tuotannon väriaineista. Ensimmäinen Akseli Gallen-Kallelan tuotantoon kohdistunut rakenne- ja materiaalitekninen tutkimuskokonaisuus on tehty 1990-luvulla teokselle Lemminkäisen äiti (https://www.kansallisgalleria.fi/fi/ object/398211). Näiden lisäksi nykyisen Metropolia -ammattikorkeakoulun konservaattoriopiskelijoiden lopputyöprojektien yhteydessä on tutkittu tapauskohtaisesti eri taiteilijoiden mm. Adolf von Beckerin väriaineita.

9 Ari Tanhuanpää. Huoli kuvasta - Merkitys, mieli, materiaalisuus. (Jyväskylä: Jyväskylän Yliopisto, 2017), 116

10 John van Asperen de Boer, "Some Reflections Upon the Impact of Scientific Examination on Art Historical Research". Teoksessa Looking through paintings. The Study of Painting Techniques and Materials in Support of Art Historical Research. (Lontoo: Archetype Publications ja Baarn: Uitgeverij de Prom, 1998), 15.

11 Esimerkiksi Vincent van Goghilta on tunnistettu erikseen Hollannin ja Ranskan aikojen paletit, joiden jälkeen on tutkittu syvemmin yksittäisten väriaineiden (eosiini ja koboltinsininen) ominaisuuksia. Marija Vellekoop, Muriel Geldof, Ella Hendriks, Leo Jansen ja Alberto de Tagle. Van Gogh's Studio Practices. (New Haven ja Lontoo: Van Gogh Museum ja Mercatorfonds, Yale University Press, 2013), 226289.

12 Gunnar Heydenreich. Lucas Cranach the Elder: Painting Materials, Techniques and Workshop Practice. (Amsterdam: University Press,2007). 13 Ensimmäiset Jan Vermeerin töihin keskittyvät tekniset- ja materiaalitutkimukset on tehty jo 1960-luvulla ja tutkimustyötä on jatkettu tähän päivään saakka. Lisää tietoa linkeistä: https://www. nationalgallery.org.uk/research/about-research/the-

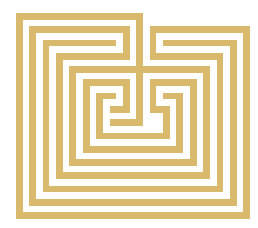


meaning-of-making/vermeer-and-technique/vermeerspalette ja https://www.mauritshuis.nl/en/discover/ exhibitions/the-girl-in-the-spotlight/ ).

14 Lugina, V. ja Tsitovitch, V. "Grounds and Pigments in I. K. Aivazovsky's Painting, New Data." IV Scientific Conference. Expertise and Attribution of Works of Fine Arts, 27.-30.11.2000. Preprints. Magnum Ars Corporation, Moscow, 2002.

15 Teoksista on mitattu 2120

röntgenfluoresenssispektriä ja

polarisaatiomikroskopianäytteitä otettiin 58

teoksesta. Tarvaspään ateljeekodin irtaimistoon

kuuluvista väriainetuubeista on mitattu yhteensä

163 röntgenfluoresenssispektriä ja 39 väriainetuubin sisällöstä tehtiin polarisaatiomikroskooppinäytteet. 16 Öljyvärien säilytykseen sopivat tinatuubit kehitti amerikkalainen taiteilija John G. Rand vuonna 1841. 17 Alexander Katlan. "The American Artist's Tools and Materials for On-site Oil Sketching", Journal of American Institute for Conservation, vol. 38,

nro. 1 (1999): 21-32, luettu 19.6.2019. http://cool. conservation-us.org/coolaic/jaic/articles/jaic38-01003.html.

18 Behrend green -niminen seos sisältää hydratoitua kromioksidivihreää ja strontium- tai kadmiumkeltaista. Nicholas Eastaugh, Valentine Walsh, Tracey Chaplin ja Ruth Siddall, Pigment Compendium. A Dictionary of Historical Pigments. (Oxford: Elsevier ButterworthHeinemann, 2004), 42. Tutkimusaineistossa tätä väriaineyhdistelmää ko. kauppanimellä on myynyt Fitz Behrendt Farbe.

19 Green cinnabar tai hrome green on seos kromi- tai strontiumkeltaisesta ja preussinsinisestä. Herman Kühn ja Mary Curran, "Chrome Yellow and Other Chromate Pigments", teoksessa Artist's Pigments. A Handbook of Their History and Characteristics. Volume 1, toimittanut Robert Feller, (Washington: National Gallery of Arts ja Lontoo: Archetype

Publications, 1986), 189. Tutkimusaineistossa on yks etiketitön väriainetuubi, joka sisältää preussinsinistä ja kromikeltaista väriainetta muodostaen vaalean vihreän maalin.

20 Permanent green -niminen seos sisältää

hydratoitua kromioksidivihreää ja sinkkikeltaista sekä bariumsulfaattia. Eastaugh, Walsh, Chaplin ja Siddall, Pigment Compendium. A Dictionary of Historical Pigment, 302. Tutkimusaineistossa tätä väriaineseosta kyseisellä kauppanimellä ovat myyneet Beckmann's Syntons-Farben ja Weimarfarbe.

21 Eastaugh, Walsh, Chaplin ja Siddall, Pigment Compendium. A Dictionary of Historical Pigments, 10 22 Leslie Carlyle. The Artist's Assistant. Oil Painting Instruction Manuals and Handbooks in Britain 1800 1900 with Reference to Selected Eighteenth-century Sources. (Lontoo: Archetype Publications Ltd., 2001), 156.

\section{3 engl. non-destructive}

24 Tällaisia väriaineita ovat muun muassa kromija kupariyhdisteet, koboltinvihreä, ultramariini ja preussinsininen.

25 Mikroskopiatutkimuksia varten teoksesta otetaan näyte, joka sisältää muutamia väriainepartikkeleita. Näyte otetaan teoksesta stereomikroskoopin alla näytteenottoa varten kehitetyllä näytteenottoneulalla. Näyte asetetaan tutkimusmenetelmälle sovittuun standarditaitekertoimen omaavaan väliaineeseen objekti- ja peitinlasin väliin. Yleisimmin väliaineena käytetään termoplastista Cargille Meltmount 1.662 polymeeria. Näin valmistetut näytteet ovat hyvin aikaa kestäviä ja analyysimenetelmän voi sanoa olevan ainetta rikkomaton, koska näyte ei analyysiprosessin aikana vaurioidu.

26 Kahtaistaitteisessa materiaalissa valonsäde jakautuu kahdeksi säteeksi sen kulkiessa kiteen läpi. Tällaista materiaalia kutsutaan anisotrooppiseksi. Jos valonsäde kulkee jakautumattomana materiaalin läpi, suunnasta riippumatta, kutsutaan sitä isotrooppiseks Pleokroismi on kahteistaitteisten värillisten

materiaalien optinen ominaisuus, jonka seurauksena sen väri muuttuu sitä tarkasteltaessa eri suunnista. 27 Kansallisgalleria, inventaarionumero A II 1142.
28 Kansallisgalleria, inventaarionumero A I 857. 29 Kansallisgalleria, inventaarionumero A II 1479. 30 Kansallisgalleria, inventaarionumero A II 1050. 31 Kansallisgalleria, inventaarionumero A I 640. 32 Tutkimustulosten tilastollinen osuus raportoidaan vain niiden väriaineiden osalta, joiden tunnistus on mahdollista ilman näytteenottoa.

33 Tunnetaan myös nimellä thenardinsininen. Valmistusmenetelmä kehitettiin vuonna 1803-04, ja se on otettu käyttöön taiteilijaväriaineena melko pian kehittämisen jälkeen. Eastaugh, Walsh, Chaplin ja Siddall, Pigment Compendium. A Dictionary of Historical Pigments, 113; Ashok, Roy, "Cobalt Blue", teoksessa Artist's Pigments. A Handbook of Their History and Characteristics. Volume 4, toimittanut Barbara Berrie, (Washington: National Gallery of Arts ja Lontoo: Archetype Publications, 2007), 152-153. 34 Nicholas Eastaugh, Valentine Walsh, Tracey Chaplin ja Ruth Siddall, Pigment Compendium. Optical Microscopy of Historical Pigments, 575 35 Muriel Geldof ja Lise Steyn, "Van Gogh's Cobalt Blue", teoksessa Van Gogh's Studio Practice, toimittaneet Marija Vellekoop, Muriel Geldof, Ella Hendriks, Leo Jansen ja Alberto de Tagle (New Haven ja Lontoo: Van Gogh Museum ja Mercatorfonds, Yale University Press, 2013), 259-260. Epäpuhtauksista on valmistusprosesseja kehitettäessä pyritty eroon, koska erityisesti nikkeli muuttaa väriaineen sävyä violetimpaan suuntaan.

36 Kutsutaan myös reliefiksi.

37 Winchell, The Microscopic Characters of Artificial Inorganic Solid Substances or Artificial Minerals, 195; Eastaugh, Walsh, Chaplin ja Siddall, Pigment Compendium. Optical Microscopy of Historical Pigments, 35; Roy,"Cobalt Blue", 160

38 Tunnetaan myös nimellä kölninsininen (saks. Coelinblau). Kaupallistettu Britanniassa 1860-luvulla Carlyle, The Artist's Assistant. Oil Painting

Instruction Manuals and Handbooks in Britain

1800-1900 With Reference to Selected Eighteenthcentury Sources, 472; Seppo Hornytzkyj," Sinisten

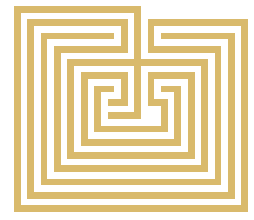


perinteisten taiteilijaväriaineiden tunnistaminen polarisaatiomikroskoopilla". (Helsinki: Helsingin yliopisto, Geotieteiden ja maantieteen laitos, 2017), 65.

39 Koska kyseessä on analyysimenetelmä, joka vaatii näytteenoton, eikä kaikista teoksista voitu ottaa näytettä, ei preussinsinisen läsnäoloa huomattavasti useammassa teoksessa voi sulkea pois.

40 Serlachius-museot, Sammon ryöstö, osaluonnos.

Inventaarionumero 98

41 Kaupalliseen taiteilijaväriainekäyttöön tullut 1710-luvulla. Barbara Berrie,"Prussian blue", teoksessa Artist's Pigments. A Handbook of Their History and Characteristics. Volume 3, toimittanut Elisabeth West Fitzhugh (Washington: National Gallery of Art. New York ja Oxford: Oxford University Press, 1994), 193

42 Eastaugh, Walsh, Chaplin ja Siddall, Pigment Compendium. Optical Microscopy of Historical Pigments, 115

43 Kirjallisuudessa raportoidaan myös, että toisinaan preussinsininen muuttuu punertavaksi, harmaaksi tai pysyy sinisenä. Hornytzkyj," Sinisten perinteisten taiteilijaväriaineiden tunnistaminen polarisaatiomikroskoopilla", 93.

44 Etiketitön vihreää väriainetta sisältävä väriainetuubi. Gallen-Kallelan Museo,

inventaarionumero GKM-4399.

45 Jo Kirby ja David Saunders, "Fading and Colou Change of Prussian Blue: Methods of Manufacture and the Influence of Extenders", National Gallery Technical Bulletin vol. 25 (2004): 72-99, luettu 10.1.2018. https://www.nationalgallery.org.uk/upload pdf/kirby saunders2004.pdf.

46 Kansallisgalleria, inventaarionumero A I 912.

47 Kansallisgalleria, inventaarionumero A I 566.

48 Synteettistä ultramariinia ryhdyttiin valmistamaan taiteilijaväriainekäyttöön 1830-luvulla. Joyce Plesters,

"Ultramarine Blue, Natural and Artificial", teoksessa Artist's Pigments. A Handbook of Their History and Characteristics. Volume 2, toimittanut Ashok Roy
(Washington: National Gallery of Art. New York ja Oxford: Oxford University Press, 1993), 56.

49 Koska kyseessä on analyysimenetelmä, joka vaatii näytteenoton, eikä kaikista teoksista voitu ottaa näytettä, ei synteettisen ultramariinin läsnäoloa huomattavasti useammassa teoksessa voi sulkea pois.

50 Mitä varhaisemmasta väriaineesta on kyse, sitä suurempia ja kulmikkaampia partikkelit ovat. Myös partikkelikokojakauma voi olla laaja. Eastaugh

Walsh, Chaplin ja Siddall, Pigment Compendium. Optical Microscopy of Historical Pigments, 45. 51 Joyce Plesters,"Ultramarine Blue, Natural and Artificial", 55.

52 Tunnetaan myös nimellä vermilion. Synteettinen sinooperin valmistaminen tunnettiin lännessä jo Rooman valtakunnan aikaan. Eastaugh, Walsh, Chaplin ja Siddall, Pigment Compendium. A Dictionary of Historical Pigments, 105 53 Dr. Fr. Schoenfeld \& Co, Karmin-Zinnober. GallenKallelan Museo, inventaarionumero GKM-4399. 54 Gettens, Feller ja Chase, "Vermillion and Cinnabar, 163; Eastaugh, Walsh, Chaplin ja Siddall, Pigment Compendium. A Dictionary of Historical Pigments, 105.

55 Eastaugh, Walsh, Chaplin ja Siddall, Pigment Compendium. Optical Microscopy of Historical Pigments, 197.

56 Eastaugh, Walsh, Chaplin ja Siddall, Pigment Compendium. Optical Microscopy of Historical Pigments, 195.

57 Keltaiset kadmiumyhdisteet kaupallistettiin taiteilijaväriaineena 1840-luvulla. Inge Fiedler ja Michael Bayard, "Cadmium Yellows, Oranges and Reds", teoksessa Artists' Pigments. A Handbook of Their History and Characteristics. Volume 1, toimittanut Robert Feller, (Washington: National Gallery of Arts ja Lontoo: Archetype Publications, 1986), 67.

58 Kiderakenteeksi on ilmoitettu kuutiollinen ja heksagoninen, mutta myös amorfisia ja sferuli- rakenteita on tunnistettu. Fiedler ja Bayard, "Cadmium Yellows, Oranges and Reds", 81.

59 Fiedler ja Bayard, "Cadmium Yellows, Oranges and Reds", 65.

60 Fiedler ja Bayard, "Cadmium Yellows, Oranges and Reds", 75.

61 Gallen-Kallelan Museo, Ensilumi Ruovedellä,

1920. Inventaarionumero GKM-7378.

62 Winchell, The Microscopic Characters of Artificial Inorganic Solid Substances or Artificial Minerals, 158. 63 Fiedler ja Bayard, "Cadmium Yellows, Oranges and Reds", 82.

64 Leone Bronwyn, Aviva Burnstock, Chris Jones,

Peter Hallebeek, Jaap Boon ja Katrien Keune,

"The Deterioration of Cadmium Sulphide Yellow Artists' Pigments", ICOM-CC 14th triennial meeting, preprints, 803-813 (The Hague, 12.-16. 9. 2005). 65 Kühn ja Curran, "Chrome Yellow and Other Chromate Pigments", 189. Keltaisen lyijykromaatin käyttö taiteilijaväriaineena alkoi 1804-09.

66 Tunnetaan myös nimellä viridiaani. Patentti myönnettiin vuonna 1859 ja taiteilijaväriaineena se kaupallistettiin vuonna 1869. Eastaugh, Walsh, Chaplin ja Siddall, Pigment Compendium. A

Dictionary of Historical Pigments, 391.

67 Kühn ja Curran "Chrome Yellow and Other Chromate Pigments", 187. Strontiumkromaatti tuli käyttöön 1800-luvun jälkimmäisellä puoliskolla.

68 Näytteenotollisista syistä johtuen teoksista, joista kromi tunnistettiin, ei tutkittu mistä kromiyhdisteestä on kyse. Väriaine tunnistettiin yleisimmin

kromipitoiseksi väriksi ja tilastollisessa tarkastelussa päädyttiin raportoimaan tulos kokonaisuutena kromikeltainen tai -vihreä.

69 Kühn ja Curran "Chrome Yellow and Other Chromate Pigments, 194.

70 Kühn ja Curran, "Chrome Yellow and Other Chromate Pigments", 188

11 Kühn ja Curran, "Chrome Yellow and Other

Chromate Pigments", 190-191.

72 Kansallisgalleria, inventaarionumero A III 2616.

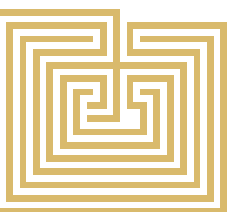


73 Kansallisgalleria, inventaarionumero A III 2174. 74 Hydratoidun kromioksidivihreän valmistus patentoitiin 1859, mutta ensimmäisen kerran sitä mainitaan valmistetun jo vuonna 1838. Richard Newman, "Chromium Oxide Greens. Chromium Oxide and Hydrated Chromium Oxide", teoksessa Artist's Pigments. A Handbook of Their History and Characteristics. Volume 3, toimittanut Elisabeth West Fitzhugh. (Washington: National Gallery of Art, New York ja Oxford: Oxford University Press, 1997), 275. 75 Newman,"Chromium Oxide Greens. Chromium Oxide and Hydrated Chromium Oxide", 283. 76 Tunnetaan myös nimellä rinmanninvihreä. Taiteilijaväriainekäyttöön se tuli 1700-luvun loppupuolella Eastaugh, Walsh, Chaplin ja Siddall, Pigment Compendium. A Dictionary of Historical Pigments, 323.

77 Koska tunnistus vaatii näytteenoton, eikä kaikista teoksista voitu ottaa näytettä, tarkka koboltinvihreää sisältävien teosten lukumäärä ei ole tiedossa.

78 Kansallisgalleria, inventaarionumero A III 2166. 79 Tunnetaan muun muassa myös nimellä Schweinfurtin vihreä, se otettiin taiteilijaväriainekäyttöön 1800-luvun alkupuolella Erityisen suosittua se oli 1800-1900-Iukujen taitteessa. Eastaugh, Walsh, Chaplin ja Siddall, Pigment Compendium. A Dictionary of Historical Pigment, 149.

80 Inge Fiedler ja Michael Bayard," Emerald Green and Scheele's Green", teoksessa Artist's Pigments. A Handbook of Their History and Characteristics.

Volume 3, ed. Elisabeth West Fitzhugh. (Washington: National Gallery of Art, New York ja Oxford: Oxford University Press, 1997), 219.

81 Kansallisgalleria, inventaarionumerot A I 513, A I 640 ja A II 765.

82 Serlachius-Museot, inventaarionumerot 1368 ja 235. Unelmien saari -teos on osa yksityiskokoelmaa. 83 Serlachius-Museot, inventaarionumerot 308, 311, 307, 309 ja 1121.

84 Gallen-Kallelan Museo, inventaarionumero GKM-
322.

85 Katrien Keune, Jaap J. Boon, R. Boitelle ja Y. Shimadzu. "Degradation of Emerald Green in Oil Paint and Its Contribution to the Rapid Change in Colour of the Descente des Vaches (1834-1835) painted by Théodore Rousseau". Studies in Conservation vol.58, no. 3 (2013): 199-210, luettu 20.11.2018, https://www.tandfonline.com/doi/ full/10.1179/2047058412Y.0000000063.

86 Katrien Keune, Jennifer Mass, Apruva Mehta, Jonathan Church ja Florian Meier. "Analytical Imaging Studies of the Migration of Degradated Orpiment, Realgar and Emerald Green pigments in historic paintings and related conservation issues". Heritage Science 4:10 (2016). DOI 10.1186/s-40494-0160078-1. Luettu 18.11.2018, https://link.springer.com/ article/10.1186/s40494-016-0078-1.

87 Toisinaan kuparipitoista, kalsinoutua verdigriitä on käytetty puupaneelin käsittelyssä tai kuivikkeena öljyn seassa. Sir Arthur Church, The Chemistry of Paints and Paintings (Lontoo: Seeley, Sevice \& Co., 1915), 30; Carlyle 2004, 50

88 Kansallisgalleria, inventaarionumero A II 1133. 89 Kansallisgalleria, inventaarionumero A II 1061A

90 Kansallisgalleria, inventaarionumero A I 562.

91 Kansallisgalleria, inventaarionumero A III 2619. 92 Kansallisgalleria, inventaarionumero A III 2224 93 Kansallisgalleria, inventaarionumero A III 2620. 94 Kansallisgalleria, inventaarionumero A III 2167. 95 Kansallisgalleria, inventaarionumero A III 2168. 96 Helmut Schweppe ja John Winter, "Madder and Alizarin", teoksessa Artist's Pigments. A Handbook of Their History and Characteristics. Volume 3, ed. Elisabeth West Fitzhugh. (Washington: National

Gallery of Art, New York ja Oxford: Oxford University Press, 1997), 124

97 Muriel Geldof, Matthijs de Keijzer, Maarten van Bommel, Kathrin Pilz, Johanna Salvant, Henk van Keulen ja Luc Megens, "Van Gogh's Geranium Lake", teoksessa Van Gogh's Studio Practice, toimittaneet Marija Vellekoop, Muriel Geldof, Ella Hendriks, Leo
Jansen ja Alberto de Tagle (New Haven ja Lontoo: Van Gogh Museum ja Mercatorfonds, Yale University Press, 2013), 276.

98 Geldof, de Keijzer, van Bommel, Pilz, Salvant, van Keulen ja Megens, "Van Gogh's Geranium Lake", 271.

99 Aviva Burnstock, Ibby Lenfear, Klaas Jan van den Berg, Leslie Carlyle, Mark Clarke, Ella Hendriks ja Jo Kirby, " Comparison of the Fading and Surface Deterioration of Red Lake Pigments in Six Paintings by Vincent van Gogh with artificially Aged Paint Reconstructions", ICOM-CC 14th triennial meeting preprints, 459-466. (The Hague, 12.-16. 9. 2005). 100 Eastaugh, Walsh, Chaplin ja Siddall, Pigment Compendium. A Dictionary of Historical Pigments, 377.

101 Wilh. Becker, Kromoxidgrönt. Inventaarionumero GKM-898.

102 Kansallisgalleria, inventaarionumero A II 1254:56. Maavihreää voi esiintyä huomattavasti useammassa eoksessa, koska sen tunnistaminen vaati näytteenoton. Yhden Schminken väriainetuubin nimi on Grüne verde. Se ei kuitenkaan sisällä maavihreää vaan ruskeaa rautaoksidiväriä.

103 Teokset: Kansallisgalleria, Bohême, Carl Adam Dörnberger, inventaarionumero A II 1061a; Serlachius-museot, Mies saunan ulkopenkillä, inventaarionumero 810. Väriainetuubit: $\mathrm{H}$. Schmincke, zinnoberrot, inventaarionumero GKM-898; Sadolins Faerven, cinnoberrodt, inventaarionumero GKM4399; Pelikanfarbe, zinnober imit., inventaarionumero GKM-898. On huomioitava, että teoksissa on aina lyijyvalkoista, joten lyijypunaisen tunnistaminen tapahtuu polarisaatiomikroskopian avulla. Koska lyijypunaisen tunnistaminen vaatii näytteenoton, eikä kaikista teoksista voitu ottaa näytettä, ei ole tiedossa, kuinka usein Gallen-Kallela sitä käytti.

104 Kansallisgalleria, Luminen pihamaa,

inventaarionumero A III 2615; Kansallisgalleria,

Kuusia karjapihassa, joulukuusia takapihassa, inventaarionumero A II 1248

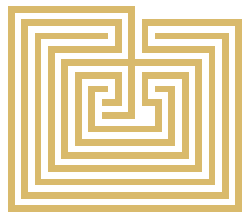


105 Teos: Kansallisgalleria, Akaasiapuu aavikolla, inventaarionumero A III 2172. Väriainetuubi:

J.Blockx Fils á vieux-dieu, vert compose no. 2 ,

invantaarionumero GKM-4399. Koboltinkeltaisen

tunnistaminen vihreistä seoksista vaatii näytteenoton

polarisaatiomikroskopiatutkimuksia varten. Koska

jokaisesta teoksesta ei voitu ottaa näytettä,

koboltinkeltainen saattaa esiintyä useassakin Gallen-

Kallelan teoksessa. Se esiintyy seoksena yhdessä

hydratoidun kromioksidivihreän kanssa.

106 Cornman, "Cobalt Yellow (Aureolin)", 39.

107 Teokset: Serlachius-museot, Mrs Margaret Lippo Hecht ja tytär Margareta, kaksoismuotokuvaluonnos,

inventaarionumero 618; Gallen-Kallelan Museo,

Mrs Hecht, muotokuvaluonnos, inventaarionumero

GKM-313; Kansallisgalleria, Intiaani ratsain,

inventaarionumero A III 2159 .

\section{Analyysilaitteiston tekniset tiedot}

Bruker S1 TITAN -röntgenfluoresenssispektrometri, jonka mittausalue on noin $3 \mathrm{~mm}$ suuruinen. Rhodium anodi; kaksi mittaustapaa; jännite $40 \mathrm{kV}$, virta $8 \mu \mathrm{A}$ Ti/Al-suodin ja mittausaika 30s, ja $15 \mathrm{kV}, 17 \mu \mathrm{A}$, ei suodinta ja mittausaika $30 \mathrm{~s}$.

Olympus $\mathrm{BH}-2$ ja Leica DMRX

polarisaatiotutkimusmikroskoopit. Leica $\mathrm{MZ}$

12-stereomikroksooppi. Mikroskooppikuvat otettiin

Nikon Coolpix 4500-digitaalikameralla.
FM Hanne Tikkala on tohtorikoulutettava Jyväskylän yliopistossa ja osa-aikainen tutkija Kansallisgallerian materiaalitutkimuslaboratoriossa. Tämä artikkeli on ensimmäinen hänen suomalaisten taiteilijoiden väriainepaletteja käsittelevän väitöskirjansa artikkeleista. Tutkimustyötä on tehty Suomen Kulttuurirahaston ja Suomen Museoalanammattiliiton apurahojen turvin.

FM Seppo Hornytzkyj toimii erikoistutkijana Kansallisgallerian materiaalitutkimuslaboratoriossa. Tässä tutkimuksessa hän toimii tutkimustyön ohjaajana.

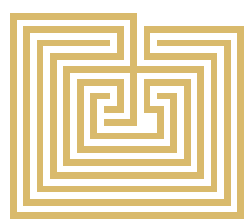


Taulukko 1

\begin{tabular}{|c|c|}
\hline omistaja & teoksen nimi (inv. no.) \\
\hline Kansallisgalleria & Malliharjoitelma (A IV 4220) \\
\hline Gallen-Kallela Museo & Kuutamomaisema (GKM-322) \\
\hline Gallen-Kallela Museo & Mucius Scaevola, tuomio (GKM-324) \\
\hline Gallen-Kallela Museo & Sisäkuva Jaatsista (GKM-282) \\
\hline Gallen-Kallela Museo & Leikkuusalissa, ruumiinavaus (GKM-729) \\
\hline Gallen-Kallela Museo & Vanki (GKM-340) \\
\hline Gallen-Kallela Museo & Vangin kuljetus (GKM-271) \\
\hline Gallen-Kallela Museo & Kaartin puutarhassa (GKM-281) \\
\hline Yksityiskokoelma & Helsingin rannikolla, Flisholmen \\
\hline Kansallisgalleria & Särkkä, Viaporin patterista (A III 2613) \\
\hline Gallen-Kallela Museo & Talvimaisema Jaatsissa (GKM-335) \\
\hline Gallen-Kallela Museo & Liuskasaari Helsingin lähellä, Flisholmen (GKM-270) \\
\hline Gallen-Kallela Museo & Mäntymäki (GKM-341) \\
\hline Gallen-Kallela Museo & Ratsumiehiä talon pihalla (GKM-337) \\
\hline Kansallisgalleria & Luminen pihamaa (A III 2615) \\
\hline Serlachius Museot & Kalliomaisema (78) \\
\hline Serlachius Museot & Veneitä rannalla (79) \\
\hline Kansallisgalleria & Kevättalvi, lumen sulaminen(A III 2609) \\
\hline Kansallisgalleria & Näköala Fredrikinkadulta (A III 2149) \\
\hline Yksityiskokoelma & Uivia tyttöjä \\
\hline Gallen-Kallela Museo & Näköala Jaatsista yli Tyrvään uuden kirkon (GKM-273) \\
\hline Gallen-Kallela Museo & Metsänsisusta (GKM-327) \\
\hline Gallen-Kallela Museo & Pikkuharjoitelmia (GKM-325) \\
\hline Kansallisgalleria & Sadepilviä järvimaiseman yllä (A II 1140) \\
\hline Serlachius Museot & Sisäkuva Keuruun pappilasta (400) \\
\hline Serlachius Museot & Elämä ja kuolema (1368) \\
\hline Serlachius Museot & Takapiha (75) \\
\hline Serlachius Museot & Luhtikuja, Hoskarin talo Keuruulla (399) \\
\hline Gallen-Kallela Museo & Uno Gallén muotokuva (GKM-339) \\
\hline Yksityiskokoelma & Talonpoikaistyttö \\
\hline Kansallisgalleria & Pariisilainen takapiha, Ateljerin ikkunasta (A III 2616) \\
\hline Gallen-Kallela Museo & Varhainen aamu venerannassa (GKM-274) \\
\hline Kansallisgalleria & Kylämaisema lampaineen (A II 1133) \\
\hline Kansallisgalleria & Auringonpaisteessa (A II 1134) \\
\hline Kansallisgalleria & Mädäntynyt kuha (A III 1136) \\
\hline Kansallisgalleria & Veneranta (A II 1135) \\
\hline Kansallisgalleria & Maalaiseukko (A III 2617) \\
\hline Kansallisgalleria & Sumumaisema, sumua niityllä (A III 2614) \\
\hline Gallen-Kallela Museo & Ruusan punkka, asetelma (GKM-333) \\
\hline \begin{tabular}{|l} 
Kansallisgalleria \\
\end{tabular} & \begin{tabular}{|l|} 
Kaislikko (A II 1137) \\
\end{tabular} \\
\hline Kansallisgalleria & Poika ja Varis (A II 912) \\
\hline Kansallisgalleria & Turun tuomiokirkko (A III 2089) \\
\hline Gallen-Kallela Museo & Harjoitelmia (GKM-275) \\
\hline
\end{tabular}
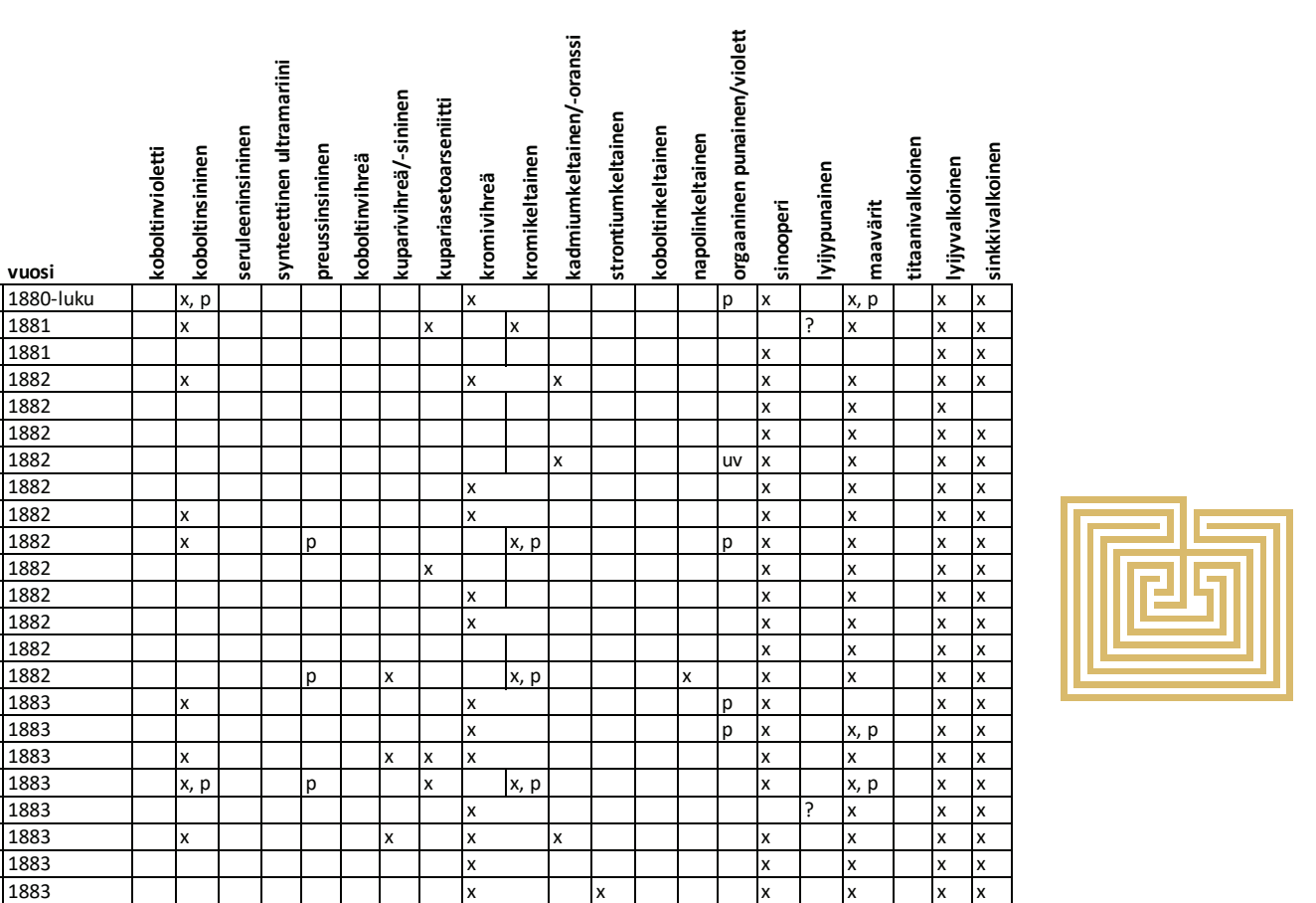

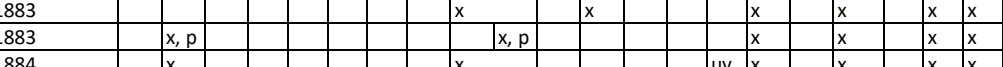

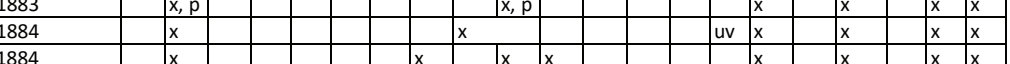

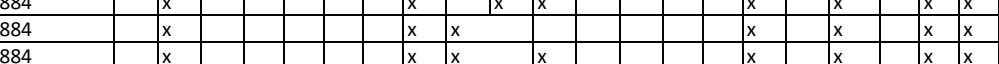
\begin{tabular}{l|l|l|l|l|l|l|l|l|l|l|l|l|l|l|l|l|}
\hline 1884 & $\mathrm{x}$ & & & & & & $\mathrm{x}$ & $\mathrm{x}$ & $\mathrm{x}$ & & & & $\mathrm{x}$ & $\mathrm{x}$ & $\mathrm{x}$ & $\mathrm{x}$ \\
\hline 1884 & & & & & & & $\mathrm{x}$ & & & & & & $\mathrm{x}$ & $\mathrm{x}$ & $\mathrm{x}$ & $\mathrm{x}$ \\
\hline
\end{tabular}

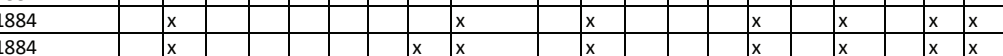

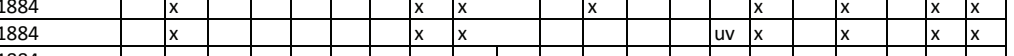
\begin{tabular}{|l|l|l|l|l|l|l|l|l|l|l|l|l|l|l|l|l|l|}
\hline 1884 & $x, p$ & $p$ & $x$ & & & $x, p$ & $x, p$ & & & & $p$ & $x, p$ & $x$ & & $x$ & $x$ \\
\hline 1884 & $x, p$ & & & $x$ & & $x, p$ & $x$ \\
\hline
\end{tabular} \begin{tabular}{l|l|l|l|l|l|l|l|l|l|l|l|l|l|l|l|}
\hline 1884 & $\mathrm{x}, \mathrm{p}$ & & & & & $\mathrm{x}$ & $\mathrm{x}$ & $\mathrm{x}$ & & & & $\mathrm{x}$ & $\mathrm{x}$ & $\mathrm{x}$ & $\mathrm{x}$ \\
\hline 1884 & $\mathrm{x}$ & $\mathrm{p}$ & $\mathrm{x}$ & $\mathrm{x}$ & $\mathrm{x}$ & & & & $\mathrm{p}$ & $\mathrm{x}$ & $\mathrm{x}, \mathrm{p}$ & $\mathrm{x}$ & $\mathrm{x}$ \\
\hline
\end{tabular}

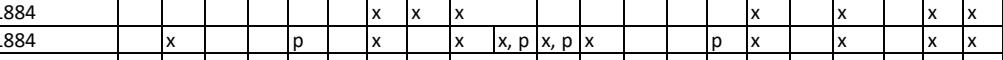

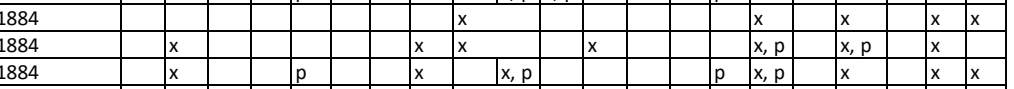

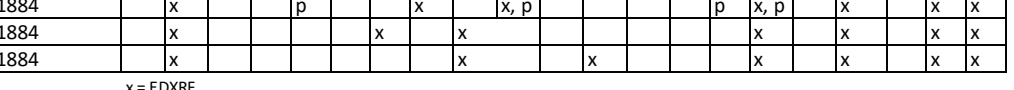
$x=$ EDXKF
$p=$ PLM

$u v=$ UV fluoresenssi 
Taulukko 1 jatk.

\begin{tabular}{|c|c|}
\hline omistaja & teoksen nimi (inv. no.) \\
\hline Serlachius Museot & Akka ja vasikka (83) \\
\hline Kansallisgalleria & Lehmä ja poika (A II 1144) \\
\hline Kansallisgalleria & Kekki-renki, lepäämässäa aterian jälkeen (A III 2153) \\
\hline Kansallisgalleria & Malliharjoitelma, ensimmäinen mallini(?) (A III 2606) \\
\hline Gallen-Kallela Museo & Piispa Henrik kastaa suomalaisia (GKM-750) \\
\hline Kansallisgalleria & Muikunpaistaja (A III 1854) \\
\hline Serlachius Museot & Metsässä, neiti Thysell (294) \\
\hline Serlachius Museot & Aihe Pariisilaisesta kahvilasta (295) \\
\hline Yksityiskokoelma & Maisema Sä̈̈ksmäen Rapolasta \\
\hline Kansallisgalleria & Huutolaispoika (A III 2612) \\
\hline Kansallisgalleria & Eksynyt (A III 2224) \\
\hline Kansallisgalleria & Käsikivillä jauhaja (A IV 2852) \\
\hline Kansallisgalleria & Karjapiha (A II 1143) \\
\hline Kansallisgalleria & |IItamaisema eläintarhasta (A III 1725) \\
\hline Kansallisgalleria & Tohtori Herman Frithiof Antellin muotokuva (A I 566) \\
\hline Serlachius Museot & Talonpoikaiselämää (1353) \\
\hline Kansallisgalleria & Viittatie jäällä (A || 1141) \\
\hline Kansallisgalleria & Talvimaisema (A II 1138) \\
\hline Kansallisgalleria & Kuusia karjapihassa, joulukuusia takapihassa (A II 1248) \\
\hline Kansallisgalleria & Ensi opetus (A II 857) \\
\hline Yksityiskokoelma & Taiteilijan morsiamen muotokuva, mustapukuinen Mary \\
\hline Gallen-Kallela Museo & Ekolan ukko tyttärineen (GKM-331a) \\
\hline Kansallisgalleria & Liedenääressä, tuvan sisusta (A II 1142) \\
\hline Gallen-Kallela Museo & Luonnos Mary Slöörin muotokuvaa varten (GKM-343) \\
\hline Gallen-Kallela Museo & Kylpylaitoksen rantaa Kaivopuistossa (GKM-278) \\
\hline Serlachius Museot & Demasquée, harjoitelma (226) \\
\hline Kansallisgalleria & Demasquée (A I 562) \\
\hline Kansallisgalleria & Sommitteluharjoitelma, roomalainen triumfikulkue (A III 2610) \\
\hline Kansallisgalleria & Bohême, Carl Adam Dörnberger (A II 1061 A) \\
\hline Kansallisgalleria & Alaston miesmalli (A III 2611) \\
\hline Kansallisgalleria & Kreivitär Berthe de Vallombreuse (A IV 4136) \\
\hline Gallen-Kallela Museo & Abraham ja lisak (GKM-277) \\
\hline Gallen-Kallela Museo & Nero Rooman palossa (GKM-279) \\
\hline Serlachius Museot & Maisema Ekolasta, Ekolan torpan maisema (621) \\
\hline Serlachius Museot & Mies saunan ulkopenkillä (810) \\
\hline Serlachius Museot & Kirkkotyttö (1147) \\
\hline Kansallisgalleria & Karhunputki (A III 2619) \\
\hline Kansallisgalleria & Valoa pilvien välistä (A II 1139) \\
\hline Kansallisgalleria & Saunassa (A II 1479) \\
\hline Kansallisgalleria & Syysmaisema, ensi lumi (A III 1888) \\
\hline Yksityiskokoelma & Tuvansisusta, Akonlahti \\
\hline Serlachius Museot & Tenhotar (235) \\
\hline Kansallisgalleria & IItarauha (A IV 3432) \\
\hline
\end{tabular}

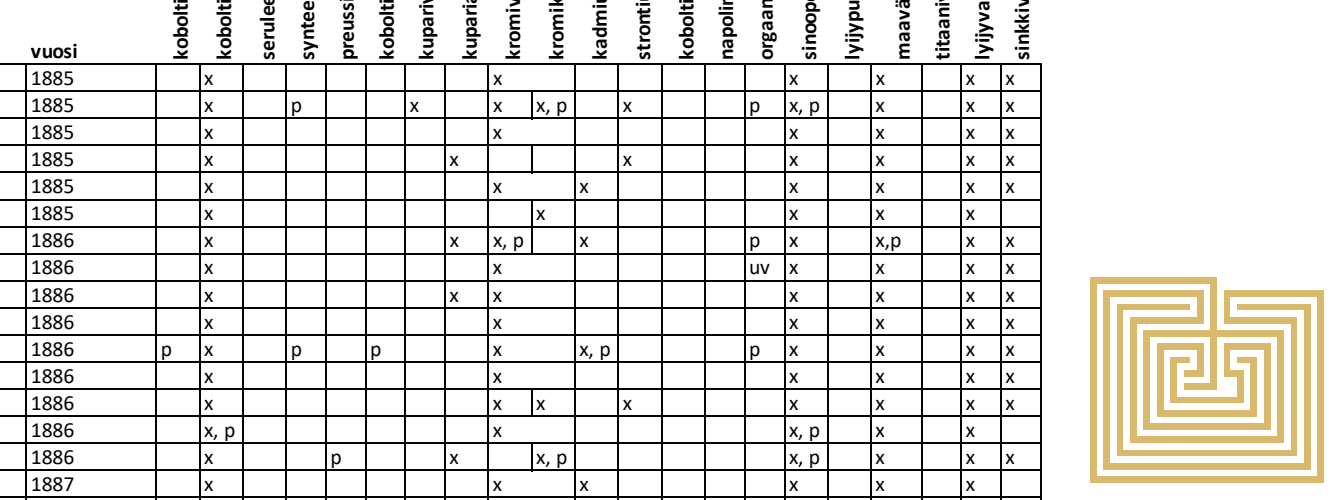


Taulukko 1 jatk.

\begin{tabular}{|c|c|}
\hline omistaja & teoksen nimi (inv. no.) \\
\hline Yksityiskokoelma & Talvimaisema, Malmilla \\
\hline Kansallisgalleria & Karjalainen nainen (A II 1254:56) \\
\hline Yksityiskokoelma & Sumuaamu Malmilla \\
\hline Yksityiskokoelma & |ltarusko Visuvedellä \\
\hline Gallen-Kallela Museo & Höyrylaivoja, jäänmurtajia (GKM-290) \\
\hline Serlachius Museot & Ekolan perhe (369) \\
\hline Yksityiskokoelma & Kitkajärvi, maisema Kuolajärveltä \\
\hline Kansallisgalleria & Taiteilijan vaimon muotokuva, Mary Gallen kalliomaisemassa (A III 1853) \\
\hline Kansallisgalleria & Sammon taonta (A I 513) \\
\hline Yksityiskokoelma & Kesäyö Vehmersalmella \\
\hline Gallen-Kallela Museo & | Lasimaalausluonnos "Talonpojan pytty ja kuninkaan kruunu" (GKM-3462) \\
\hline Kansallisgalleria & Saksalaisen näyttelijä Rudolf Rittnerin muotokuva (A II 1050) \\
\hline Serlachius Museot & Ukkospilviä taivaanrannalla (312) \\
\hline Kansallisgalleria & Tytön pää, Anna Slöör (A I 619) \\
\hline Yksityiskokoelma & Unelmien saari \\
\hline Kansallisgalleria & Lemminkäisen äiti (A I 640) \\
\hline Yksityiskokoelma & Greta Ahlmanin muotokuva, luonnos \\
\hline Kansallisgalleria & Prof E.R. Neoviuksen muotokuva (A IV 2773) \\
\hline Gallen-Kallela Museo & Greta Ahlmanin muotokuva \\
\hline Yksityiskokoelma & Mänty \\
\hline Kansallisgalleria & Kullervon kirous (A II 765) \\
\hline Yksityiskokoelma & IItarusko Ruovedellä \\
\hline Kansallisgalleria & Lemminkäinen (A-1992-230) \\
\hline Kansallisgalleria & IItamaisema (A III 2607) \\
\hline Kansallisgalleria & Talvimaisema, talvimaisema Ruovedeltä (A IV 3653) \\
\hline Kansallisgalleria & Kalelan kuisti (A III 2620) \\
\hline Serlachius Museot & Alaston, istuva naismalli (72) \\
\hline Yksityiskokoelma & Jäälauttoja rannalla, luminen ranta \\
\hline Kansallisgalleria & Järvimaisema (A-2010-173) \\
\hline Serlachius Museot & Hävitys, harjoitelma Sigrid Juséliuksen mausoleumin freskoon (308) \\
\hline Serlachius Museot & Kuokkamies; kevät, harjoitelma Sigrid Juséliuksen mausoleumin freskoon (311) \\
\hline Serlachius Museot & Epätoivo, harjoitelma Sigrid Juséliuksen mausoleumin freskoon (307) \\
\hline Gallen-Kallela Museo & Gobeliini-aihe, Poseidon aihe (GKM-297) \\
\hline Yksityiskokoelma & Johtajatar Hanna Granströmin muotokuva \\
\hline Serlachius Museot & Syksy, harjoitelma Sigrid Juséliuksen mausoleumin freskoon (309) \\
\hline Serlachius Museot & Kevät, harjoitelma Sigrid Juséliuksen mausoleumin freskoon (1121) \\
\hline Yksityiskokoelma & Sumuinen maisema \\
\hline Kansallisgalleria & Mustahuivinen nainen (A-2007-126) \\
\hline Serlachius Museot & Kaatunut honka (77) \\
\hline Yksityiskokoelma & Syksyisen metsän eläimet \\
\hline Gallen-Kallela Museo & Lintulan ranta Keiteleellä, kesäilta (GKM-7364) \\
\hline
\end{tabular}

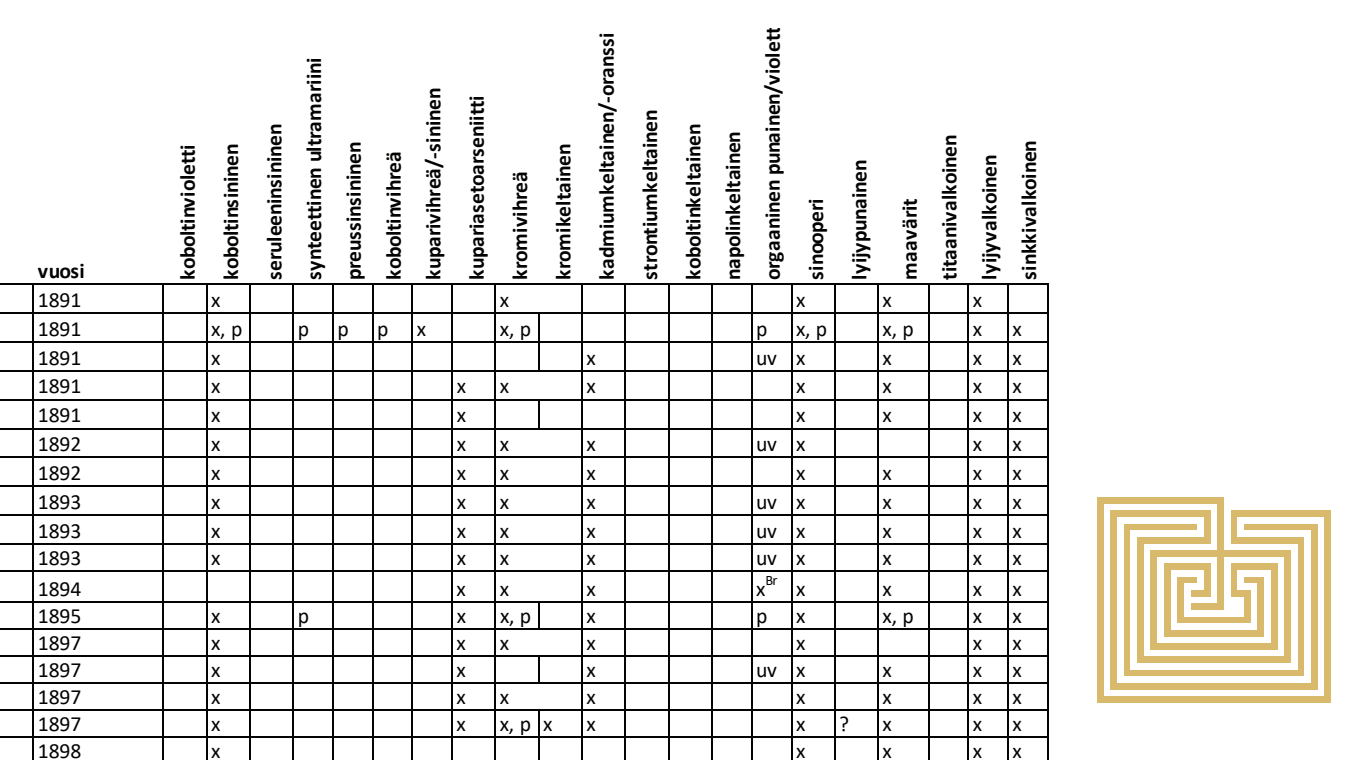

llela Museo

Linksyisen metsan elaimet
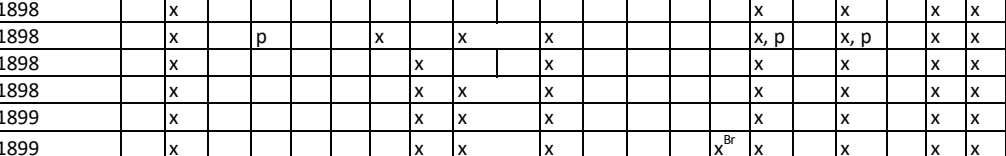

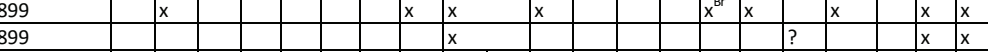

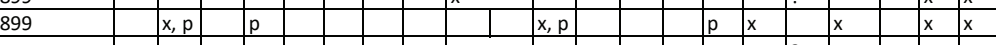

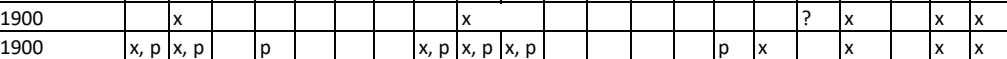

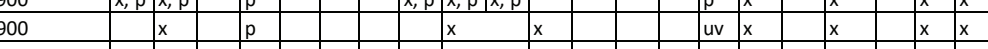
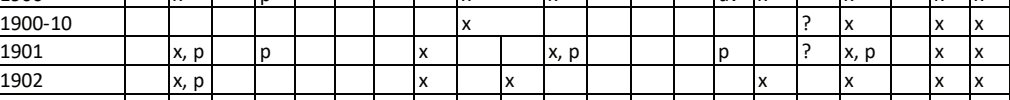

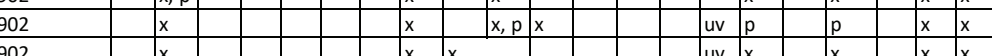
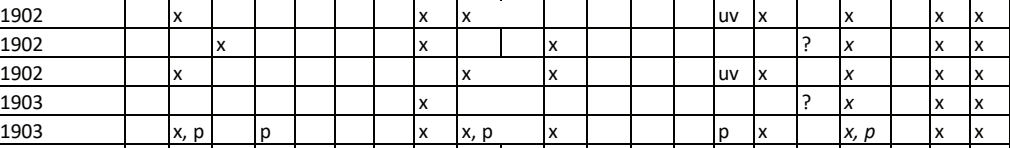

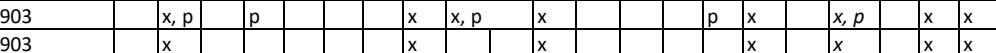

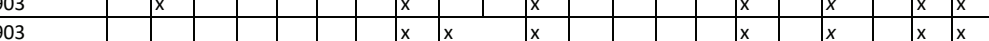

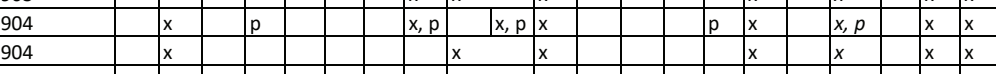
1904 
Taulukko 1 jatk.

\begin{tabular}{|c|c|}
\hline omistaja & teoksen nimi (inv. no.) \\
\hline Yksityiskokoelma & Metsäkivikko \\
\hline Yksityiskokoelma & Juurakko rantatörmässä \\
\hline Yksityiskokoelma & Juurakko hiekassa \\
\hline Yksityiskokoelma & Muotokuvaharjoitelma Mary Gallen-Kallela Lintulassa "Mary Gallen Lintulan rannassa" \\
\hline Yksityiskokoelma & Maisema Monte Carlosta \\
\hline Serlachius Museot & IIves-Matti (320) \\
\hline Serlachius Museot & Sammon ryöstö, osaluonnos (98) \\
\hline Gallen-Kallela Museo & Lumpeita (GKM-312) \\
\hline Yksityiskokoelma & Jääkarhu \\
\hline Gallen-Kallela Museo & Adolf Paulin muotokuva (GKM-300) \\
\hline Gallen-Kallela Museo & Raumankatu (GKM-3472) \\
\hline Gallen-Kallela Museo & Punalippu (GKM-7365) \\
\hline Yksityiskokoelma & Piha Raumalla \\
\hline Yksityiskokoelma & Rauman kirkko \\
\hline Yksityiskokoelma & Rauman kirkko ja joki \\
\hline Kansallisgalleria & Sammon ryöstö (A-1994-192) \\
\hline Kansallisgalleria & Talvimaisema (A III 2150) \\
\hline Gallen-Kallela Museo & Ahvenia (GKM-296) \\
\hline Yksityiskokoelma & Murtunut honka \\
\hline Gallen-Kallela Museo & Tyttö takan ääressä (GKM-302) \\
\hline Gallen-Kallela Museo & Peltopyyn jäljet (GKM-7368) \\
\hline Yksityiskokoelma & Haljennut kallio \\
\hline Kansallisgalleria & Rakennuksella (A IV 3655) \\
\hline Kansallisgalleria & Maxim Gorkin muotokuva (A III 2223) \\
\hline Gallen-Kallela Museo & Yksinäinen honka (GKM-7367) \\
\hline \begin{tabular}{|l|l} 
Yksityiskokoelma \\
\end{tabular} & Robert Kajanuksen muotokuvaharjoitelma Purren valitukseen \\
\hline Kansallisgalleria & Päivänpaisteisia hankia (A II 834) \\
\hline Gallen-Kallela Museo & Kahvilakuva Budapestistä (M591) \\
\hline Yksityiskokoelma & Lemminkäinen ja neidot \\
\hline Gallen-Kallela Museo & Kuninkaanlinna Budapestissä (M599) \\
\hline Gallen-Kallela Museo & \begin{tabular}{|l} 
Ravintolakuva Budapestistä (M710) \\
\end{tabular} \\
\hline \begin{tabular}{|l|} 
Gallen-Kallela Museo \\
\end{tabular} & $\begin{array}{l}\text { Professori Zilagyi, Budapest (M594) } \\
\end{array}$ \\
\hline Gallen-Kallela Museo & Tonavan sillan veistos (M595) \\
\hline Gallen-Kallela Museo & Katukuva Budapestistä (M597) \\
\hline Gallen-Kallela Museo & Kaksi herraa keskustelemassa Pariisin [Budapest] kadulla (M593) \\
\hline Yksityiskokoelma & Mary kuumalla lähteellä \\
\hline Gallen-Kallela Museo & Jokinäkymä illalla (M596A) \\
\hline Gallen-Kallela Museo & Jalopeura sillanpäässä kuutamossa (M596) \\
\hline Yksityiskokoelma & Kullervo petokarjoineen \\
\hline Yksityiskokoelma & Ukamban aro palaa \\
\hline Gallen-Kallela Museo & Myrsky Ruovedellä (GKM-7369) \\
\hline
\end{tabular}

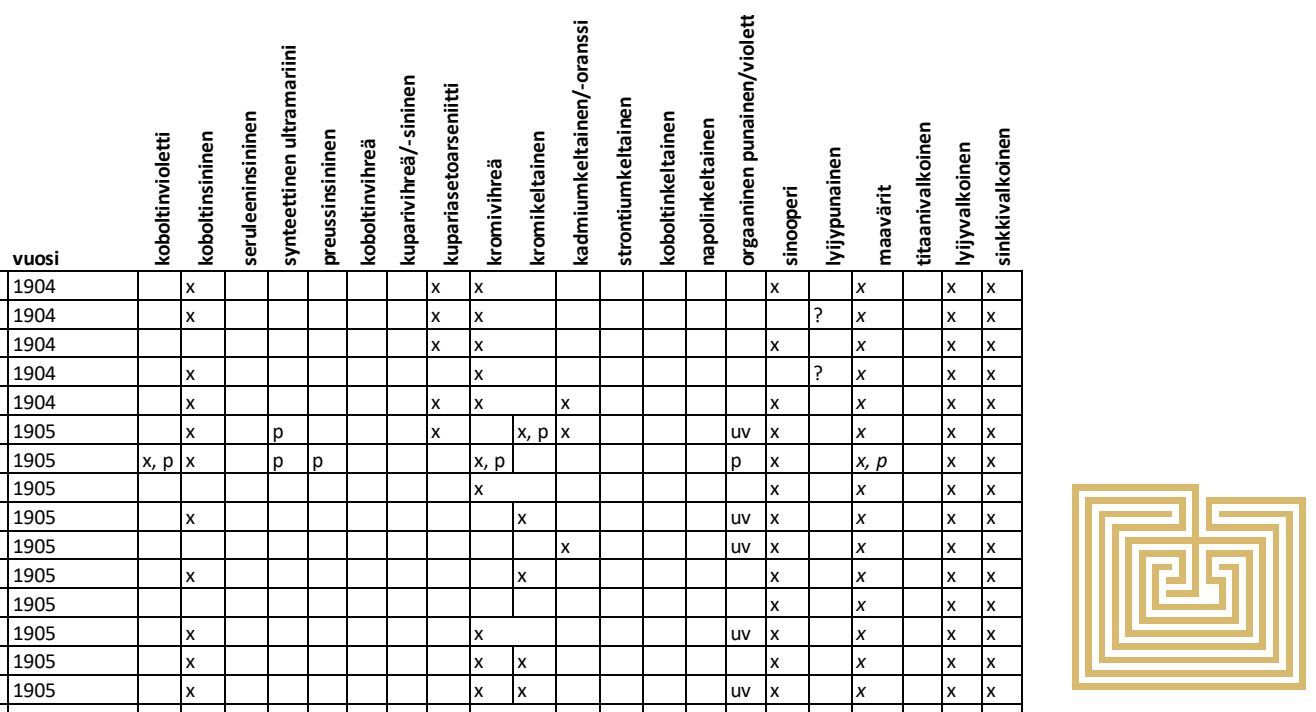

Myrsky Ruovedellä (GKM-7369) 
Taulukko 1 jatk.

\begin{tabular}{|c|c|}
\hline & teoksen nimi (inv. no.) \\
\hline Yksityiskokoelma & Southern Cross "Etelän risti Afrikan taivaalla" \\
\hline Yksityiskokoelma & Kuu \\
\hline Kansallisgalleria & Kikuju papyruskaislikossa (A III 2170) \\
\hline Kansallisgalleria & Seebroja, Seeproja Nairobin lähistöllä (A III 2164) \\
\hline Kansallisgalleria & Kikujumies (A III 2163) \\
\hline Kansallisgalleria & Lepäävä Afrikkalainen, lepäävä villi (A III 2173) \\
\hline Kansallisgalleria & Donya Sabuk -vuori (A III 2167) \\
\hline Kansallisgalleria & Aallottaria (A-1995-96) \\
\hline Gallen-Kallela Museo & Nandi-heimoa (GKM-3468) \\
\hline Kansallisgalleria & Akaasiapuu aavikolla (A III 2172) \\
\hline Kansallisgalleria & Tanssivia kikujusotilaita (A III 2171) \\
\hline Kansallisgalleria & | Auringonlasku aavikolla (A ||I 2176) \\
\hline Kansallisgalleria & Tana river (A III 2166) \\
\hline Gallen-Kallela Museo & Kamelin luuranko (GKM-316) \\
\hline Kansallisgalleria & Mount Kenya pilvissä (A III 2179) \\
\hline Gallen-Kallela Museo & Lepäävä villi, päivälepo \\
\hline \begin{tabular}{|l|l|} 
Yksityiskokoelma \\
\end{tabular} & Nature morte \\
\hline Gallen-Kallela Museo & Kilimandjaro-vuori (GKM-7372) \\
\hline Kansallisgalleria & Suezin kanavan rantaa (A III 2175) \\
\hline Kansallisgalleria & Nairobin ulkopuolelta (A III 2165) \\
\hline Kansallisgalleria & Jokilaakso (A III 2174) \\
\hline Kansallisgalleria & Väinämöisen venematka (A II 911) \\
\hline Yksityiskokoelma & Portti Nairobin kodissa \\
\hline Yksityiskokoelma & Kirsti ja banaaninlehti \\
\hline Yksityiskokoelma & "Aropuun juurakko", juurakoita \\
\hline Yksityiskokoelma & Kaadettu puhveli \\
\hline Gallen-Kallela Museo & Haukka (GKM-3467) \\
\hline Yksityiskokoelma & Kamelin luuranko arolla \\
\hline Yksityiskokoelma & Pyörremyrsky Nairobin tiellä;; "Upepa" \\
\hline Yksityiskokoelma & Kilimandjaro, ilta-auringossa Nairobin kodista nähtynä \\
\hline Yksityiskokoelma & Kikujumies \\
\hline Yksityiskokoelma & Arokulo \\
\hline Yksityiskokoelma & Portti Nairobin kodissa, Härkävaunut Nairobin tiellä \\
\hline Kansallisgalleria & Vaivasenpuu aavikolla (A III 2168) \\
\hline Yksityiskokoelma & Kikuijusotilas \\
\hline Yksityiskokoelma & Kenia-vuori \\
\hline Kansallisgalleria & Mount Kenya (A III 2177) \\
\hline Kansallisgalleria & Kukkiva korallipuu (A III 2178) \\
\hline Yksityiskokoelma & Taivaaseen kurottuva musta käsi \\
\hline Yksityiskokoelma & Villit ja magnolia "Kukkiva magnolia-puu Nairobin arolla" \\
\hline Gallen-Kallela Museo & Maisema Afrikasta "kaikkein kuumimmalta seudulta missä olimme" (M271) \\
\hline
\end{tabular}

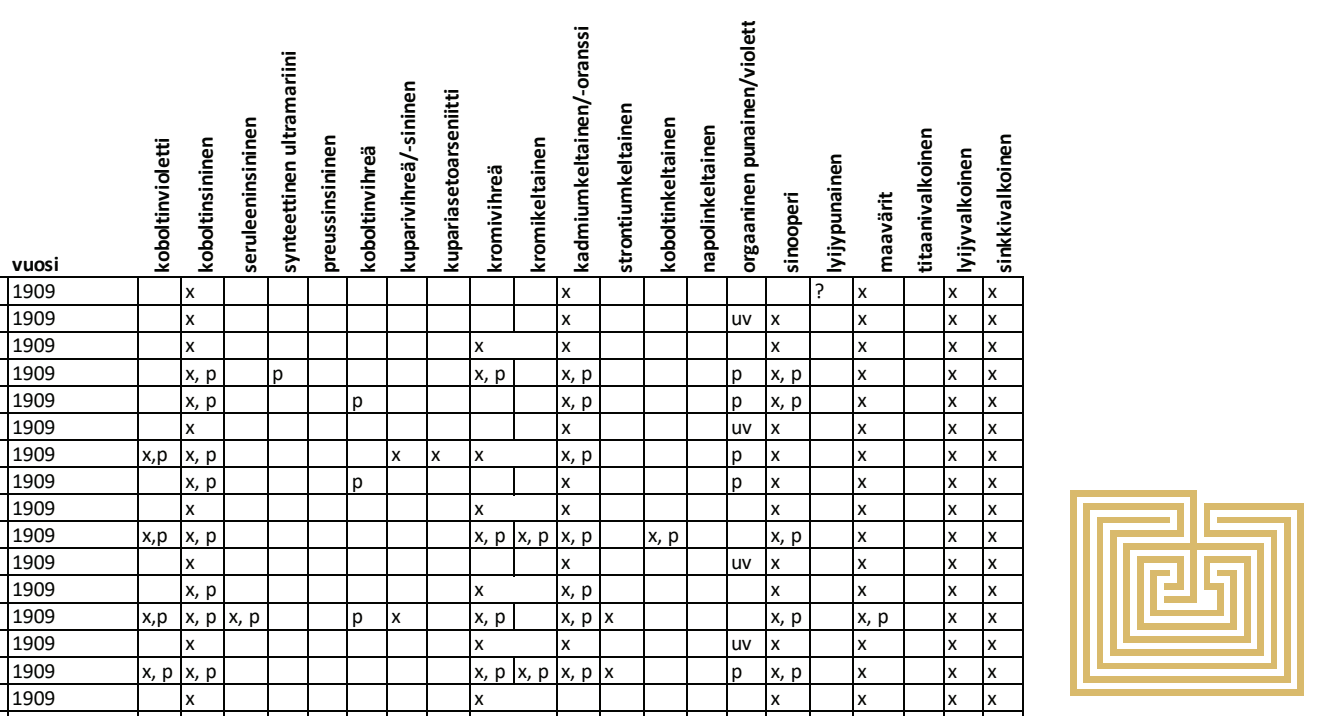


Taulukko 1 jatk.

\begin{tabular}{|c|c|}
\hline omistaja & teoksen nimi (inv. no.) \\
\hline Gallen-Kallela Museo & Aarniometsä, tuokiokuva Afrikasta (GKM-7374) \\
\hline Gallen-Kallela Museo & Leijona loikkaa (GKM-7373) \\
\hline Gallen-Kallela Museo & Punainen meri (GKM-7371) \\
\hline Yksityiskokoelma & Sfinksi ja hotelli \\
\hline Kansallisgalleria & Punaisen meren rantaa (A III 2169) \\
\hline Mannerheim Museo & Cheetah (73) \\
\hline Kansallisgalleria & Järvimaisema (A-2002-585) \\
\hline Suomen Kulttuurirahasto & Professori Vä̈nö Salmisen muotokuva \\
\hline Helsingin Yliopiston museo & Professori Matti Äyräpään muotokuva \\
\hline Kansallisgalleria & Professori E.N.Setälän muotokuva (A II 942) \\
\hline Yksityiskokoelma & Apiloita maljakossa \\
\hline Kansallisgalleria & Syysmaisema (A-2002-586) \\
\hline Serlachius Museot & Tohtori E. W. Lybeckin muotokuva (2010) \\
\hline Yksityiskokoelma & Lönnrot ja runonlaulajat \\
\hline Yksityiskokoelma & Phyllis Sjöströmin muotokuva \\
\hline Gallen-Kallela Museo & Vainovalkeat (GKM-7376) \\
\hline Gallen-Kallela Museo & Rantamaisema Tarvaspäästä (GKM-7377) \\
\hline Yksityiskokoelma & Jäiden lähtö Ruovedellä \\
\hline Yksityiskokoelma & Rantamaisema \\
\hline Yksityiskokoelma & Kolme kreiviä laivalla \\
\hline Yksityiskokoelma & Uutisia lukeva Kirsti \\
\hline Yksityiskokoelma & Kirsti soittaa selloa \\
\hline Kustannusosakeyhtio Otava Oy & Eino Leinon muotokuva \\
\hline Rauman taidemuseo & Talvimaisema \\
\hline Yksityiskokoelma & Talvi-ilta Kalelassa \\
\hline Rauman taidemuseo & Jäiden lähtö \\
\hline Gallen-Kallela Museo & Ryijy-aihe (GKM-308) \\
\hline Kansallisgalleria & Eric O.W.Ehrnströmin muotokuva (A III 2152) \\
\hline Yksityiskokoelma & Linuddin ikkunasta \\
\hline Gallen-Kallela Museo & Ensilumi Ruovedellä (GKM-7378) \\
\hline Serlachius Museot & Kalliomaisema New Mexicosta (288) \\
\hline Serlachius Museot & Mrs Margaret Lippo Hecht ja tytär Margareta, kaksoismuotokuvaluonnos (618) \\
\hline Gallen-Kallela Museo & Mrs Hecht, muotokuvaluonnos (GKM-313) \\
\hline Gallen-Kallela Museo & Näköala ikkunasta Chicagossa (GKM-314) \\
\hline Yksityiskokoelma & Muotokuvaluonnos \\
\hline Kansallisgalleria & Portti Taosissa (A III 2156) \\
\hline Kansallisgalleria & Taoskoti auringossa (A III 2158) \\
\hline Kansallisgalleria & Taoskoti kuutamossa (A III 2157) \\
\hline Yksityiskokoelma & Näkymä Taos-vuorilta, hevosia \\
\hline Yksityiskokoelma & Näkymä Taos-vuorilta \\
\hline Yksityiskokoelma & Koti Taosissa \\
\hline
\end{tabular}

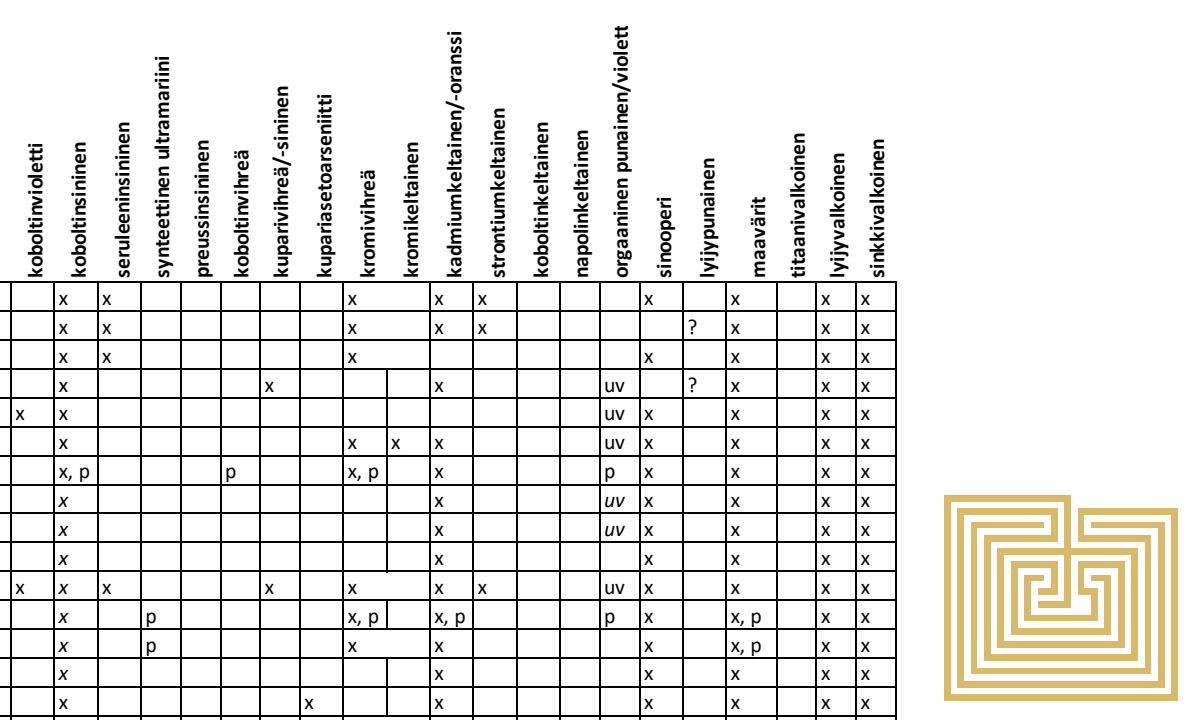


Taulukko 1 jatk.

omistaja
\begin{tabular}{|l|l|}
\hline Gallen-Kallela Museo & Heoksen nimi (inv. no.) \\
\hline Yksityiskokoelma & Näkymä ja lampaat (GKM-733) \\
\hline Kansallisgalleria & Vaja Taosvuorerilla (A III 2162) \\
\hline Kansallisgalleria & Taos-vuoret pilvien peitossa (A III 2161) \\
\hline Kansallisgalleria & Intiaani ratsain lumessa (A III 2160) \\
\hline Kansallisgalleria & Intiaani ratsain (A III 2159) \\
\hline Yksityiskokoelma & Penitentit ristejään kantaen \\
\hline Yksityiskokoelma & Taos portti ja kaksi lumessa ratsastavaa intiaania \\
\hline Serlachius Museot & Intiaaninainen New Mexicossa (289) \\
\hline Serlachius Museot & Piilipuu ja sininen lintu (290) \\
\hline Yksityiskokoelma & Mannerheimin muotokuna, luonnos \\
\hline Yksityiskokoelma & Mannerheimin muotokuvaluonnos \\
\hline Mannerheim Museo & Mannerheimin muotokuva \\
\hline Yksityiskokoelma & Alma von Christiersonin muotokuva \\
\hline Yksityiskokoelma & Piika ja sonni \\
\hline
\end{tabular}
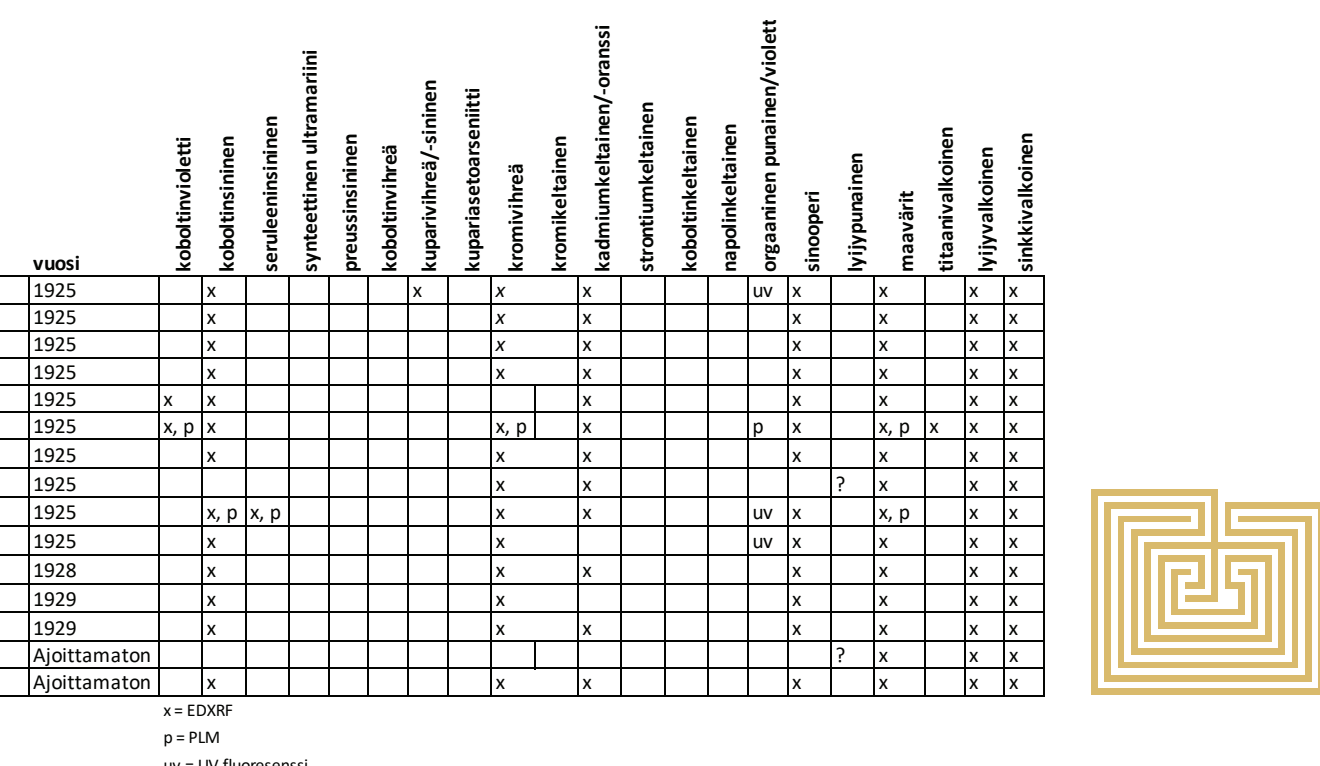

$p=$ PLM

$\mathrm{uv}=\mathrm{UV}$ fluoresenss 


\section{taulukko 2}

valmistaja

Syntons-Farben

Beckmann's Syntons-Farben

Beckmann's Syntons-Farben

Beckmann's Syntons-Farben

Beckmann's Syntons-Farben

Beckmann's Syntons-Farben

Bernhard Kahn \& Co

(Koiner Farben Fabrik)

Bernhard Kahn \& Co (Kölner Farben Fabrik)

Behrendt Farbe

Fritz Behrendt Farbe

Fritz Behrendt Farbe

Fritz Behrendt Farbe

Fritz Behrendt Farbe

\begin{tabular}{|l}
\hline Fritz Behrendt Farbe \\
\hline Fritz Behrendt Farbe \\
\hline
\end{tabular}

Fritz Behrendt Farbe

Becker

Wilh. Becker

Beckers Normalfärger $A B$

Beckers Normalfärger $A B$

Dr. Fr. Schoenfeld \& Co.

Dr. Fr. Schoenfeld \& Co.

Dr. Fr. Schoenfeld \& Co.

Dr. Fr. Schoenfeld \& Co.

Schönf.(epäselvä)

Schönf. (epäselvä)

v. Pereira's Temperafarbe

v. Pereira's Temperafarbe

v. Pereira's Temperafarbe

v. Pereira's Temperafarbe

v. Pereira's Temperafarbe

v. Pereira's Temperafarbe

v. Pereira's Temperafarbe nimi

\begin{tabular}{l} 
inv. no. \\
\hline GKM-4399
\end{tabular}

GKM-4399

GKM-4399

GKM-4399

GKM-4399

GKM-?

GKM-4274

GKM-5207

GKM-4399

Münchener lack

vaalean sininen

kobaltgrün

hell

\begin{tabular}{l|l} 
Behrendtgrün & helllstes \\
\hline
\end{tabular}

\begin{tabular}{l|l} 
Behrendtgrün & hell \\
\hline
\end{tabular}

Behrendtgrün

oranssi

Elfenbeinschwarz

Caput mortuum deep

Kremsenhv.

Kromoxidgrönt

Terra di Sienna

Ultramarinblåt

Cobaltblue

dunke

\begin{tabular}{l|l|l|}
\hline Lichter Ocker & No.1 & GKM-4399 \\
\hline
\end{tabular}

Umbra (Cyprische) raw

Elfenbeinschw.

Goldocker

Terra di Sienna nat. fell.

\begin{tabular}{l|l} 
Ultramarin & hell \\
\hline
\end{tabular}

Kraplakk (Garance) rosa

ei saa selvää

ei saa selvää

GKM-4272

GKM-4272

GKM- 898

GKM-898

GKM-898

GKM-898

GKM-6306

GKM-6306

GKM-4399

GKM-6306

GKM-912

GKM-6306

GKM-4399

GKM-4399

GKM-4399

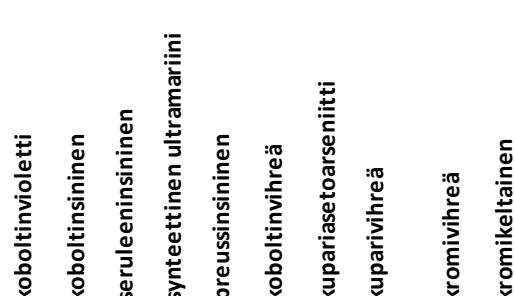

ํㅐㄲ

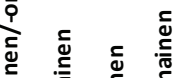

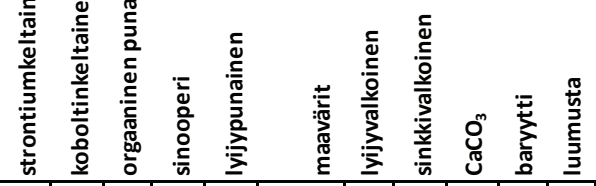
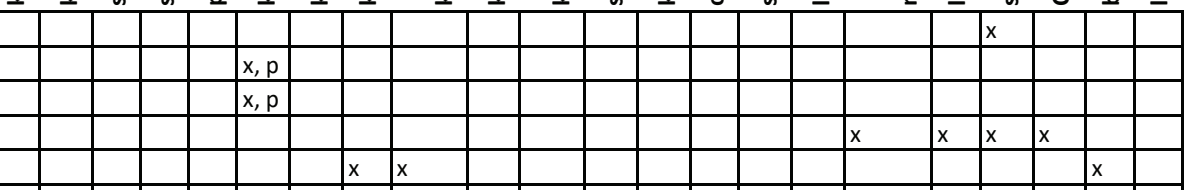

\begin{tabular}{llll|l|l|l|l|l|}
\hline & & & & & & & & \\
\hline & & & & & & & &
\end{tabular}

$x, x$

\begin{tabular}{l|l|l|}
\hline$x, p$ & & $p$ \\
\hline
\end{tabular}

GKM-?

$x=$ EDXRF

$p=P L M$

$\mathrm{uv}=\mathrm{UV}$ fluoresenssi

\begin{tabular}{ll|l|l|l|l} 
& & & & & \\
* hydratoitu kromioksidivihreä
\end{tabular}

** hydratoidun kromioksidivihreän lisäksi kromioksidivihreäa

עTahiti 1/2020 | Artikkelit | Tikkala \& Hornytzkyj: Akseli Gallen-Kallelan väriainepaletti 
taulukko 2 jatk.

valmistaja

nimi

Whillin

要

\begin{tabular}{l} 
v. Pereira's Temperafarbe \\
\hline v. Pereira's Mediumfarbe \\
v.Pereira's Nedfatbe
\end{tabular}

Casslerbraun

inv. no.

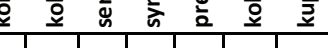

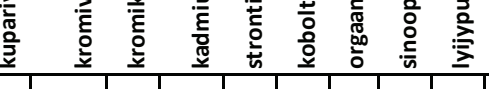

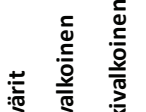

v.Pereira's $s$ Mediumfarbe

cerusa

\begin{tabular}{|l|l}
\hline Pereira's Neufarbe & demi ombre neu \\
\hline Epäselvä - & Arane \\
\hline
\end{tabular}

\begin{tabular}{|l|l|}
\hline Epäselvä & Alizarine-Madder \\
\hline Marine blue (seru..) \\
\hline
\end{tabular}

\begin{tabular}{|l|l|l|}
\hline päselvă & Marine blue (seru...) & \\
\hline
\end{tabular}

\begin{tabular}{|l|l|l|l|} 
& & & \\
\hline Epäselvä & org pun.4399 & ilman etikettiä & GKM-4399 \\
\hline
\end{tabular}

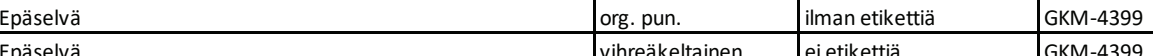

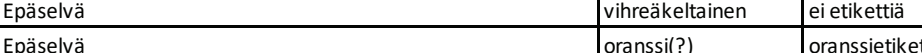

\begin{tabular}{ll|l|}
\hline oranssi(?) & oranssietiketti & GKM-4399 \\
\hline
\end{tabular}

H. Schmincke \&Co

\begin{tabular}{l|l|l}
\hline Kobaltblau & hell & GKM-898
\end{tabular}

H. Schmincke \&CO

H. Schmincke \&CO

Kobaltblay

H. Schmincke \&Co

\begin{tabular}{l|l|l|l}
\hline BKM-4399 & GKond'Argent & \\
\hline
\end{tabular}

\begin{tabular}{|l|l|}
\hline & Kremserweiß nol \\
\hline H. Schmincke \&Co & Zninwir \\
\hline H. Schinge
\end{tabular}

\begin{tabular}{l|l}
\hline & Zinkweiß no2 \\
\hline
\end{tabular}

Zinkweiß no2

H. Schmincke \&CO

Kadmiumgelb 2. hell

H. Schmincke \&CO

Siena

H. Schmincke \&Co

\begin{tabular}{l|l} 
& gebrant \\
\hline Terra di Sienna & gebrat \\
\hline
\end{tabular}

H. Schmincke \&CO

\begin{tabular}{|l|l|}
\hline Lichter ocker 1 & nat. \\
\hline
\end{tabular}

\begin{tabular}{|l|l|l} 
H. Schmincke \&Co & Goldocker & gebrant \\
\hline & Grüne verde & gebrant
\end{tabular}

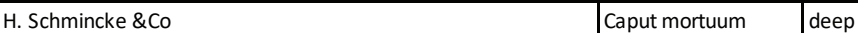

\begin{tabular}{l|l} 
Caput mortuum & deep \\
\hline
\end{tabular}

H. Schmincke \&CO

\begin{tabular}{l|l} 
Blaugrünoxyd & no 103 \\
\hline
\end{tabular}

\begin{tabular}{|l|l}
\hline H. Schmincke \&Co & Elfenbeinschwarz \\
\hline Schn & Eisaa senval \\
\hline
\end{tabular}

\begin{tabular}{|l|l}
\hline Schm (ei saa selvää) & Violet cob. \\
\hline H.Schmincke & Zinnoberrot \\
\hline
\end{tabular}

-

\begin{tabular}{|l|l|l}
\hline$G K M-4399$ \\
\hline$G K M-898$ \\
\hline$G K M-898$
\end{tabular}

GKM-898

GKM-4399

GKM-4399

GKM-898

\begin{tabular}{ll}
\hline GKM-898 \\
\hline GKM-898
\end{tabular}

GKM-898

GKM-898

GKM-6306

GKM-912

GKM-898

GKM-4273
GKM-912

GKM-912

$x=$ EDXRF

uv $=$ UV fluoresenssi

עTahiti 1/2020 | Artikkelit | Tikkala \& Hornytzkyj: Akseli Gallen-Kallelan väriainepaletti 


\section{taulukko 2 jatk.}

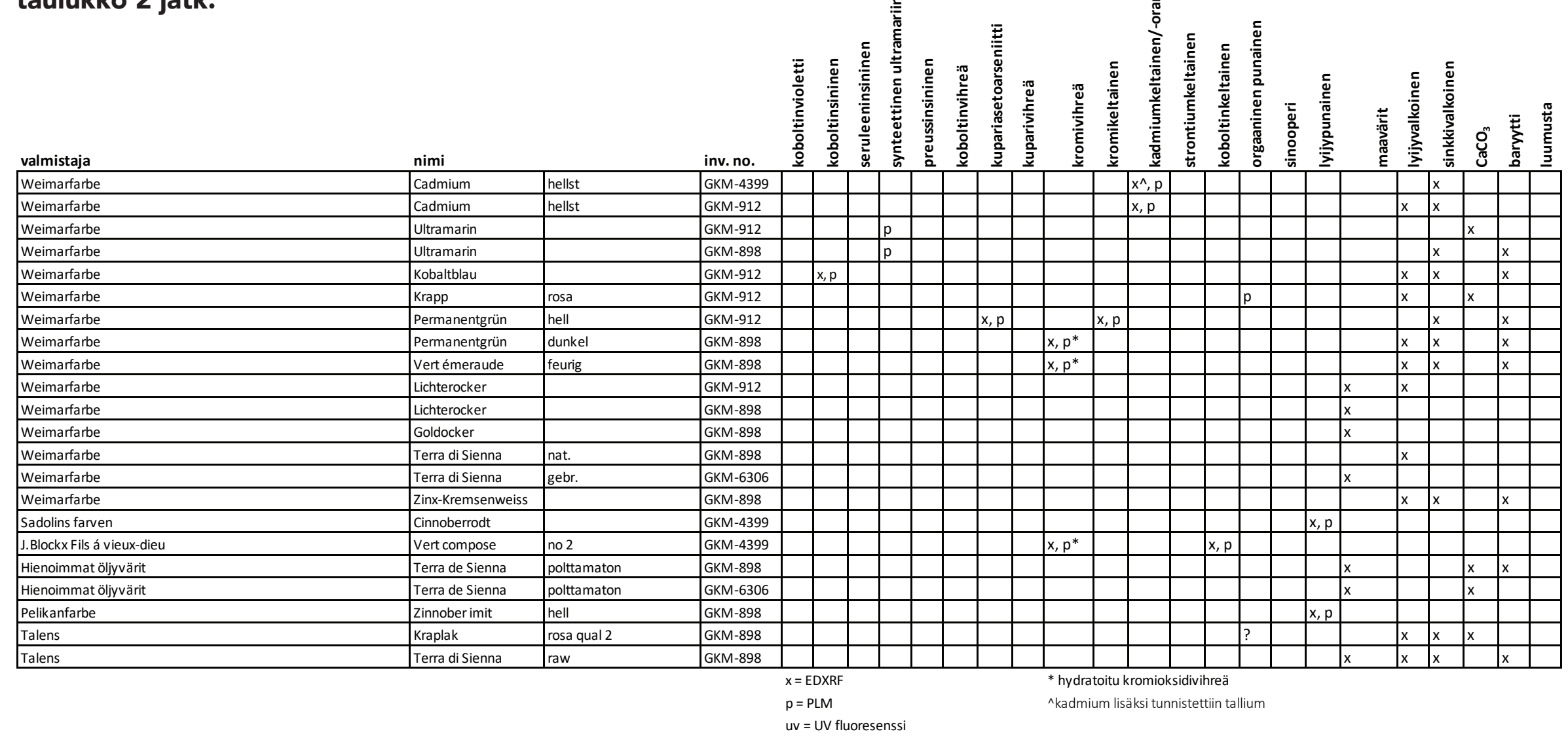

